\title{
Macrolichen and calicioid flora of Forillon National Park, Quebec, Canada: the big and little lichens and their associates
}

\author{
by
}

Hayley Anne Paquette

A thesis submitted to the Faculty of Graduate and Postdoctoral Affairs in partial fulfillment of the requirements for the degree of

Master of Science

in

Biology

Carleton University

Ottawa, Ontario

(C) 2019, Hayley Anne Paquette 


\section{Dedication}

To Niels, thanks for not getting involved. 


\begin{abstract}
The lichen biota of North America is poorly documented in many areas, including many of Canada's national parks. For example, Forillon National Park in Quebec, Canada had no previously published accounts of its lichen biota. Therefore, we conducted a comprehensive survey of macrolichens and calicioid lichens and fungi in the park to establish a baseline species list. We discovered 170 taxa in the park (169 species and two subspecies in 48 genera). One species, Melanohalea exasperata, is a first record for Canada; three species, Calicium denigratum, Sclerophora coniophaea, and Scytinium teretiusculum, are new provincial records; two species; Chaenothecopsis oregana and Parmelia fertilis, have notable range extensions; and one species, Sclerophora peronella, is listed as 'special concern' under Schedule 1 of the Canadian Species at Risk Act. We present annotated checklists and identification keys to the macrolichen and calicioid species of Forillon National Park.
\end{abstract}




\section{Acknowledgements}

No one finds themselves in any place, especially a positive one, entirely of their own doing. Here, I thank a few of the people to whom my successes over the past two years may be credited:

To my advisors, Drs. R.T. McMullin and M.L. Smith; you have given me both support and freedom throughout this project for which I am thankful. Troy, for this opportunity and your enthusiasm, guidance and friendship, I am infinitely grateful. You have ruined hiking for everyone I know, thank you. Myron, thank you for supporting and encouraging this project, and patiently answering all my neurotic questions.

To Drs. L. Fahrig and L. Gillespie, your generosity of time, sharing of knowledge (during and outside of scheduled committee meetings) and your support for this unique project is greatly appreciated.

To Drs. I. Brodo, S. Selva, J. Lendemer, T. Ahti, I. Kärnfelt and Ms. F. Anderson for their input on specimen identification and enthusiasm to share their expertise. J. Gagnon, for sharing your insights on the lichens of Quebec and microhabitats unique to the Gaspé region. C. Freebury, for your generosity of spirit and literature, I have used the books almost every day over the past two years.

To my forest bouncers, H. Beaugrand, N. van Miltenburg and L. Weir, your company and assistance in matters of fieldwork and life are irreplaceable.

To my friends and family who have supported, encouraged, inspired and challenged me, now and throughout my life, there is not enough room here to communicate my gratitude. A. and D. Paquette; C. and H. Paquette; L. Boustead; S. Brenner; B. and E. van Miltenburg; M. Thorburn and L. Calcagno; J. Bestfather; and C. Schmalz. Please forgive me for not naming all of you.

To the staff at Forillon National Park, particularly D. Sigouin, M. Côté, and J-D. Dupuis; for your support and encouragement for this project. I am particularly indebted for the provision of a campsite for the duration of my fieldwork, maps, space to dry and store specimens, lending of other equipment and sharing of insights into the unique and wonderful ecology of Forillon.

Financial support for this project was provided by the Canadian Museum of Nature through the Scientific Training Program. 


\section{Co-Authors}

\section{Chapter 2: Macrolichens of Forillon National Park, Quebec, Canada.}

Hayley A. Paquette and R. Troy McMullin.

H.P. and R.T.M. conceived of the project. H.P planned and carried out the fieldwork, including obtaining a collection permit from Parks Canada; processed and identified or verified all specimens for this project, except where otherwise noted; and prepared the manuscript with support from R.T.M. R.T.M. supervised the project and verified specimens as needed. Both co-authors discussed the results and contributed to the final manuscript. This manuscript has been submitted to Northeastern Naturalist.

\section{Chapter 3: The calicioids of Forillon National Park, Quebec, Canada.}

Hayley A. Paquette, Niels B. van Miltenburg, Steven B. Selva and R. Troy McMullin.

H.P. and R.T.M. conceived of the project. H.P. planned and carried out the fieldwork with the help of N.v.M.; applied for a collection permit from Parks Canada; processed and identified all specimens for this project, except H.A. Paquette 420 (CANL), which was determined by R.T.M.; and prepared the manuscript with support from R.T.M. N.v.M assisted with fieldwork and prepared the scanning electron microscope images of ascospores and the distribution maps for the manuscript. S.S. provided important verifications on difficult specimens. R.T.M. supervised the project and verified specimens as needed. All co-authors discussed the results and reviewed the final manuscript. This manuscript has been published in Opuscula Philolichenum. 


\section{Table of Contents}

Dedication ................................................................................................................................. ii

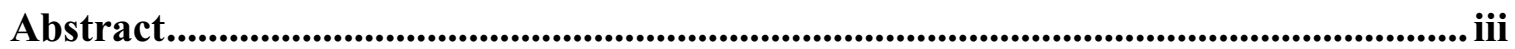

Acknowledgements .......................................................................................................................... iv

Co-Authors ......................................................................................................................................... v

Table of Contents .......................................................................................................................... vi

List of Tables ............................................................................................................ ix

List of Figures............................................................................................................................. $\mathrm{x}$

List of Appendices......................................................................................................................... xi

Chapter 1: Introduction ............................................................................................................. 12

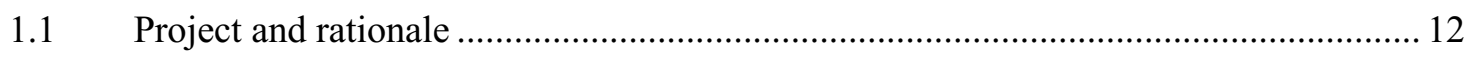

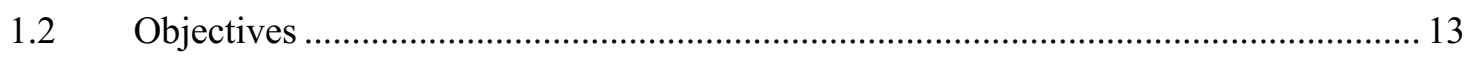

$1.3 \quad$ What is a lichen?

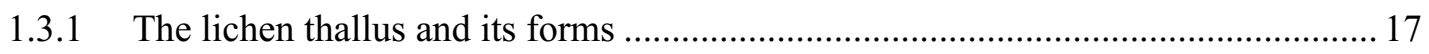

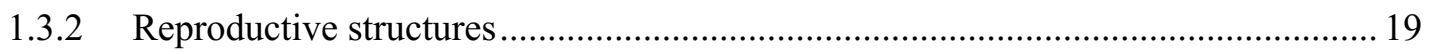

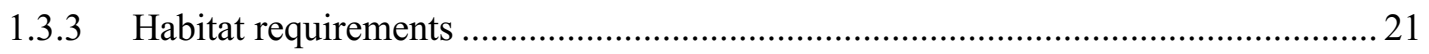

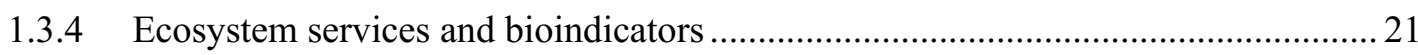

Chapter 2: Macrolichens of Forillon National Park, Quebec, Canada ...................... 23

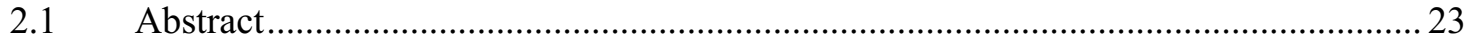

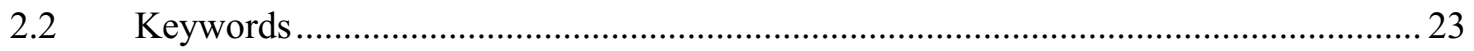

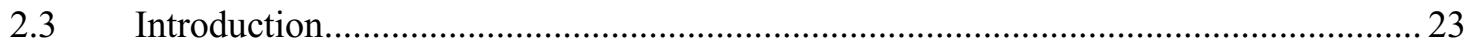

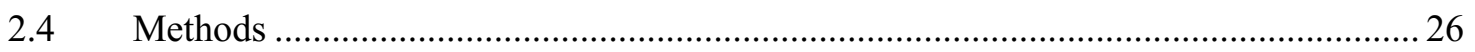

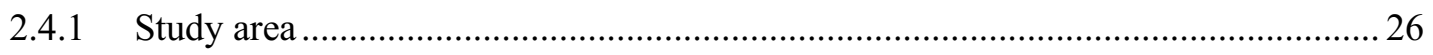

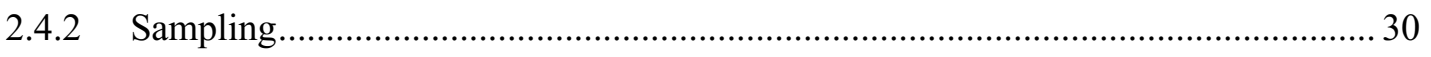

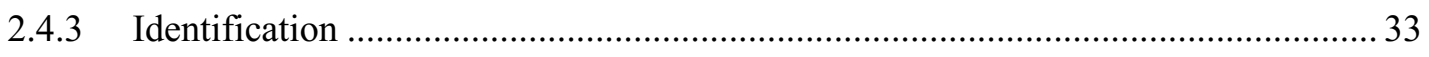




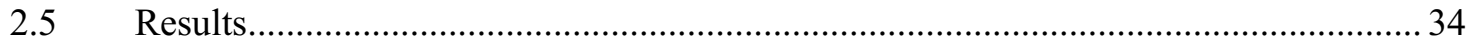

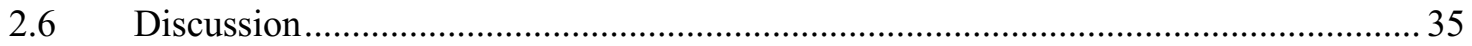

Chapter 3: The calicioids of Forillon National Park, Quebec, Canada ....................... 44

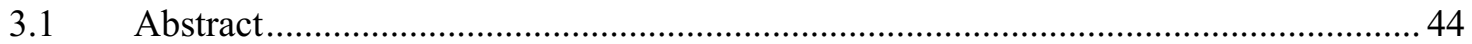

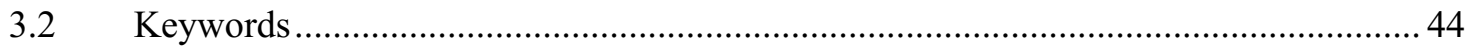

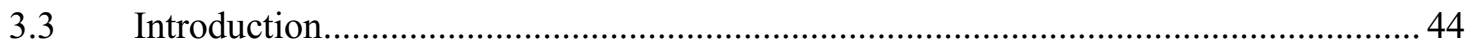

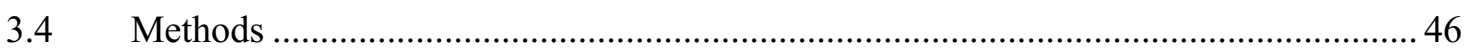

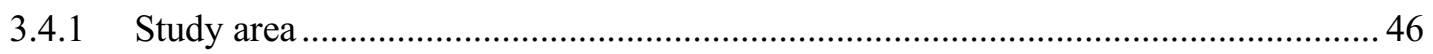

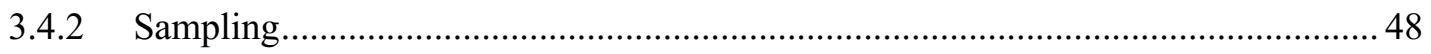

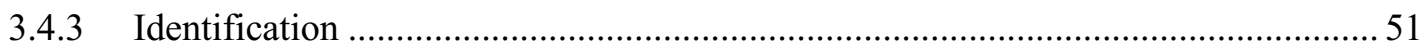

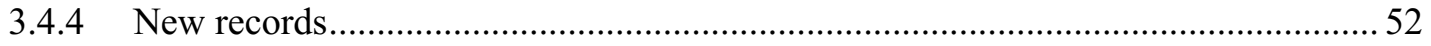

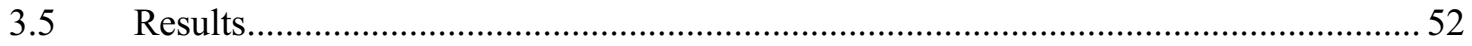

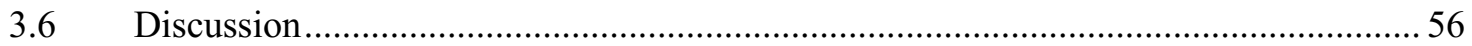

Chapter 4: Conclusions ............................................................................................................. 59

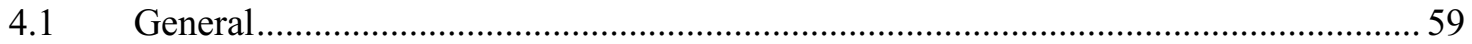

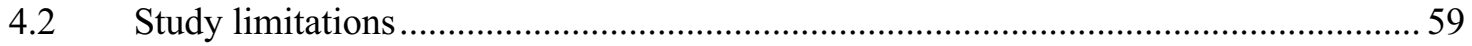

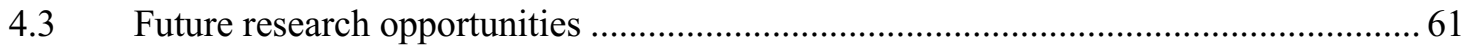

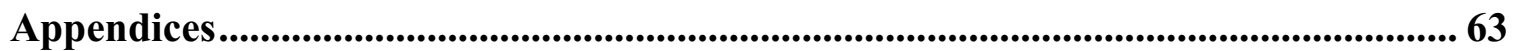

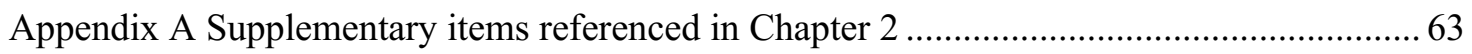

A.1 Location and habitat descriptions for the macrolichen collection sites in Forillon

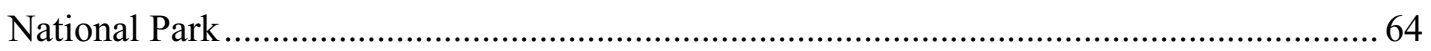

A.2 Annotated checklist of macrolichen species of Forillon National Park .................... 72

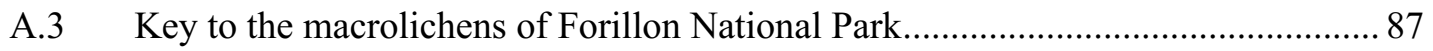

A.4 Subparaplectenchymatous cells in the proper exciple of Collema nigrescens....... 103 
A.5 Laminal apothecia of Tuckermanopsis sp. 1 (H.A. Paquette 635)

Appendix B Supplementary items referenced in Chapter 3

B.1 Global Positioning System coordinates of calicioid collection sites in Forillon

National Park

B.2 Annotated checklist of calicioid lichen and fungi species of Forillon National Park 108

B.3 Key to the calicioids of Forillon National Park

References.

117 


\section{List of Tables}

Table 2.1. Cyanolichens reported in Forillon. Reports based on herbarium vouchers verified by the authors are followed by an asterisk $(*)$....

Table A.1.1. Descriptions of the habitat and location of macrolichen collection sites in Forillon National Park

Table A.1.2. Global Positioning System coordinates of macrolichen collection sites in Forillon National Park .68

Table B.1.1. Global Positioning System coordinates of calicioid collection sites in Forillon National Park 


\section{List of Figures}

Figure 1.1. Location of collection sites and tracks from fieldwork in Forillon National Park

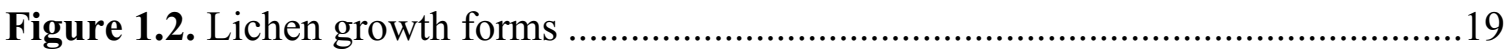

Figure 2.1. Location of the collection sites in Forillon National Park and of the study

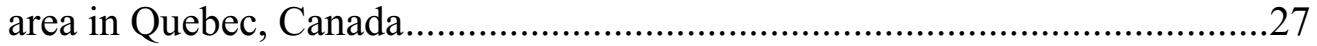

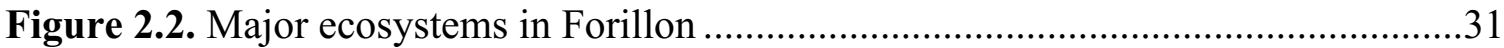

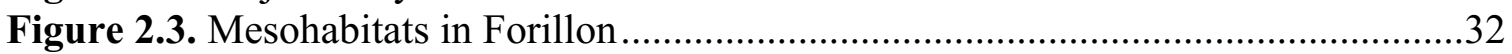

Figure 2.4. Macrolichen species of interest in Forillon ...............................................38

Figure 2.5. Macrolichen species of interest in Forillon, continued...................................39

Figure 2.6. Macrolichen species of interest in Forillon, continued....................................40

Figure 3.1. Location of the collection sites in Forillon National Park, and of the study area in Quebec, Canada...............................................................................4

Figure 3.2. Microhabitats of interest for calicioids in Forillon National Park..................50

Figure 3.3. Chaenothecopsis oregana (A-C from H. Paquette 420, CANL) ……...........53

Figure 3.4. Calicium denigratum (A-C from H. Paquette 527A, CANL) .........................54

Figure 3.5. Sclerophora coniophaea (A-C from H. Paquette 447, CANL) ......................55

Figure 3.6. Sclerophora peronella (A-C from H. Paquette 727, CANL).........................56

Figure A.4.1. The difference in cell shape in the proper exciple of two Collema species

Figure A.5.1. Laminal apothecia of Tuckermanopsis sp. 1 


\section{List of Appendices}

Appendix A Supplementary items referenced in Chapter 2

A.1 Location and habitat descriptions for macrolichen collection sites in Forillon

National Park 64

A.2 Annotated checklist of macrolichen species of Forillon National Park .................. 72

A.3 Key to the macrolichens of Forillon National Park .............................................. 87

A.4 Subparaplectenchymatous cells in the proper exciple of Collema nigrescens ...... 103

A.5 Laminal apothecia of Tuckermanopsis sp. 1 (H.A. Paquette 635)......................... 104

Appendix B Supplementary items referenced in Chapter 3 .................................. 105

B.1 Global Positioning System coordinates of calicioid collection sites in Forillon

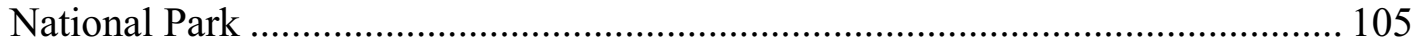

B.2 Annotated checklist of calicioid lichen and fungi species of Forillon National Park.. 


\section{Chapter 1: Introduction}

There is a low mist in the woods. It is a good day to study lichens.

(Henry David Thoreau 1851, p. 103)

\subsection{Project and rationale}

The purpose of my project was to complete a comprehensive floristic inventory of the macrolichens and calicioids of Forillon National Park (hereafter Forillon) in Quebec, Canada in order to establish a better understanding of lichen diversity in the park, thereby contributing to biogeographic knowledge of lichens in Canada and North America. I chose to focus on 1) macrolichens (foliose, fruticose and squamulose forms) as they are conspicuous taxa and typically grouped together (e.g., Hinds \& Hinds 2007, McCune \& Geiser 2009, Thomson 1984) and 2) calicioid lichens and fungi due to their considerable value to conservation management and monitoring (Goward \& Arsenault 2018, Hardman et al. 2017, McMullin et al. 2008, Petersen et al. 2017, Selva 2003, Tibell 1992), and the lack of study they have received in North America.

Canada's national park system includes 46 national parks and national park reserves. Detailed lichen studies have only been published for five of these parks (Brodo et al. 2013; Freebury 2014; Gowan \& Brodo 1988; McMullin 2009, 2012; PiercyNormore et al. 2016). Five additional parks have some published information (Brodo \& Sloan 2005, Douglas \& Vitt 1976, Hoefs \& Thomson 1972, Hrapko \& La Roi 1978, John 1989, Lamb 1954, Piercy-Normore et al. 2016, Timoney \& Robinson 1992), but 36 (ca. $78 \%$ ) of these ecologically important areas have no published information on their lichen biota, including Forillon (CNALH 2019, Sigouin pers. comm.).

I expected Forillon to contain a rich lichen biota because of its high diversity of ecosystems and habitats (Government of Canada 2010, St-Amour 1985) and due to the 
lichen studies published for nearby parc national de la Gaspésie (hereafter PNG) (Dodge 1926, McMullin \& Dorin 2016, McMullin et al. 2017b, Sirois et al. 1988). In particular, McMullin et al. (2017b) recently reported 100 lichen and allied fungi species from PNG that were not only new to Quebec, 12 were also new to Canada, and six of those were new to North America.

\subsection{Objectives}

The objectives of my project were to:

1) survey the macrolichen species, including foliose, fruticose and squamulose forms, in all major ecosystems in the park and as many meso- and microhabitats as possible.

2) survey the calicioid lichen and fungi species in all major ecosystems in the park and as many mesohabitats as possible, with a particular focus on suitable microhabitats.

3) collect a voucher specimen of each species and deposit it in a public herbarium. 4) build dichotomous keys for all species reported from the park, one for macrolichens and one for calicioids.

5) highlight and discuss species of interest.

These objectives are realized in Chapter 2: Macrolichens of Forillon National Park, Quebec, Canada, and Chapter 3: The calicioids of Forillon National Park, Quebec, Canada. I spent 39 days between 2017 and 2018 examining Forillon for lichens. I followed the Floristic Habitat Sampling method described and evaluated by Newmaster et al. (2005). This method is frequently used by lichenologists to conduct lichen inventories (e.g., McMullin \& Arsenault 2016, McMullin \& Lendemer 2016, Selva 2013), as Newmaster et al. (2005) found it captures cryptogam diversity more thoroughly 
than plot sampling methods. Floristic Habitat Sampling uses habitats as the sampling unit, focusing on meso- and microhabitats specifically (Newmaster et al. 2005). Mesohabitats are physiognomic (e.g., Thuja occidentalis forest) or physiographic (e.g., exposed calcareous cliffs) elements of a landscape; in the case of forested landscapes, they can be broken into dominant (e.g., different stand types) and restricted (e.g., cliffs) mesohabitats (Newmaster et al. 2005). The smallest landscape unit is a microhabitat (Newmaster et al. 2005), for example snags, crevices in rocks or crevices in exposed ditchbanks. I reviewed provincial and park vegetation maps and the park managment plan (Government of Canada 2010) and interviewed park staff to establish what the main ecosystem types in the park were (i.e., the dominant mesohabitats with respect to the forested areas). I examined multiple sites within each major ecosystem and as many meso- and microhabitats as possible with those ecosystems. The diversity of habitats I sampled from can be seen in Fig. 2.1 (Chapter 2). I continued investigations in each major ecosystem type until new species discovery became infrequent. I collected over 500 specimens (Fig. 1.1 and Appendices A.1 and B.2) across all major ecosystems and as many meso- and microhabitas as possible in the park (Figs. 2.2, 2.3 and 3.2). Each of the central chapters presents detailed methodology, results and conclusions. 


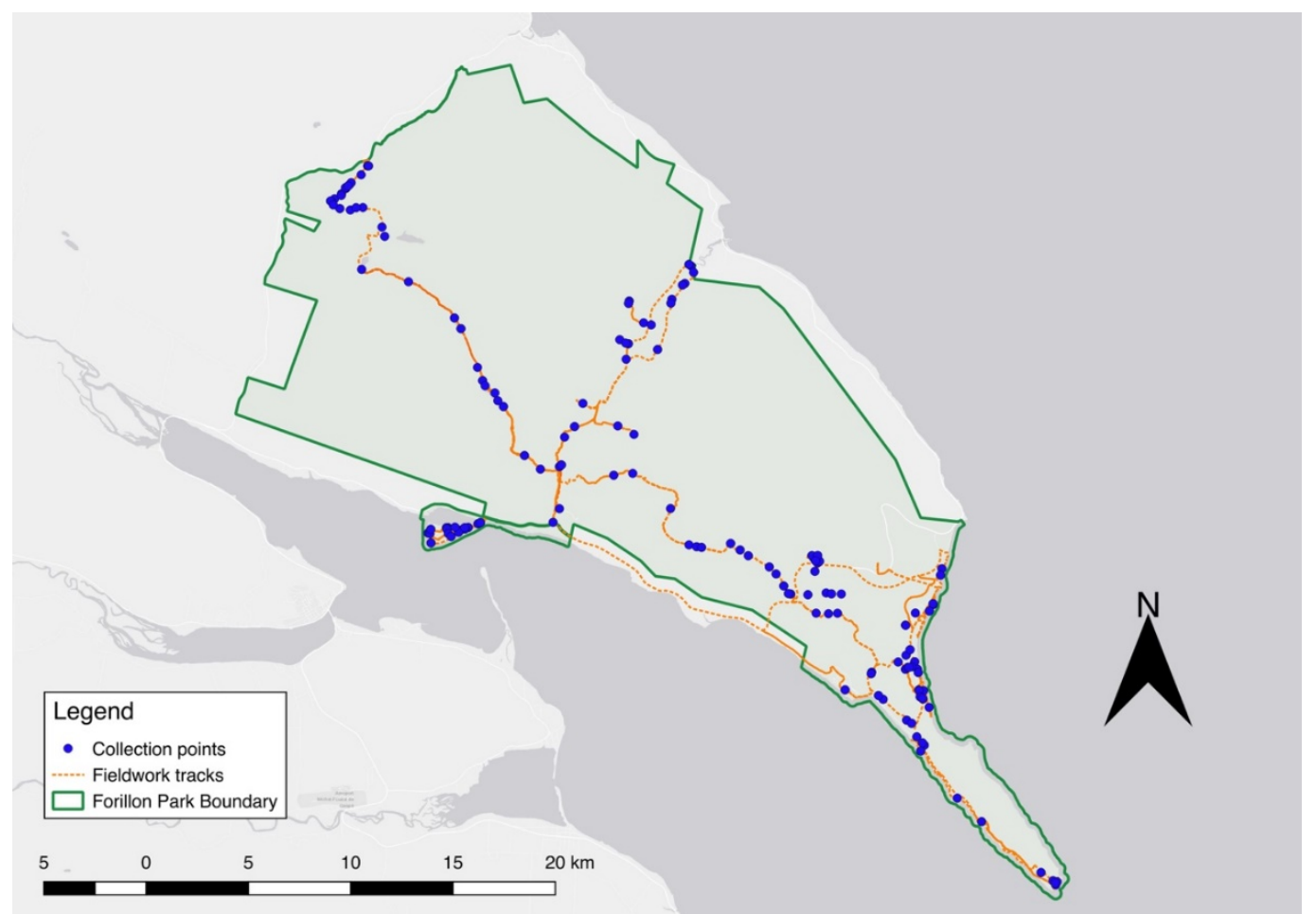

Figure 1.1. Location of all collection sites and tracks in Forillon National Park. Map created using QGIS (QGIS Development Team 2019) and presented in NAD83.

My study expands the biogeographic understanding of macrolichens and calicioid lichens and fungi in the Gaspé and the northern Appalachians, and more broadly in Canada and North America. I also establish a baseline from which future monitoring can identify changes in species presence/absence. I provide practical tools as well, the dichotomous keys (Appendices A.3 and B.3) for identifying the macrolichens and calicioids in the park. As well as images of some taxonomically relevant characters (e.g., Figs. 3.3, 3.4, 3.5, 3.6, and A.4). These resources can aid, and hopefully promote, additional study and conservation of lichens in Forillon and eastern Canada.

\subsection{What is a lichen?}

Lichens are a composite of at least two organisms, a fungus (mycobiont) and an algae, cyanobacteria, or both (photobionts) (Nash 2008). The mycobiont forms the body (thallus) of the lichen, enveloping the photobiont in hyphae (Nash 2008). The 
photosynthesizing partner (photobiont), provides carbohydrates to the heterotrophic mycobiont; other requisite minerals and nutrients are obtained atmospherically or from precipitation and water that washes over the lichen (Nash 2008, Nieboer et al. 1978). Over $20 \%$ of fungal species are lichenized, illustrating the success of this relationship (Hawksworth et al. 1995). The dualistic nature of lichens was first recognized by Schwendener (1867) and, despite the persisting questions regarding the relationship between mycobiont and photobiont that are beyond the scope of this project, it is commonly accepted as a symbiotic one (Brodo et al. 2001, Nash 2008, Smith \& Douglas 1987).

Lichens are cryptogams (spore producers) that are classified with fungi (Hale 1974, Nash 2008). Globally, approximately 17,500 species of lichen have been named (Lumbsch et al. 2011) and new species are described regularly (e.g. Allen \& Lendemer 2015a, Allen \& McMullin 2015, Anderson Stewart et al. 2018, Lendemer et al. 2019). Lichens have a panoply of physical forms, from leafy and dorsiventral to pendant and filamentous or shrubby and stalk-forming, and even spreading crusts and minute, pinlike stalks. Their range of reproductive modes is also varied, with at least 22 potential strategies spanning sexual, asexual and potentially parasexual processes (Tripp \& Lendemer 2018). They colonize a variety of substrates, including: rocks, tree bark and bare wood of coniferous and deciduous trees, decomposing wood, sand, humus, soil, moss, other lichens, and human-made structures of stone, cement, wood and plastic (Brodo et al. 2001, Nash 2008). They inhabit virtually all terrestrial ecosystems, from the north to the south poles (Brodo et al. 2001; Malcolm \& Galloway 1997; Purvis et al. 1985; Thomson 1984, 1997). The widespread occurrence of lichens and their unique 
physiology also make them useful indicators for environmental monitoring (Henderson 2000).

\subsubsection{The lichen thallus and its forms}

Lichen thalli are composed of fungal hyphae and algal and/or cyanobacterial cells (Hale 1974, Nash 2008). The mycobiont, with few exceptions, controls the appearance of the lichen thallus (Hale 1974, Nash 2008). The most basic structural components of a lichen thallus are the medulla, a loosely woven organization of hyphae where the photobiont is located; and the cortex, a compressed, gelatinized outer layer of hyphae enveloping the medulla (Hale 1974, Nash 2008). Additional features of the thallus important to morphology are reproductive structures; these are discussed in section 1.3.2.

Lichen thalli exhibit a wide variety of structural forms and colours (Nash 2008, Smith 1921). These forms are typically organized into three morphological groupings: crustose, foliose, and fruticose (Hale 1974, Nash 2008). However, sub-groupings within these broad forms are acknowledged; for example, calicioid lichens are sometimes treated as fruticose due to their stalked apothecia (Goward 1999), or as a fourth grouping of their own: calicioids or stubble lichens and fungi (Tibell 1999). In my study, I examined foliose and fruticose forms (macrolichens), and calicioid lichens and fungi.

Foliose lichens are characterized by a dorsiventral thallus, in essence a distinct top and bottom to the thallus (Gowan \& Brodo 1988, Hale 1974, Nash 2008). In most cases,

they are easily removed from their substrates (Gowan \& Brodo 1988). Within the foliose form, there is high variability in size, shape and stance (Fig. 1.2. A, B, E).

Fruticose lichens are stalked (ascending from their substrate) or pendant to shrubby (hanging or drooping downward from their substrate) (Gowan \& Brodo 1988, 
Nash 2008). They can be cupped, branched, hair-like, or shrubby (Fig. 1.2. C, D). They mostly have a similar cortex on all sides (i.e., not clearly dorsiventral) (Nash 2008).

Calicioids are characterized by their minute stalks (typically $<2 \mathrm{~mm}$ tall) topped with capitula (Selva 2003; Tibell 1996, 1999). The typical form is presented in Fig. 1.2. F. However, the calicioid form is described in detail in Chapter 3 with further examples given (Fig. 3.3. A, 3.4. A, 3.5. A, 3.6. A).

Crustose lichens (microlichens) are in close contact with their substrate, making it impossible to remove them without also removing some of their substrate (Brodo et al. 2001, Nash 2008). This form lacks a lower cortex and is attached to its substrate by fungal hyphae from the medulla (Hale 1974, Nash 2008). Although it is technically dorsiventral as in foliose lichens, it cannot be mistaken for this group due to its crust-like structure and lack of leafy lobes or squamules which characterize the latter form. I did not identify crustose lichens during my project. 


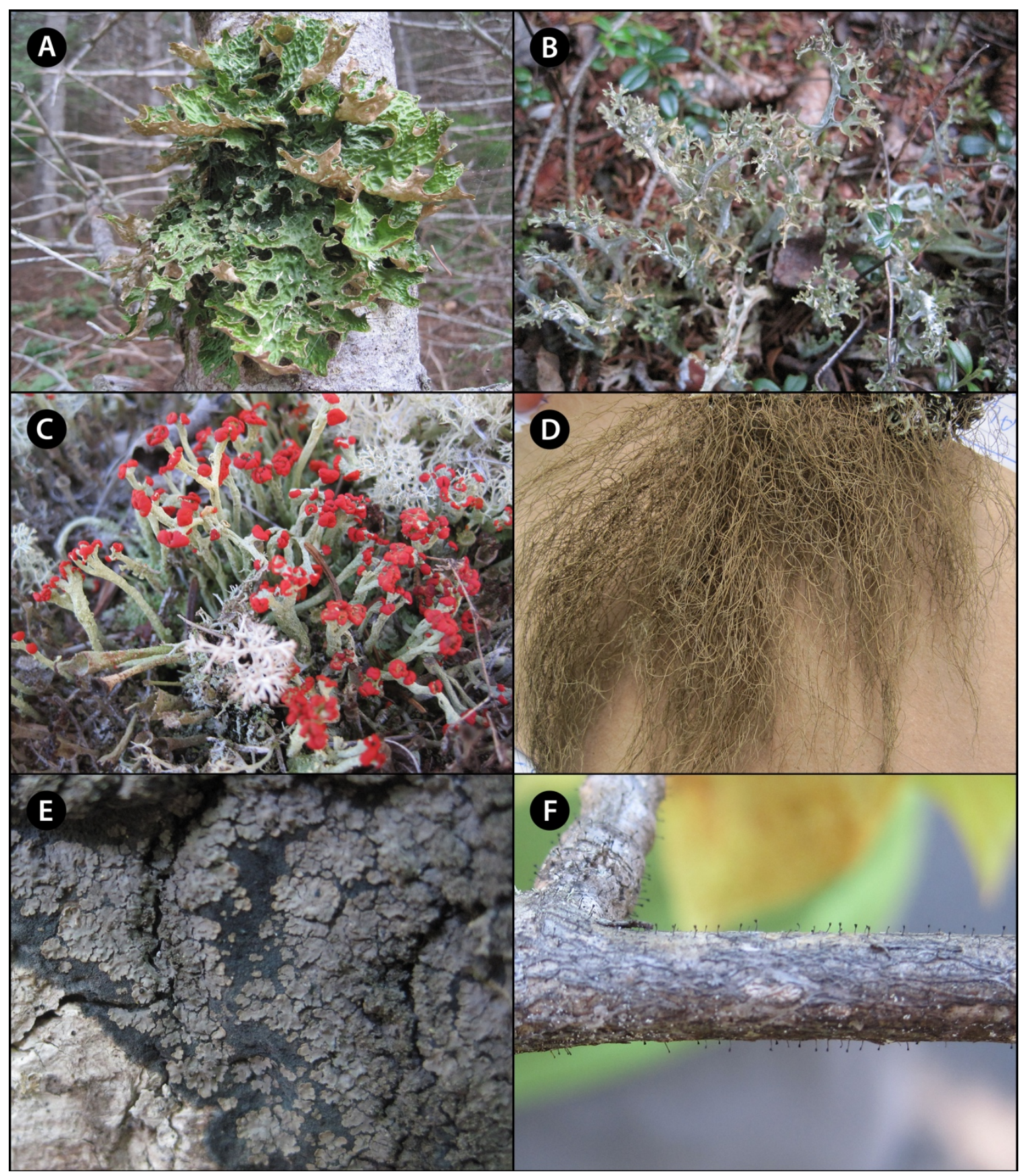

Figure 1.2. Lichen growth forms. A, Foliose, Lobaria pulmonaria. B, Erect foliose, Cetraria islandica. C, Stalked fruticose, Cladonia cristatella. D, Pendant fruticose, Bryoria pikei. E, Squamulose foliose, Parmeliella triptophylla. F, Calicioid, Phaeocalicium populneum.

\subsubsection{Reproductive structures}

Lichens use a diverse range of reproductive strategies (Nash 2008, Tripp \& Lendemer 2018). Tripp \& Lendemer (2018) gathered evidence from existing literature 
supporting the hypothesis that diversity of reproductive modes in lichens is far greater than in non-lichenized fungi. Those authors found support for 22 of 27 potential reproductive strategies in lichens. I will address lichen reproduction as it relates to morphology.

Lichens produce sexual or vegetative structures, and in many cases both (Nash 2008). In sexual reproduction the lichen produces fruiting bodies (apothecia or perithecia) that disperse spores (Brodo et al. 2001, Nash 2008). There are a variety of types of apothecia which can be used to disentangle the identity of a lichen (Brodo et al. 2001). For successful sexual reproduction, the appropriate fungal spore must settle on a suitable substrate, in a hospitable environment and encounter the correct photobiont (Nash 2008). Vegetative propagules are also produced by many lichens. They occur in various forms and are composed of both the photobiont and fungal elements of the lichen (Brodo et al. 2001, Hale 1974, Nash 2008). They contain the full complement of required components for a new lichen thallus to grow. The most prevalent vegetative structures are soredia and isidia. Soredia are round bundles of hyphae wrapped around photobiont cells and originate from the medulla (Hale 1974, Nash 2008). They appear powdery because they do not have a cortex. Isidia come in a wide variety of shapes and sizes. They are an extension of the thallus with a cortex and photobiont layer; the most common form is as cylindrical, or finger-like, projections (Hale 1974, Nash 2008). Vegetative propagules become detached from the main lichen thallus and begin to form a new lichen as long as they land on an appropriate substrate in a suitable habitat (Nash 2008). The shape, size, origin, colour and form of vegetative propagules like soredia and isidia can 
morphologically differentiate many lichen taxa (Brodo et al. 2001, Gowan \& Brodo 1988).

\subsubsection{Habitat requirements}

Most lichens species have narrow habitat requirements for sunlight, water/relative humidity, substrate, and mineral and nutrient availability (Nash 2008). For example, some lichens with algae as a photobiont can begin gas exchange at as little as $15-20 \%$ water content, while cyanolichens can require as much as $85-100 \%$ water content (Büdel and Lange 1991). Many lichens are also substrate specific; for example, some species of calicioid lichens only occur on specific species of trees (Selva 2013, 2014), some lichen species only occur on calcareous rocks or soil (Orange 2008), while others require particular minerals (e.g., Acarospora sinopica only grows on acidic rocks that are rich with iron) (Thomson 1997).

\subsubsection{Ecosystem services and bioindicators}

Lichens have a wide range of ecological functions (Allen \& Lendemer 2016b). They are involved in soil formation and nutrient cycling (Nieboer et al. 1978) and are used by some animals for food (Environment Canada 2012).

They are also useful in biological monitoring. As noted in section 1.3.3, lichens obtain nutrients from the atmosphere and precipitation that washes over them, so if there are pollutants in the air or rain they are taken in as well (Richardson 1992). Lichens have a range of sensitivity to these pollutants, which allows them to be used as monitors of air quality (Richardson 1992, Schram et al. 2015). Lichens have also been used to measure ecological continuity in forests (McMullin et al. 2008; Rose 1974, 1976; Selva 1999, 2003; Tibell 1992) and as predictors of the impacts of climate change on biodiversity 
(Allen \& Lendemer 2016a,b). The widespread distribution of lichens on earth and their sensitivity to environmental change make them a useful instrument for ecological monitoring. 


\section{Chapter 2: Macrolichens of Forillon National Park, Quebec, Canada}

Lichens abound everywhere, from the sea-shore to the tops of high mountains, where indeed the covering of perpetual snow is the only barrier to their advance.

(Annie Lorraine Smith 1921, p. 1)

\subsection{Abstract}

In Canada, detailed knowledge of the macrolichen biota in national parks is surprisingly sparse. Forillon National Park (Forillon) in Quebec, Canada is an example, as there are no previously published accounts of their lichens and only opportunistic collections are known. To fill this knowledge gap, we conducted a survey of the macrolichens in the park and reviewed past collections to establish a baseline list of species. We report 140 taxa from Forillon (139 species and two subspecies in 39 genera). Notable species include: Melanohalea exasperata, a first record for Canada; Scytinium teretiusculum, a first record for Quebec; Parmelia fertilis, a northern range extension; Hypogymnia subobscura, a species with an Arctic affinity; and Bryoria salazinica, Cladonia labradorica, and Leptogium acadiense, which are endemic to northeastern North America. We provide an annotated checklist and an identification key to the macrolichen species of Forillon.

\subsection{Keywords}

Appalachians, biogeography, cyanolichens, Gaspé Peninsula, biomonitoring.

\subsection{Introduction}

Understanding biodiversity across multiple spatial scales is integral to effective conservation management. The most fundamental component of this understanding is the 
establishment of baseline data for species diversity and distributions (Balmford et al. 2005, Environment Canada 1995, Giangrande 2003, Merinero et al. 2014, Monastersky 2014, Pimm et al. 1995, Powell et al. 1999, Scheidegger \& Werth 2009). The ecological, economic, cultural and spiritual value of biodiversity to human health and wellbeing is well-recognized (Costanza et al. 1997, Environment Canada 1995), but so are the extreme global declines in biodiversity (Balmford et al. 2005, Monastersky 2014). Despite the importance of and declines in biodiversity, much of the life on Earth is still unknown (Balmford et al. 2005, Giangrande 2003, Monastersky 2014, Pimm et al. 1995). In order to understand and monitor biodiversity, baseline data are essential, particularly for understanding the number of species, where they occur, and their status (e.g., rare or sensitive, etc.) (Balmford et al. 2005, Environment Canada 1995, Powell et al, 1999). The largest knowledge gaps in biodiversity are in smaller, less conspicuous groups, such as lichens.

Lichens are a diverse, ecologically significant, yet understudied group of organisms. They are composed of a fungus and one or more photosynthetic partners; either algae, cyanobacteria, or both (Nash 2008). They are also valuable tools for biomonitoring and evaluating conservation priorities. They are useful indicators of air quality (Richardson 1992, Henderson 2000), ecological integrity (McMullin \& Wiersma 2019, McMullin et al. 2008, Selva 2003), and the impacts of climate change on biodiversity (Allen \& Lendemer 2016a, b). Lichens can be used globally, as they inhabit virtually all terrestrial environments (Brodo et al. 2001); however, a lack of baseline knowledge limits the ability to monitor changes in species presence/absence in many parts of the world. As a result, lichens are frequently excluded from conservation 
management planning (Allen \& Lendemer 2015b). In Canada, there are 46 national parks and national park reserves. Detailed lichen studies have been completed at five of them (Brodo et al. 2013; Freebury 2014; Gowan \& Brodo 1988; McMullin 2009, 2012; PiercyNormore et al. 2016), and some collections have been reported from five additional parks (Brodo \& Sloan 2005, Douglas \& Vitt 1976, Hoefs \& Thomson 1972, Hrapko \& La Roi 1978, John 1989, Lamb 1954, Timoney \& Robinson 1992). Therefore, 36 of the 46 national parks and national park reserves have no or only incidental knowledge of their lichen biota.

One park with no previous published reports of its lichen biota is Forillon National Park (hereafter Forillon) on the eastern tip of the Gaspé Peninsula in Quebec, Canada. Forillon is in the northern Appalachians (Government of Canada 2010, StAmour 1985). Unlike the lichen diversity in the southern Appalachians, which has been well-studied (Allen \& Lendemer 2016b, Lendemer et al. 2013), the northern region is not well understood. In nearby parc national de la Gaspésie (hereafter PNG), some of the lichen diversity has been reported (Dodge 1926, McMullin \& Dorin 2016, McMullin et al. 2017b, Sirois et al. 1988), but much of it remains unreported (McMullin pers. comm.). In Forillon, opportunistic lichen collections have been made (CNALH 2019), but no detailed investigation of the lichen biota has been completed. Moreover, previous collections from the park are concentrated in the more disturbed high use areas, while the less disturbed and more difficult to access interior has not been explored. Therefore, encouraged by the findings of McMullin et al. (2017b) from PNG (they reported 100 lichen and allied fungi species new to Quebec, including 12 species new to Canada, six of which were new to North America), and by the high number of different ecosystems and 
habitats in the park (Government of Canada 2010, St-Amour 1985), we selected Forillon to examine for additional species of interest.

The purpose of our study is to better understand the lichen diversity in Forillon by conducting a detailed survey of the macrolichens in the park. Our objectives were to: 1) inventory the macrolichen species in all major ecosystems in the park, 2) collect a voucher specimen of each species and deposit it in a public herbarium, 3) build a dichotomous key for all species known from the park, and 4) highlight and discuss species of interest. Our findings expand the biogeographic understanding of macrolichens in the region and more broadly in Canada and North America. They also serve as a baseline from which future monitoring can detect changes in species presence/absence. We provide a dichotomous key to identify the macrolichens in Forillon, which we hope will foster further study, appreciation, and conservation of lichens in the park and eastern Canada.

\subsection{Methods}

\subsubsection{Study area}

Forillon is on the Gaspé Peninsula in the province of Quebec, Canada (Fig. 2.1). It is at the easternmost tip of the peninsula and is the terrestrial boundary of the Appalachian mountain range (Government of Canada 2010, St-Amour 1985). Forillon protects $240.8 \mathrm{~km}^{2}$ of terrestrial habitat, and an additional $4.4 \mathrm{~km}^{2}$ of marine coastline (Government of Canada 2010, St-Amour 1985). The maritime element in Forillon is part of the Gulf of St. Lawrence, which borders its northern boundary, and the Bay of Gaspé, which borders its southern boundary. Forillon is at the northern limit of the Acadian 
Forest Ecoregion (Selva 2013). In Canada, this portion of the Acadian Forest Ecoregion is referred to as the Atlantic Maritime Ecozone (Ecosystem Stratification Working Group 1995), or more precisely, the Northern Appalachian Ecoregion (Trombulak et al. 2008). The mean temperature, based on data from the nearest weather station (Cap Des Rosier) from $1981-2010$, is $-9.8^{\circ} \mathrm{C}$ in January and $16.2^{\circ} \mathrm{C}$ in July and the average annual precipitation is $1195.1 \mathrm{~mm}$, with approximately $74 \%$ as rain and $26 \%$ as snow (Environment Canada, 2019). Forillon's geology is primarily composed of sedimentary rocks, and the dominant rock types are limestone, shale and sandstone (St-Amour 1985).

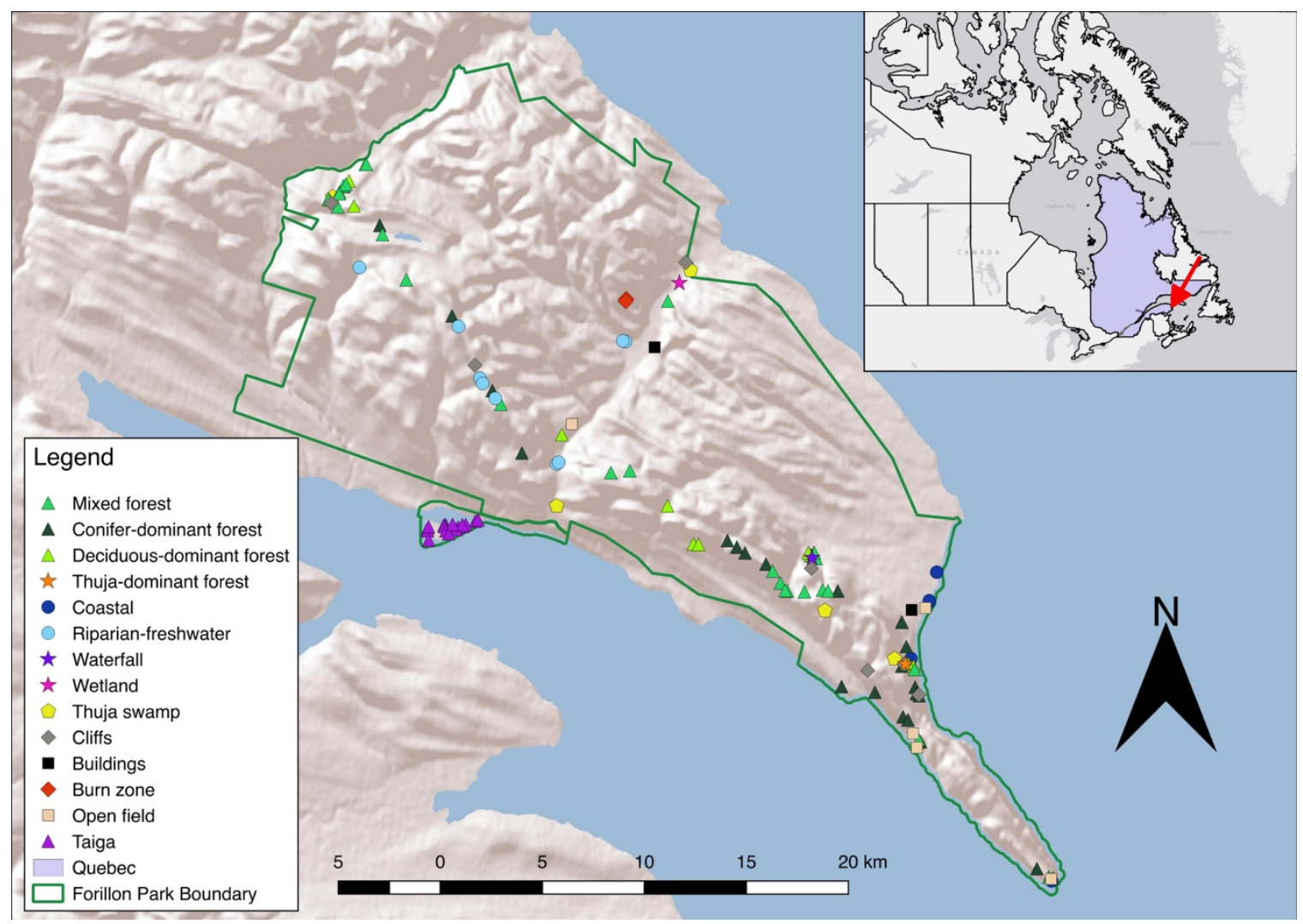

Figure 2.1. Location of the collection sites in Forillon National Park, and of the study area in Quebec, Canada (inset). Symbols and colours of points illustrate the diversity of habitats surveyed. The red arrow indicates the park's location within Quebec in Canada. Map is presented in NAD83.

Despite its relatively small size, Forillon contains a high diversity of habitats and a unique vascular plant flora (Government of Canada 2010, Parks Canada 1983, St- 
Amour 1985). The major ecosystems in the park are forest, aquatic, coastal and marine (Government of Canada 2010). The forest and terrestrial compoents of the coastal ecosystems are of primary relevance for macrolichen diversity. However, there are also relevant meso- and microhabitats in terrestrial parts of the aquatic ecosystems (e.g., riparian zones, shoreline rock outcrops, Thuja occidentalis swamps, and the surrounding banks of a waterfall) (Nash 2008). The dominant forest type in the park is boreal (e.g., along the ridges and on Penouille sandspit) with Abies balsamea, Picea glauca and $P$. mariana as the dominant species. However, in the valleys and at lower elevation zones, there is a mix of hardwood and softwood species, characteristic of the Acadian forest, including: Acer rubrum, A. saccharum, A. spicatum, Betula alleghaniensis, B. papyrifera, Populus balsamifera, P. tremuloides, and Thuja occidentalis. We examined habitats between zero and 494 metres. An additional habitat of interest is the taiga habitat on the Penouille sandspit, which extends into the Bay of Gaspé in the south sector of the park. This biome is unusual at such a low latitude and elevation (Government of Canada 2017). Within these major ecosystems, mesohabitats include: marine and freshwater shorelines, treed wetlands, rock cliffs and exposed rockfaces, talus slopes, waterfalls, old growth forest stands, and sandy clearings.

Forillon was designated a national park in 1970. Prior its national park status, the area had a rich cultural history. Indigenous people used the Anse-au-Griffon Valley as a thoroughfare across the peninsula between the Gulf of St. Lawrence and the Bay of Gaspé (Government of Canada 2010, 2017). On the Penouille sandspit, there is archaeological evidence of extensive tool-making and domestic activity by indigenous communities (St-Amour 1985). European exploitation began in the 1500's with seasonal 
fishing communities of French, Basque and Spanish origins (St-Amour 1985). It was not until the 1700 's that permanent settlements were established, driven by the arrival of English fishing companies (St-Amour 1985). In the 1800's, agriculture and logging were introduced to the Anse-au-Griffon Valley (St-Amour 1985). Due to the craggy topography of the peninsula these practices were restricted, though successful enough to draw in timber export companies by the 1900's (St-Amour 1985). After 1920, the arrival of rail, electricity and mail-order catalogues changed life for Forillon's inhabitants (StAmour 1985). After WWII, an airstrip was established on the Penouille sandspit and shortly thereafter, cottages along its coastline (NAPL 1966). Currently, only vague remnants of this infrastructure remain at Penouille.

Modern-day activities interacting with the park ecology include: a prescribed burn project to promote re-establishment of white pine and red oak stands; construction to reroute the section of Quebec route 132 (QC-132) that traverses the park which was completed in 2018 (Government of Canada 2018); and an overabundance of moose in the park (Sigouin et al. 2013).

In 2017, the park served 45,018 visitors (Government of Canada 2018). There are approximately $146 \mathrm{~km}$ of hiking and multi-use trails which include three backcountry campsites and two lean-to camping shelters (associated with the International Appalachian Trail network) (Government of Canada 2018). Forillon has three campgrounds: Cap Des Rosiers and Cap Bon Ami in North Sector, and Petit Gaspé in South Sector, which host 16 diversified accommodations (e.g., oTENTik and MicrOcube structures) and 352 semi-serviced campsites (Government of Canada 2017). 


\subsubsection{Sampling}

All major ecosystems, mesohabitats (including each major rock type and formation and all vegetation types) and as many microhabitats as possible were surveyed in Forillon by the first author (H.P.) in 2017 between August 19 and 28 and in 2018 between August 20 and September 23 following the Floristic Habitat Sampling (FHS) method described by Newmaster et al. (2005). Those authors found that FHS captures cryptogam diversity more effectively than sampling from smaller representative plots. This method of sampling is widely used by lichenologists for surveying lichens (e.g., Lendemer et al. 2013, McMullin 2018, McMullin \& Arsenault 2016, McMullin \& Wiersma 2017, McMullin et al. 2017b, Selva 1999). Within the dominant ecosystems (Fig. 2.2), we examined as many mesohabitats as possible. We surveyed each dominant mesohabitat within the forest ecosystem (i.e., stands of different species composition and age structure) and as many restricted mesohabitats as possible within those (e.g., aquatic features, exposed rock) (Fig. 2.3). We inspected applicable microhabitats throughout our survey, including stumps, snags, exposed roots, driftwood and exposed calcareous rock. Descriptions of the habitat and location of all collection sites are provided in Appendix A.1. We photographed all collections in the field using a Canon PowerShot Elph digital camera and georeferenced them using a Garmin GPSmap 60CSx handheld GPS navigator. We air dried specimens prior to transporting them to the Canadian Museum of Nature (CANL) in Gatineau, Quebec for identification. 


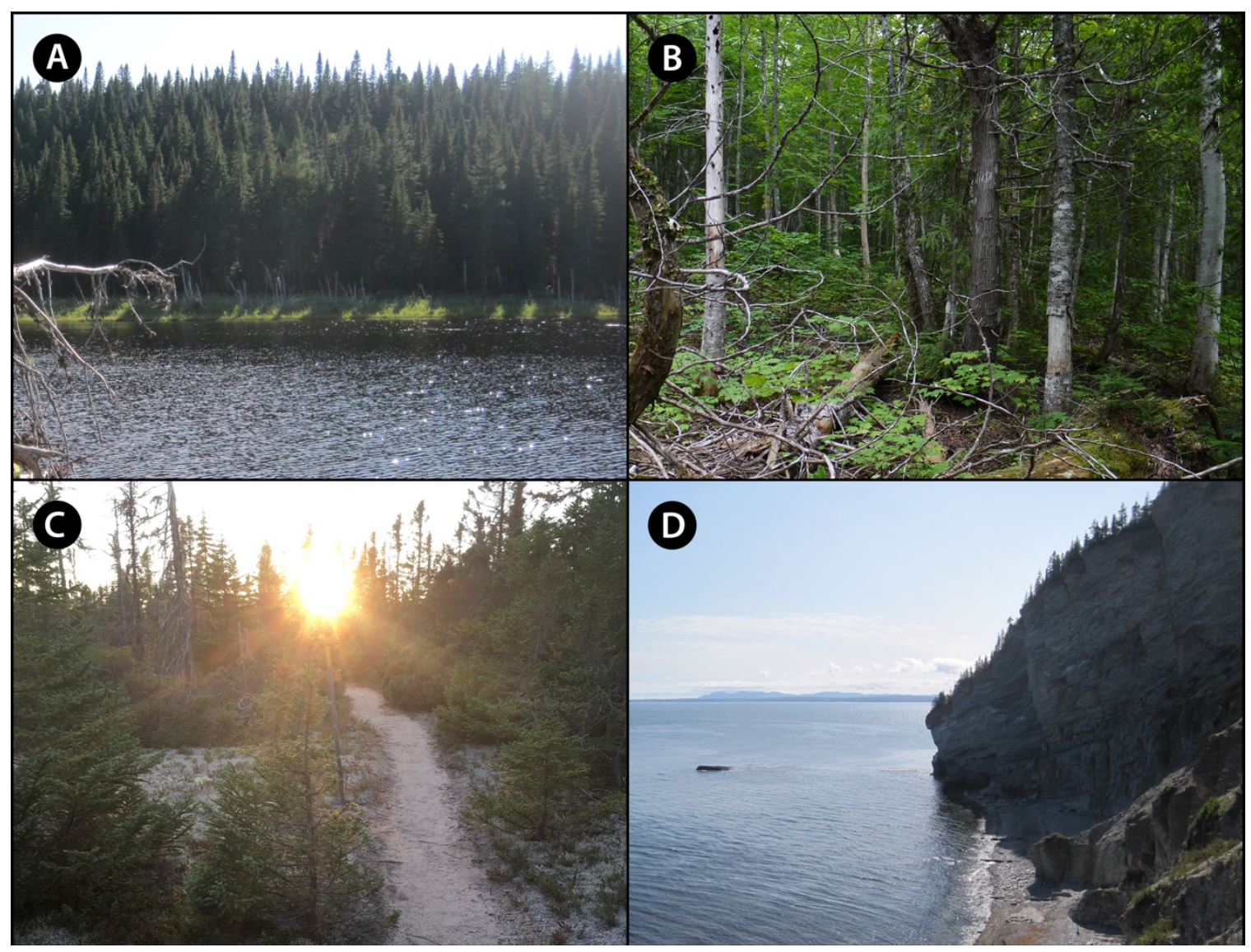

Figure 2.2. Major terrestrial ecosystems in Forillon. A, Conifer-dominant/Boreal forest. B, Mixed/Acadian forest. C, Taiga. D, Coastal. 


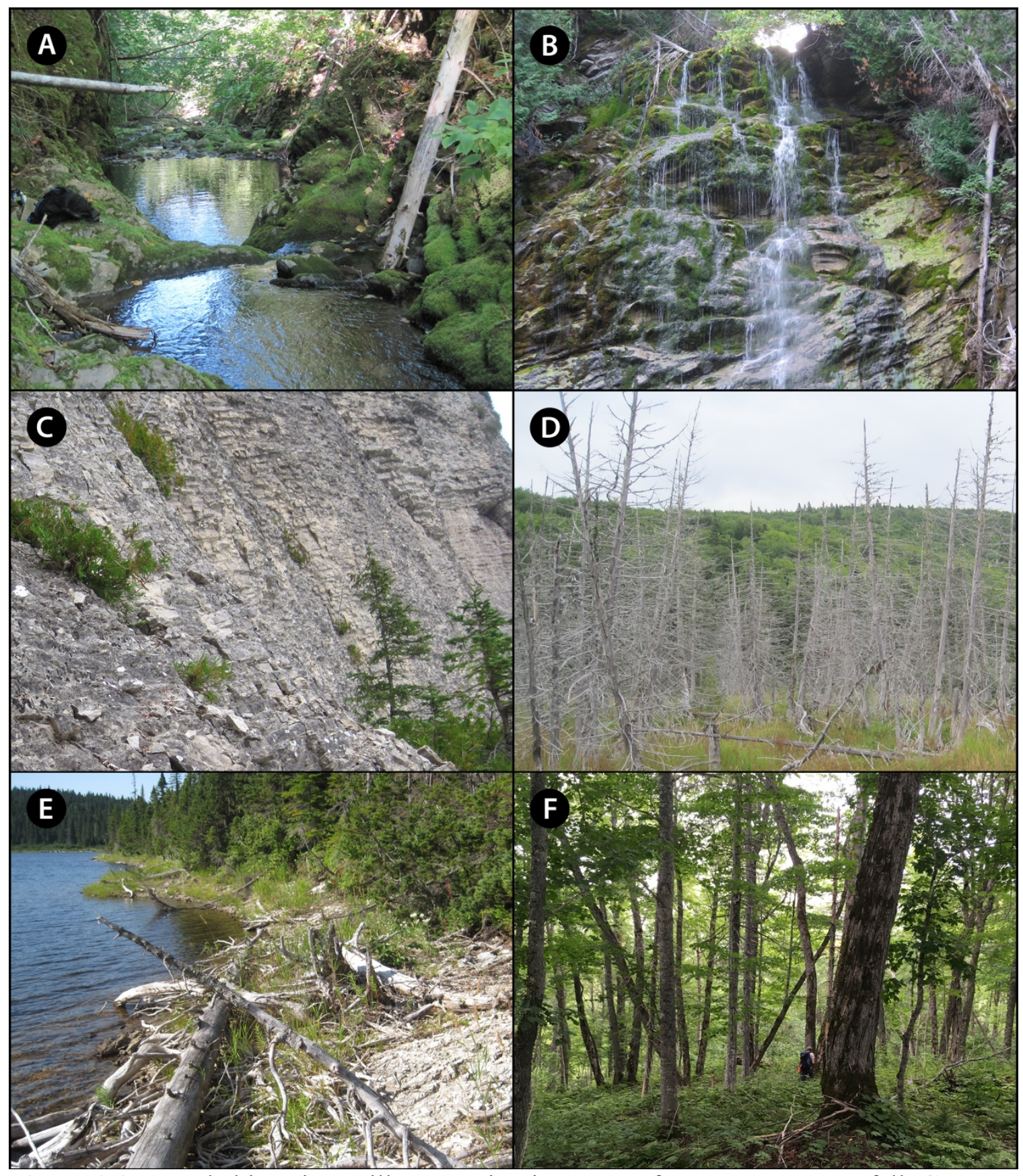

Figure 2.3. Mesohabitats in Forillon. A, Riparian areas of streams. B, Waterfall. C, Exposed calcareous cliffs. D, Thuja occidentalis swamp. E, Riparian areas of lakes. F, Old, Acer-dominated forest.

In addition to the collections made by H.P. in Forillon, we also examined herbarium specimens from the Academy of Natural Sciences of Drexel University (PH), Arizona State University Lichen Herbarium (ASU), CANL, Chrysler Herbarium at 
Rutgers University (CHRB), Field Museum of Natural History (F), Louis-Marie

Herbarium at Laval University (QFA), Michigan State University (MSC) and University of British Columbia Herbarium (UBC) for taxa recorded from Forillon that were not rediscovered during our fieldwork and some national and provincial collections of interest.

\subsubsection{Identification}

We examined external morphology using a Wild M5 stereo microscope and internal morphology, such as spore shape and size, using a Wild M20 compound microscope. To assess lichen chemistry, we used chemical spot tests: $10 \%$ and $20 \%$ potassium hydroxide $(\mathrm{KOH})$, calcium hypochlorite $(\mathrm{C})$, Lugol's iodine (I) and paraphenylenediamine (PD) in ethyl alcohol following Brodo et al. (2001). We also examined chemistry using an ultraviolet (UV) light chamber with longwave UV. For additional analysis of lichen products, we performed thin-layer chromatography (TLC) using glass plates coated with silica gel 60 F254 following Culberson and Kristinsson (1970) and Orange et al. (2010) in solvents A, B' and C. We used a Leica DVM6 digital microscope to photograph specimens (Fig. 2.4. A, E, Fig. 2.5. A, C, E, and Fig. 2.6. A). All identifications were made by H.P. and verified by the second author (R.T.M.) where necessary, except where stated otherwise in the annotated checklist. Specimens are housed at CANL in Gatineau, Quebec.

\subsubsection{Phytogeography and new records}

To verify that species are new reports for Forillon, Quebec or Canada we searched the databases of Canadensys, CANL, Consortium of North American Lichen Herbaria (CNALH), Global Biodiversity Information Facility (GBIF), and the New York Botanical 
Garden (NY). In addition, we conducted a review of salient North American lichen literature, including monographs (Ahti 1969; Ahti \& Brodo 1981; Brodo \& Hawksworth 1977; Degelius 1941; Dodge 1926; Esslinger 1977; Gowan \& Brodo 1988; Hinds et al. 1998; McMullin 2012, 2018; McMullin \& Dorin 2016; McMullin et al. 2017a, b; Otálora et al, 2014; Otte et al. 2005; Sierk 1964; Sirois et al. 1988; Stone et al. 2016, Velmala et al. 2014) and unpublished data on Quebec collections from R.T.M.

Using SimpleMappr (Shorthouse 2010), we prepared maps with data points gathered from CNALH, as well as published species occurrences not reflected in these databases (Ahti \& Brodo 1981, Brodo \& Hawksworth 1977, Laflamme-Levesque et al. 1979, Stone et al. 2016) to illustrate North American distributions (Fig. 2.4. B, D, F, Fig. 2.5. B, D, F and Fig. 2.6. B). We also checked the databases of Canadensys, CANL, GBIF, and NY but no additional occurrences were uncovered in these databases. We used QGIS to make the collection site map shown in Fig. 2.1 (QGIS Development Team 2019). For any taxon known from the park only by herbaria records, we obtained and verified voucher specimens.

\subsection{Results}

We discovered 123 taxa during our field surveys, which includes 122 species and two subspecies in 39 genera. Thirteen genera, 59 species and one subspecies are new to the park. We also verified lichen collections in herbaria made by other researchers over the past 49 years, which represent an additional 17 taxa that we did not rediscover during our study (total macrolichens in the park $=139$ species and two subspecies). We report one species, Melanohalea exasperata, for the first time in Canada; one species, Scytinium 
teretiusculum, for the first time in Quebec; three species, Bryoria salazinica, Cladonia labradorica, and Leptogium acadiense, are endemic to northeastern North America; one species, Parmelia fertilis, has a notable northerly range extension; and one species, Hypogymnia subobscura, has a distinct Arctic affinity and is atypical of this low latitude and elevation. Seven species: Bryoria pikei, Collema nigrescens, C. subflaccidum, Hypogymnia tubulosa, Lobaria pulmonaria, L. quercizans and Usnea longissima, are considered indicators of old growth forests by Selva (1994). The taxa reported herein represent fruticose (58 taxa, $41.4 \%$ ), foliose (76 taxa, 54.3\%) and squamulose (6 taxa, 4.3\%) growth forms. Cyanobacteria are the photobiont in 29 taxa $(20.7 \%)$, algae are the photobiont for 104 taxa (74.3\%), and seven species (5\%) contain both (algae are the primary photobiont and cyanobacteria are in cephalodia). Reproductive strategies observed were vegetative through propagules (i.e., soredia or isidia) (40\%), sexual through ascospores (35\%), and both vegetative and sexual (12.9\%). An annotated checklist of species and identification key to the macrolichens of Forillon is provided in Appendix A.2 and A.3, respectively.

\subsection{Discussion}

Forillon contains an interesting macrolichen biota. Notable discoveries include: Bryoria salazinica, Cladonia labradorica, Hypogymnia subobscura, Leptogium acadiense, Melanohalea exasperata, Parmelia fertilis and Scytinium teretiusculum. Bryoria salazinica was reported from Maine, Massachusetts, New Brunswick, Newfoundland, Nova Scotia, and Prince Edward Island by Brodo and Hawksworth (1977). This species has been reported once before from Quebec, on Anticosti Island 
(Laflamme-Levesque et al. 1979), our collection represents the second record for Quebec, ninth record for Canada, and eleventh record globally. This species appears to be endemic to northeastern North America, where it is rare in hyper-coastal environments (Fig. 2.4. A-B). Cladonia labradorica, described by Ahti and Brodo (1981), was known only from the northern boreal forests of the Ungava-Labrador Peninsula. Since 1981, additional collections have been reported from Nova Scotia and New Hampshire (Hinds \& Hinds 2007), but it appears to be rare (Ahti \& Brodo 1981, Hinds \& Hinds 2007) and endemic to northeastern North America (Ahti pers. comm.) (Fig. 2.4. C-D). Hypogymnia subobscura, a typically Arctic/alpine species, is uncommon at lower latitudes (with the exception of a few disjunct records in the Rocky Mountains in Washington, Montana and Colorado) (CNALH 2019). In eastern North America, south of the $60^{\text {th }}$ parallel north, it is only known from the province of Quebec (CNALH 2019), our collection is the second published report and sixth record of this species in eastern North America south of the $60^{\text {th }}$ parallel north (Fig. 2.4. E-F). Leptogium acadiense was recently described by Stone et al. (2016) from Nova Scotian collections. It is also known from Newfoundland, Ontario, Quebec, Maine, Massachusetts, Michigan, Minnesota, New Hampshire, North Carolina, Vermont, and a few disjuncts in the Great Smoky Mountains (CNALH 2019, Stone et al. 2016) and seems to be endemic to eastern North America (Stone et al. 2016) (Fig. 2.5. A-B). Melanohalea exasperata had no published reports in Canada and few collections, which all appeared to be historical (CNALH 2019). Therefore, we reviewed all available Canadian collections of M. exasperata and discovered that previous collections from Quebec are misidentifications, thus we report this species for the first time from the province. In Canada, this species is rare, we were only able to confirm a 
single record from New Brunswick. All other examined material were misidentifications, making our collection in Forillon also the first confirmed published report and the second collection in Canada (Fig, 2.5. C-D). There are four additional Canadian collections from Alberta (2), New Brunswick (1) and Ontario (1) that were not available to us to verify, these collections are unpublished and have incomplete location data and have thus not been included here. Parmelia fertilis, although it appears to be fairly widespread in the States (based on CNALH collections), is noted by Hinds \& Hinds (2007) to be rare and only historically widespread in the States. The first published report of this species in North America was by Hale (1987) based on specimens from New Brunswick and Nova Scotia (Gowan \& Brodo 1988), since then it has been reported from New Hampshire (Cleavitt et al. 2019), Maine and southern Quebec (Hinds et al. 1998). Our collection is the most northerly occurrence of this species in North America (Fig. 2.5. E-F). Scytinium teretiusculum is known from five provinces in Canada: Alberta, British Columbia, New Brunswick, Nova Scotia, and Ontario (Sierk 1964). There are two unpublished collections listed on CNALH from Quebec, thus ours is the first published occurrence and third collection of this species in the province (Fig. 2.6. A-B). 


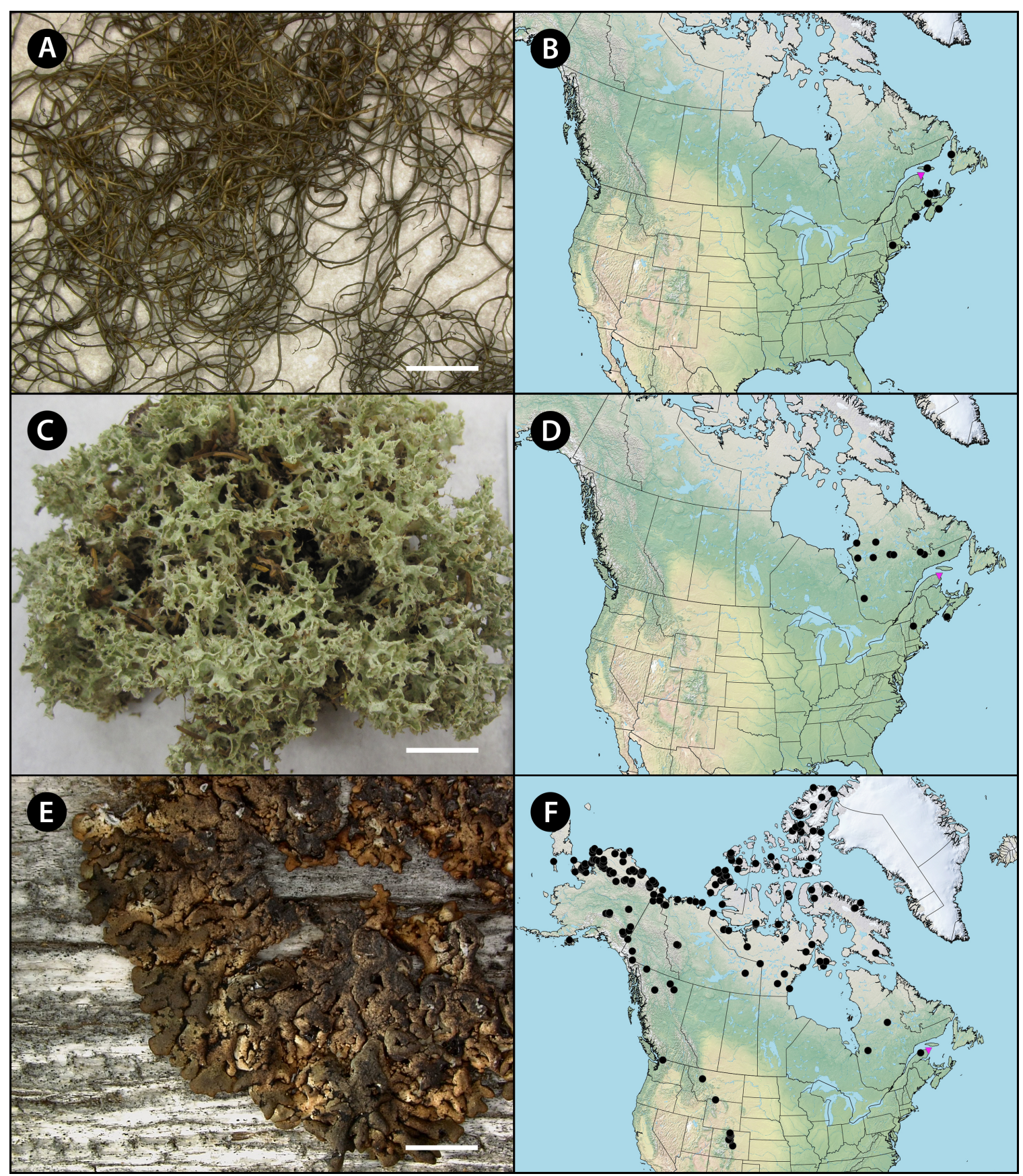

Figure 2.4. Species of interest in Forillon and their North American geographic

distributions. A-B, Bryoria salazinica (A from H.A. Paquette 59, CANL). C-D, Cladonia labradorica (C from H.A. Paquette 685, CANL). E-F, Hypogymnia subobscura (E from H.A. Paquette 1007, CANL). Known North American geographic distributions shown in black, Forillon collections shown in pink. Scales: $8 \mathrm{~mm}$. in A, $10 \mathrm{~mm}$. in C, $30 \mathrm{~mm}$. in E. 


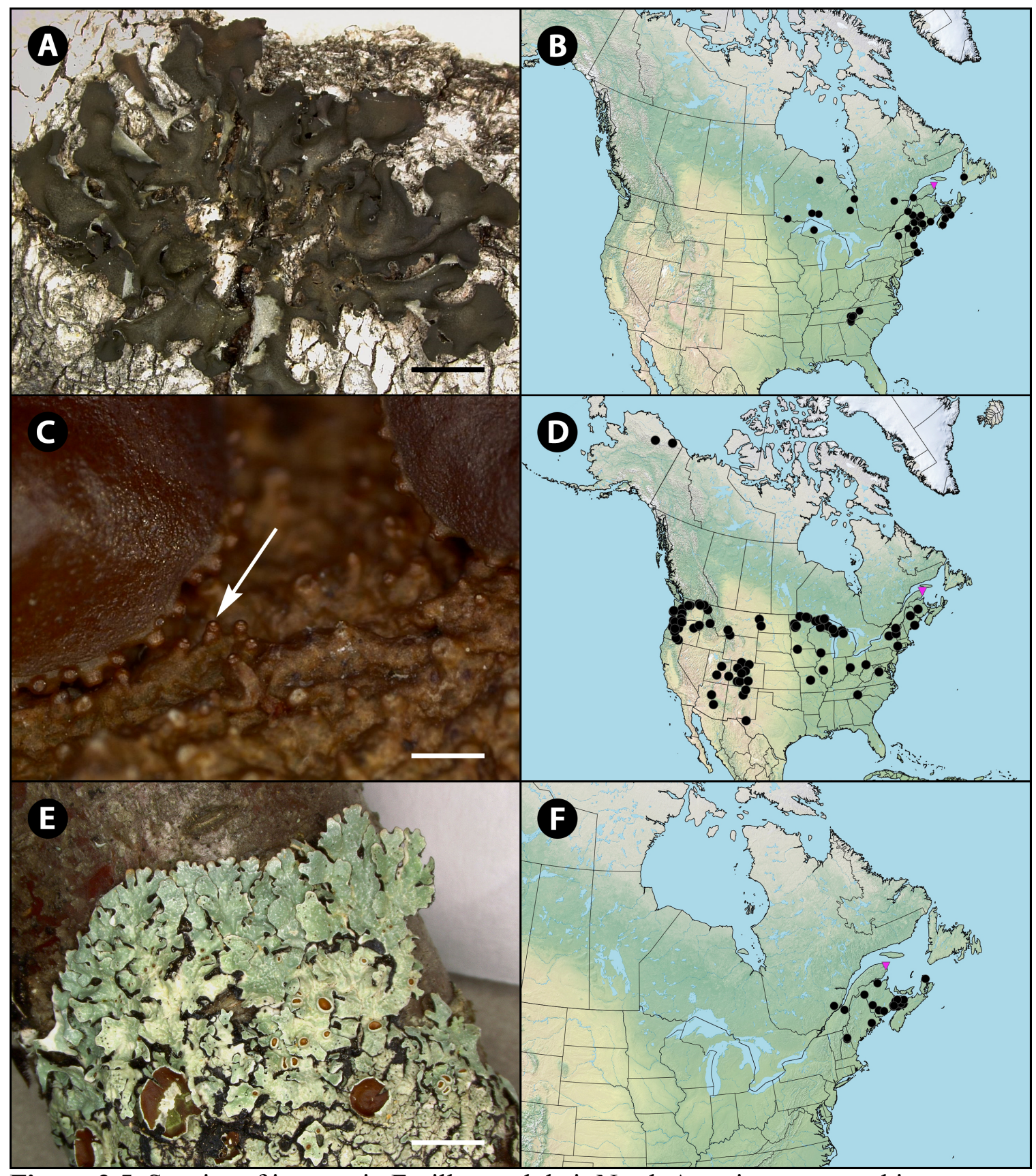

Figure 2.5. Species of interest in Forillon and their North American geographic distributions, continued. A-B, Leptogium acadiense (G from H.A. Paquette 375, CANL). C-D, Melanohalea exasperata (I from H.A. Paquette 797, CANL). E-F, Parmelia fertilis (K from H.A. Paquette 470, CANL). Known North American geographic distributions shown in black, Forillon collections shown in pink. Scales: $20 \mathrm{~mm}$. in A, $0.5 \mathrm{~mm}$. in C, $10 \mathrm{~mm}$. in E. 


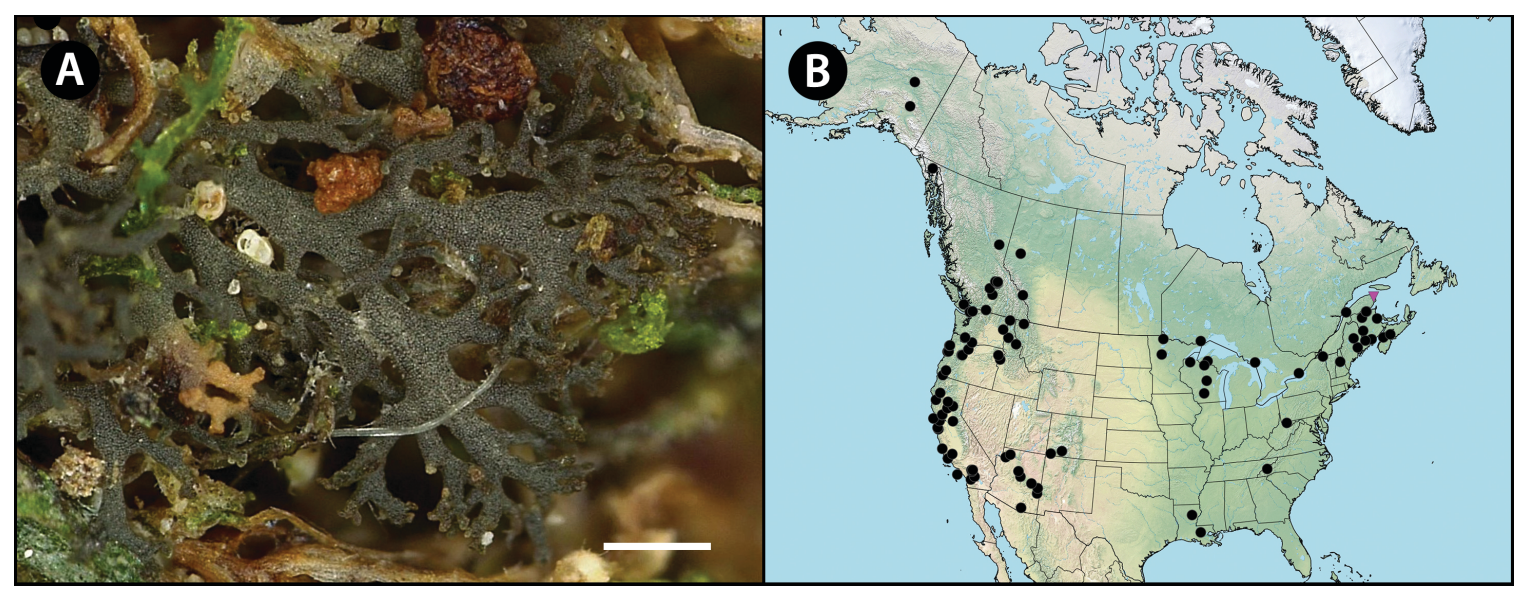

Figure 2.6. Species of interest in Forillon and their North American geographic distributions, continued. A-B, Scytinium teretiusculum (M from H.A. Paquette 791B, CANL). Known North American geographic distributions shown in black, Forillon collections shown in pink. Scales: $0.2 \mathrm{~mm}$ in A.

Species with an algal photobiont are the most abundant in the park. However, we also discovered 29 cyanolichens in 12 genera (Table 2.1). Cyanolichens require higher moisture levels to photosynthesize than lichens with algal photobionts (Cameron \& Richardson 2006, Goward \& Arsenault 2000). The cyanolichens we found were typically in habitats and microhabitats where relative humidity was higher than the surrounding environments, such as tree bases, coastal forests, and the banks of shaded streams and waterfalls. Cyanolichens are important functional components of ecosystems, as they fix atmospheric nitrogen (Pike 1978). Worldwide, ca. 10\% of lichen species are cyanolichens (Cameron \& Richardson 2006). This group is especially sensitive to air pollution (Richardson 1992) and, as a result, are useful indicators of environmental degradation, particularly arboreal species (Goward \& Arsenault 2000). Concerns for the welfare of cyanolichens nationally and abroad are well documented (Anderson 2007, Cameron \& Richardson 2006, Merinero et al. 2014). Our results from Forillon establish a baseline from which presence/absence of these sensitive species can be monitored. 
Table 2.1. Cyanolichens reported in Forillon. Reports based on herbarium vouchers verified by the authors are followed by an asterisk $(*)$.
Collema furfuraceum
C. nigrescens
C. subflaccidum
Lathagrium fuscovirens*
L. undulatum
Leptogium acadiense
L. cyanescens
Lobaria scrobiculata
Nephroma bellum
N. laevigatum
N. parile
Pannaria rubiginosa
Parmeliella triptophylla
Peltigera elizabethae
$P$. canina*
P. degenii*
$P$. extenuata
P. horizontalis
P. malacea
P. membranacea
P. neopolydactyla
$P$. praetextata
$P$. rufescens
Placynthium nigrum
Protopannaria pezizoides
Scytinium lichenoides
S. tenuissimum
S. teretiusculum
Vahliella leucophaea

Seven of the species that we located are "faithful" to ancient forests in the Acadian forest region (Selva 1994): Bryoria pikei, Collema nigrescens, C. subflaccidum, Hypogymnia tubulosa, Lobaria pulmonaria, L. quercizans, and Usnea longissima. Rose (1974, 1976) first used lichens as indicators of old-growth or ancient forests in lowland deciduous stands in Great Britain and France. He developed an index of ecological continuity (IEC) to classify and measure these forests. Hawksworth \& Hill (1984) expected that Rose's method could be applied beyond Great Britain and for other forest 
types. Selva $(1994,1999)$ then developed an IEC in North America by adapting Rose's list of indicator species to establish two suites of lichens (one each for deciduous- and conifer-dominated forests) to assess temporal continuity of stands in the Acadian forest. Both Rose $(1974,1976)$ and Selva $(1994,1999)$ selected a variety of indicator species, including crustose and calicioid lichens in addition to the macrolichens. Unfortunately, our study did not target specific stands, so collecting was too dispersed for pre-existing IECs to be applied. However, if an IEC were to be used, an appropriate suite of species should be selected, including macrolichen and microlichen (e.g., crustose and calicioid species) species, since Forillon is mostly boreal forest.

Forillon is part of the northernmost portion of the Appalachian Mountains in continental North America. In the southern Appalachians, more research has been done and the region is a well-known hotspot for lichen diversity and endemism (Allen et al. 2018, Degelius 1941, Lendemer et al. 2013, Selva 2016, Tripp et al. 2016). Additionally, the southern Appalachians are recognized as a highly endangered ecosystem (Allen \& Lendemer 2016b, White et al. 2012). In contrast, much less is known about the lichen biota of the northern Appalachians, except for a few contemporary studies (e.g., McMullin \& Dorin 2016, McMullin et al. 2017b, Sirois et al. 1988) and fewer historical accounts (e.g., Dodge 1926). In the southern Appalachians, Allen \& Lendemer (2016b) used species distribution modelling to forecast the impacts of climate change on eight high-elevation endemic lichen species. Their results suggest significant habitat loss will occur due to climate change. A notable requirement for Allen \& Lendemer's (2016b) study was "robust published evidence from large scale biodiversity inventories, floristic treatments and taxonomic revisions that the species were endemic to the study area" (p. 
557). To properly evaluate the degree of threat and appropriate conservation actions of any species or ecosystem, comprehensive baseline is required (Allen \& Lendemer 2016b, Balmford et al. 2005, Environment Canada 1995, Giangrande 2003, Merinero et al. 2014, Monastersky 2014, Pimm et al. 1995, Powell et al. 1999, Scheidegger \& Werth 2009).

Our results contribute to establishing a better understanding of the lichen biota in the northern Appalachian Mountains and the Gaspé Peninsula (e.g., Dodge 1926, McMullin \& Dorin 2016, McMullin et al. 2017b, Sirois et al. 1988). They also add to notable work on lichen biogeography and diversity in eastern Canada (e.g., Gowan \& Brodo 1988; McMullin 2009, 2012, 2015; McMullin \& Wiersma 2017; McMullin et al. 2008, 2017a; Selva 1999), and more broadly to the body of knowledge on Appalachian lichens (e.g., Allen \& Lendemer 2016b; Selva 2013, 2014, 2016; Lendemer et al. 2013).

Notwithstanding a few well studied areas, there remain significant knowledge gaps in Canada's lichen biota despite their importance to conservation monitoring and management (Allen \& Lendemer 2016a, $b$; Henderson 2000; McMullin \& Wiersma 2019; McMullin et al. 2008; Richardson 1992; Rose 1974, 1976; Selva 1999, 2003; Tibell 1992). We have filled a small gap at Forillon, but lichens warrant continued study throughout Canada, particularly for monitoring the effects of a changing climate. 


\section{Chapter 3: The calicioids of Forillon National Park, Quebec, Canada}

I spy with my little eye, lichens all but a millimeter high.

They inhabit small spaces, and in many cases;

regarding forest continuity, they don't lie.

\subsection{Abstract}

The distribution of calicioid lichens and fungi is poorly understood in many areas of North America. For example, there were no previously known collections from Forillon National Park in Quebec, Canada. Therefore, we conducted a comprehensive inventory of the calicioid species in this unexplored area and discovered 30 species in nine genera. One species, Chaenothecopsis oregana, is new to eastern North America; two species, Calicium denigratum and Sclerophora coniophaea, are new to Quebec; and one species, Sclerophora peronella, is listed under Schedule 1 of the Canadian Species at Risk Act. We present an annotated checklist and a key to the calicioid species of Forillon National Park.

\subsection{Keywords}

Appalachians, Caliciales, Coniocybaceae, biogeography, Gaspé Peninsula, Mycocaliciaceae, Physciaceae, Sphinctrinaceae.

\subsection{Introduction}

The calicioid lichens are lichenized fungi with ephemeral asci that break down before the ascospores have matured to form a mazaedium (Tibell 1996, 1999). This group of lichens is often referred to as 'pin' or 'stubble' lichens due to their minute, typically hair-like fruiting bodies (Selva 2003). Non-lichenized fungi that share this distinctive 
form are traditionally treated with their lichenized counterparts, despite lacking a mazaedium, and are collectively known as 'calicioid fungi' (Tibell 1996, 1999). Calicioids, whether lichens or non-lichen fungi, colonize a variety of substrates, most commonly the wood and bark of conifers and angiosperms (Selva 2003). Furthermore, many species are host specific and only grow on one genus or species of tree, or other lichen (Selva 2014, Tibell 1999). Many calicioids also require specialized habitats such as old-growth forests (McMullin et al. 2008, Selva 2003, Tibell 1992). Perhaps due to their tiny stature and highly specialized microhabitat requirements, calicioids are poorly understood in many areas of North America. For example, no calicioids have previously been reported from Forillon National Park (hereafter Forillon).

Forillon is located at the northernmost tip of the Gaspé Peninsula of eastern Quebec, Canada. It is in the boreal forest and the continental terminus of the Appalachian Mountain range (Government of Canada 2010, St-Amour 1985). Although portions of the lichen biota of the southern Appalachian Mountains have been well surveyed (e.g., Allen \& Lendemer 2016b, Lendemer et al. 2013), limited data are available in the central and northern parts of the mountain range. Before initiating our investigation, we hypothesized that Forillon would contain a rich calicioid biota because of its old-growth forests, treed wetlands, and mix of conifer and angiosperm tree species (Government of Canada 2017, St-Amour 1985), and because the nearby parc national de la Gaspésie (hereafter PNG) contains 53 species of calicioids (McMullin unpublished data). Although Forillon is neither as large as PNG, nor has as diverse a landscape, we still expected it to contain many calicioid species.

The aim of our study was to complete a comprehensive survey of Forillon for 
calicioids. Our objectives were to examine all major ecosystems in the park, explore as many meso- and microhabitats as possible, provide a dichotomous key to the species discovered, and highlight any species of interest. The results presented here expand the biogeographic understanding of calicioids in Canada and North America, establish a baseline from which future monitoring can be conducted, and provide a tool to recognize and study this group in the park.

\subsection{Methods}

\subsubsection{Study area}

Forillon National Park is located in the province of Quebec, Canada (Fig. 3.1). It is on the Gaspé Peninsula, bordered by the Gulf of St. Lawrence along its north shore and the Bay of Gaspé on its south shore. It is part of the northern extension of the Acadian Forest Ecoregion, also known as the Northern Appalachian Ecoregion (Selva 2013, Trombulak et al. 2008). The Canadian segment of this ecoregion is called the Atlantic Maritime Ecozone (Ecosystem Stratification Working Group 1995). Forillon protects $244.8 \mathrm{~km} 2$ of terrestrial and marine habitat (Government of Canada 2017, St-Amour 1985). Boreal forests are dominant at higher elevations (the highest elevation that we recorded was 494 metres) and on the Penouille sandspit, while there is a mix of hardwood and softwood species, typical of the Acadian forest, in the Anse-au-Griffon valley and lower lying areas such as La Chute Trail. Due to the unique geography and geology of this region, Forillon contains a high diversity of habitats despite its relatively small size. These include: taiga (i.e., barren boreal forest), alpine meadow, marine-intertidal zone, freshwater lakes and streams, and exposed calcareous cliffs (Government of Canada 
2010, 2017; St-Amour 1985). The taiga habitat on the Penouille sandspit, which stretches into the Bay of Gaspé in the south sector of the park, is of particular note as this biome is not typical of such a low latitude (Government of Canada 2017, St-Amour 1985). The mean temperature, based on data from the nearest weather station (Cap Des Rosier) from $1981-2010$, is $-9.8^{\circ} \mathrm{C}$ in January and $16.2^{\circ} \mathrm{C}$ in July and the average annual precipitation is $1195.1 \mathrm{~mm}$, with approximately $74 \%$ as rain and $26 \%$ as snow (Environment Canada 2019).

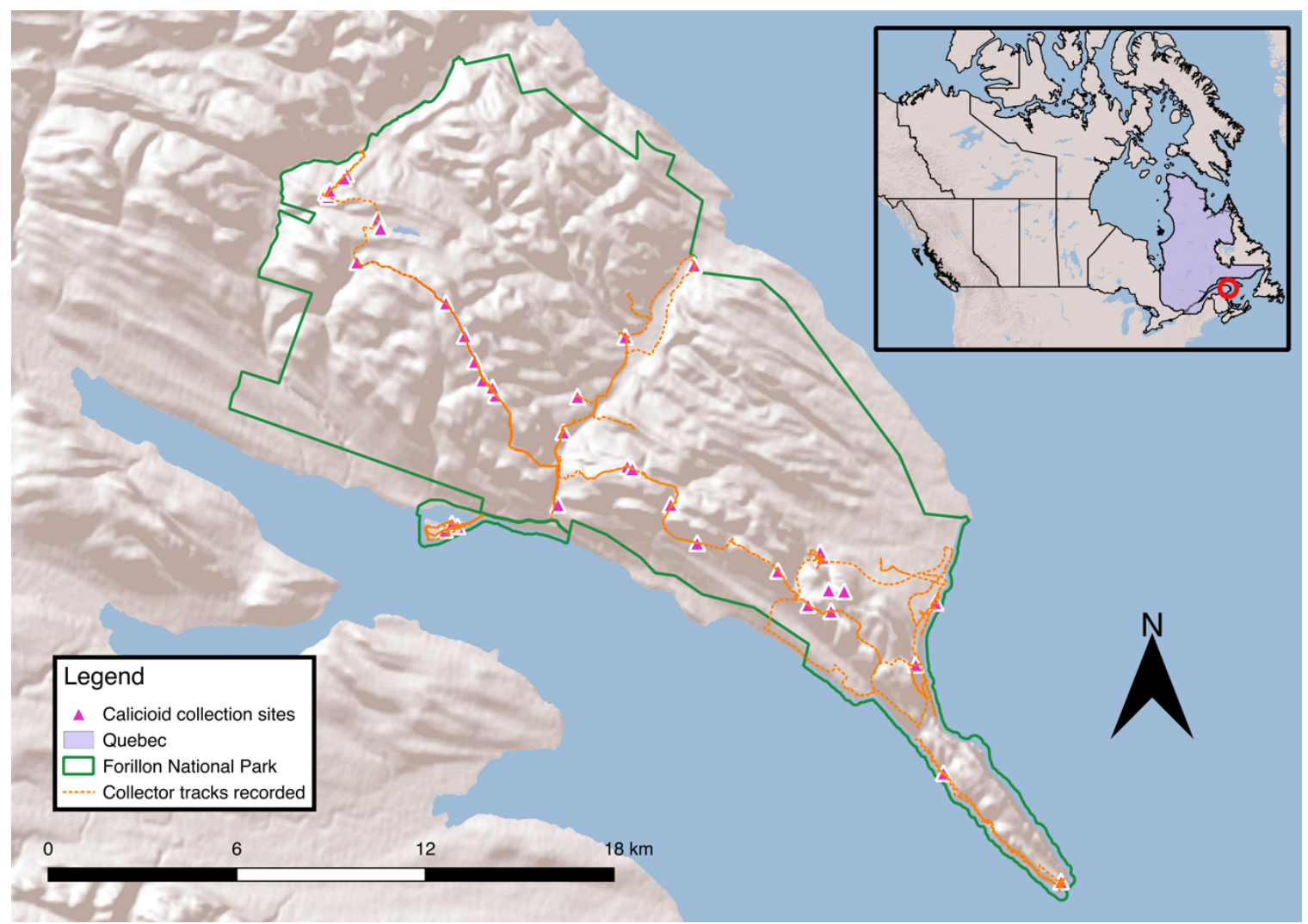

Figure 3.1. Location of the collection sites in Forillon National Park, and of the study area in Quebec, Canada. Map is presented in NAD83.

Prior to its designation as a national park in 1970, Forillon had a rich cultural history. Indigenous people used the Anse-au-Griffon valley to portage across the peninsula between the Gulf of St. Lawrence and the Bay of Gaspé (Government of Canada 2010, 2017; St-Amour 1985). There is also evidence of extensive tool-making 
and domestic activity on the Penouille sandspit (Government of Canada 2017, St-Amour 1985). European exploitation of Forillon's productive shoreline waters began in the 1500 s and permanent settlement of the region was established at the end of the $1700 \mathrm{~s}$ with the arrival of English fishing companies (Government of Canada 2017, St-Amour 1985). Agriculture and logging were not established until the mid-1800s, and then only in the Anse-au-Griffon valley due to the rugged topography of the peninsula (Government of Canada 2017, St-Amour 1985). This was, however, successful enough to attract timber export companies in the 1900s (Government of Canada 2017, St-Amour 1985). Human activities during the 1900s, including logging and the establishment of farming communities, transformed the forests of Forillon (Government of Canada 2017, StAmour 1985). Today, the park maintains approximately 146 kilometres of hiking and multi-use trails, 352 semi-serviced campsites, and 16 diversified accommodations (e.g., four-season tents) (Government of Canada 2017). In 2017, Forillon had 45,018 visitors (Government of Canada 2018). Contemporary disturbances of note that influence the ecology of Forillon include: prescribed burning conducted by park management to reestablish white pine and red oak; the re-routing of QC-132 (a provincial highway in Quebec) in the north sector which was completed in 2018 (Government of Canada 2018); and browsing by moose, which are overabundant in the park (Sigouin et al. 2013).

\subsubsection{Sampling}

All major ecosystems and as many meso- and microhabitats as possible were surveyed in Forillon by the first two authors (H.P. and N.v.M) between August 20 and September 23, 2018. We followed the Floristic Habitat Sampling method described by Newmaster et al. (2005). Those authors showed that habitat sampling more widely 
captures greater cryptogam diversity than representative plot sampling methods. Selva $(1999,2003,2016)$ also used this method for the discovery of calicioid species. We specifically sought microhabitats known to host calicioid species (Fig. 3.2), including decorticate stumps and snags, large hollows in standing trees, hardened resin of coniferous trees, forests and tree stands with humid microclimates and the bark and twigs of as many different types of tree species as possible (Selva 2014, 2016; Tibell 1999). 


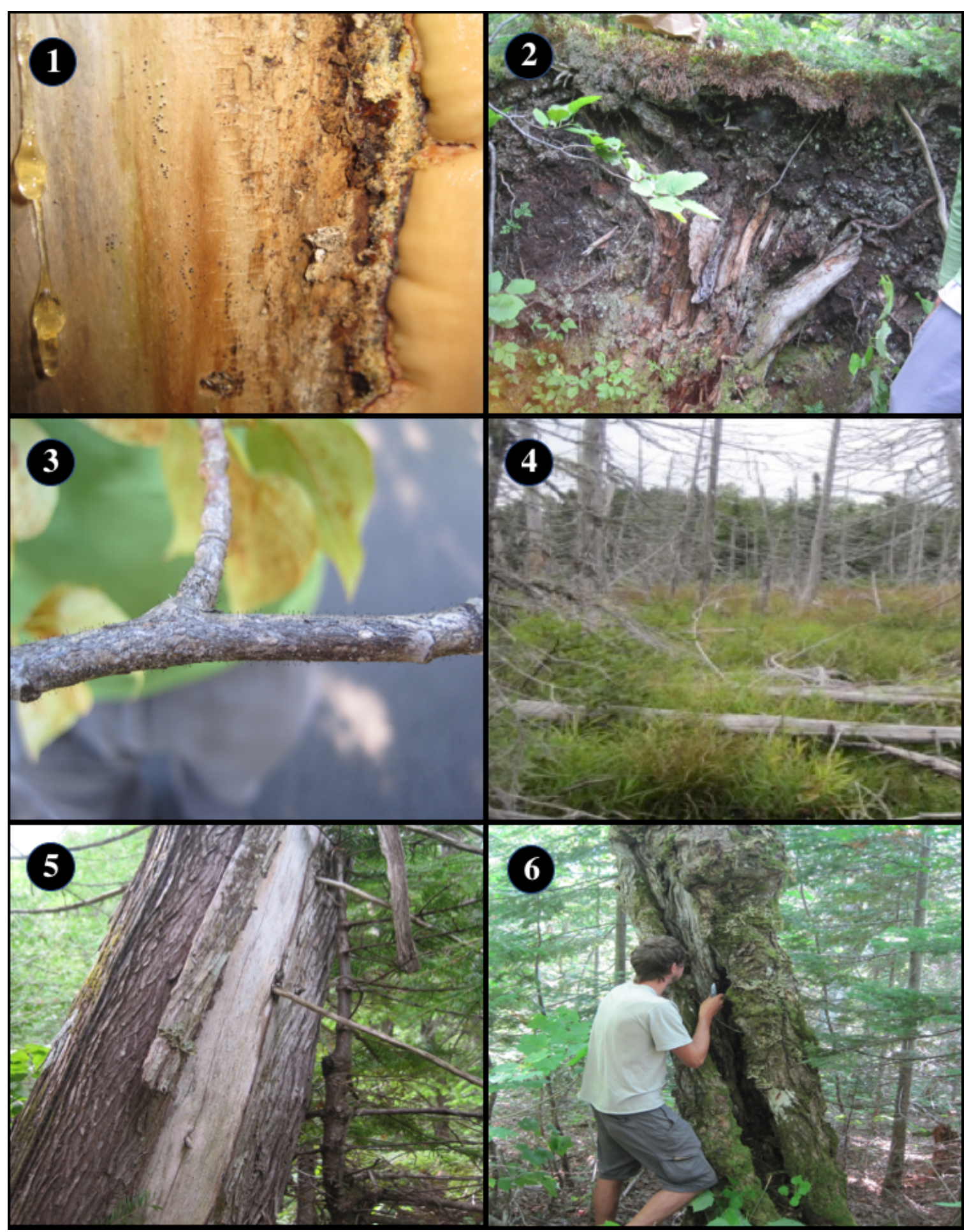

Figure 3.2. Microhabitats of interest for calicioids in Forillon National Park. A, Hardened resin on exposed wood of conifers. B, Roots and soil of upturned trees. C, Smooth bark of the twigs and branches of young deciduous trees. D, Exposed Thuja occidentalis swamp. E, Wet Thuja occidentalis forest, dominated by mature, large Thuja occidentalis. F, exposed heartwood of Acer, in protected hollow. 


\subsubsection{Identification}

We used a Wild M5 stereo microscope to examine external morphology, a Wild M20 compound microscope to examine internal morphology and chemical reactions with $20 \%$ potassium hydroxide $(\mathrm{KOH})$, Lugol's iodine $(\mathrm{I})$, paraphenylenediamine $(\mathrm{PD})$ and 50\% nitric acid (N) following Brodo et al. (2001). We used a Leica DVM6 digital microscope to photograph apothecia (Figs. 3.3A, 3.4A, 3.5A, 3.6A) and a Leica DMR compound microscope with PixelLINK digital camera to photograph specimen ascospores in wet mounts (Figs. 3.3B, 3.4B, 3.5B, 3.6B). For imaging ascospore ornamentation, we used a FEI Apreo scanning electron microscope (SEM). We mounted apothecia on aluminium stubs with double-sided carbon tape, then used a Denton Desk II Sputter Coater to coat specimens with gold/palladium. SEM photographs were taken under high vacuum using the $\mathrm{T} 1$ detector (Figs. 3.3C, 3.4C, 3.5C, 3.6C). Using SimpleMappr (Shorthouse 2010), we prepared maps with data points gathered from herbaria databases (CNALH 2019, GBIF 2019), as well as published species occurrences not reflected in these databases (COSEWIC 2014; Haughland \& Martel 2016; McMullin et al. 2012; Selva 2013, 2014) and unpublished data from the fourth author (R.T.M.) for calicioids in PNG (Quebec) and Kejimkujik National Park (Nova Scotia) to illustrate North American species distributions (Figs. 3.3D, 3.4D, 3.5D, 3.6D). Additional data points were searched for on the Canadian Museum of Nature and the New York Botanical Garden databases, but we found no additional collections. We used QGIS to create the site map shown in Fig. 3.1 (QGIS Development Team 2019). The specimens for this study are housed at the Canadian Museum of Nature (CANL) in Gatineau, Quebec. 


\subsubsection{New records}

To verify that species are newly reported from the park and Quebec, we performed database searches of Canadensys, Canadian Museum of Nature, Consortium of North American Lichen Herbaria, Global Biodiversity Information Facility, and New York Botanical Garden. In addition, we a conducted a review of salient North American calicioid literature (Haughland \& Martel 2016; McMullin 2018; McMullin et al. 2012; McMullin et al. 2018; Selva 2010, 2013, 2014; Selva \& Tibell 1999; Tuovila et al. 2011; Tuovila et al. 2012) and unpublished data from R.T.M. for calicioids in PNG.

\subsection{Results}

We discovered 30 species in nine genera during our survey. Sixteen species are calicioid lichens (lichenized) and 14 are calicioid fungi (non-lichenized). Based on our investigation of herbaria records and a literature review, no calicioid lichens or fungi have been reported from Forillon prior to our study, so all the species are new to the park. One species, Chaenothecopsis oregana (Fig. 3.3A-D), is new to eastern North America. Two species, Calicium denigratum (Fig. 3.4A-D) and Sclerophora coniophaea (Fig. 3.5A-D), are new to Quebec. Finally, one additional species, Sclerophora peronella (Fig. 3.6A-D), is listed under Schedule 1 of the Canadian Species at Risk Act (Government of Canada 2019). An annotated checklist of calicioid species and identification key to the calicioid species of Forillon is provided in Appendix B.2 and B.3, respectively. 


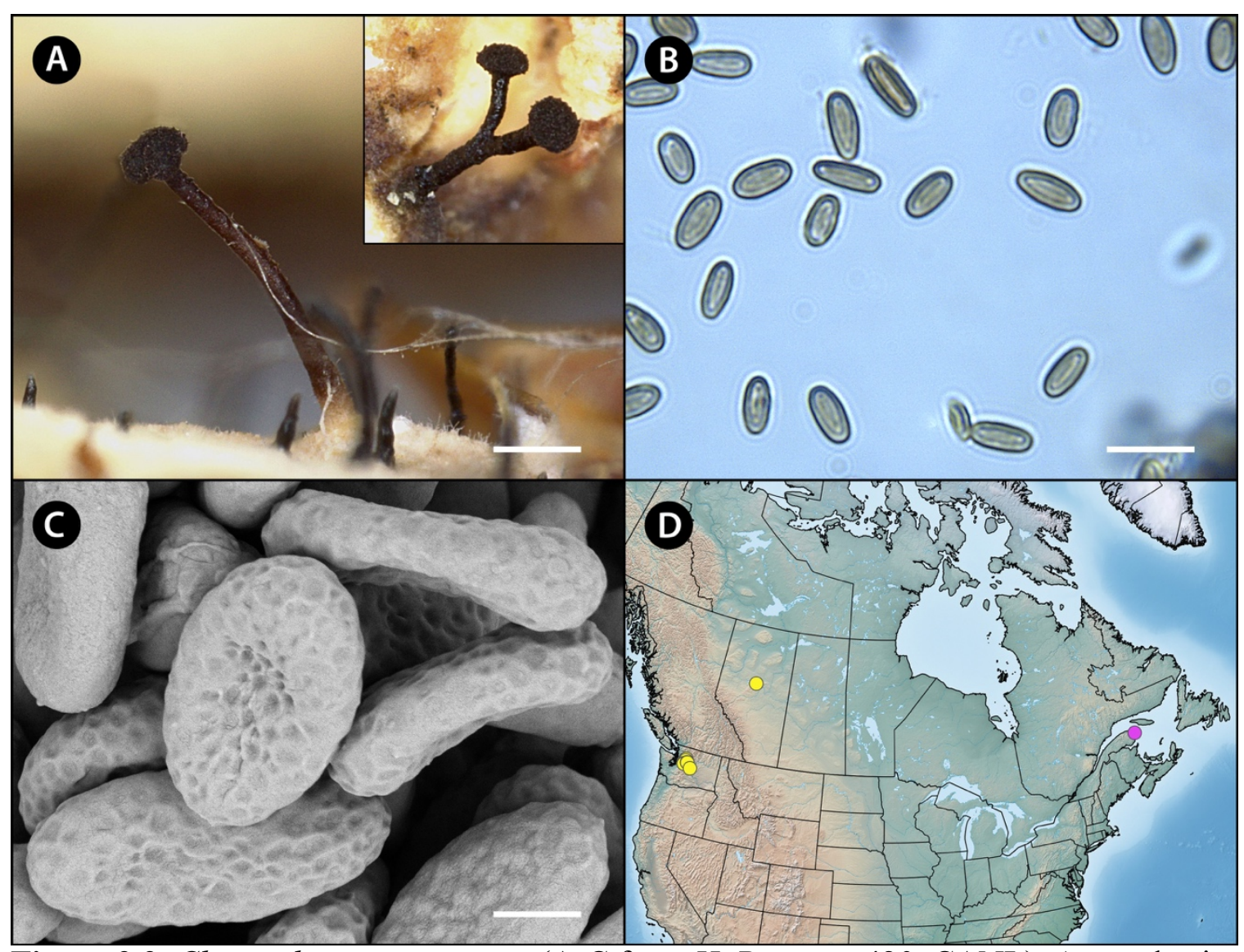

Figure 3.3. Chaenothecopsis oregana (A-C from H. Paquette 420, CANL). A, apothecia (inset depicts typical forked stalks). B, ascospores viewed under compound microscope. C, ascospores viewed under a scanning electron microscope. D, known North America geographic distribution (pink $=$ Forillon occurrence, yellow $=$ other occurrences). Scales $=0.15 \mathrm{~mm}$ in $\mathrm{A}, 9 \mu \mathrm{m}$ in $\mathrm{B}, 1.75 \mu \mathrm{m}$ in $\mathrm{C}$. 


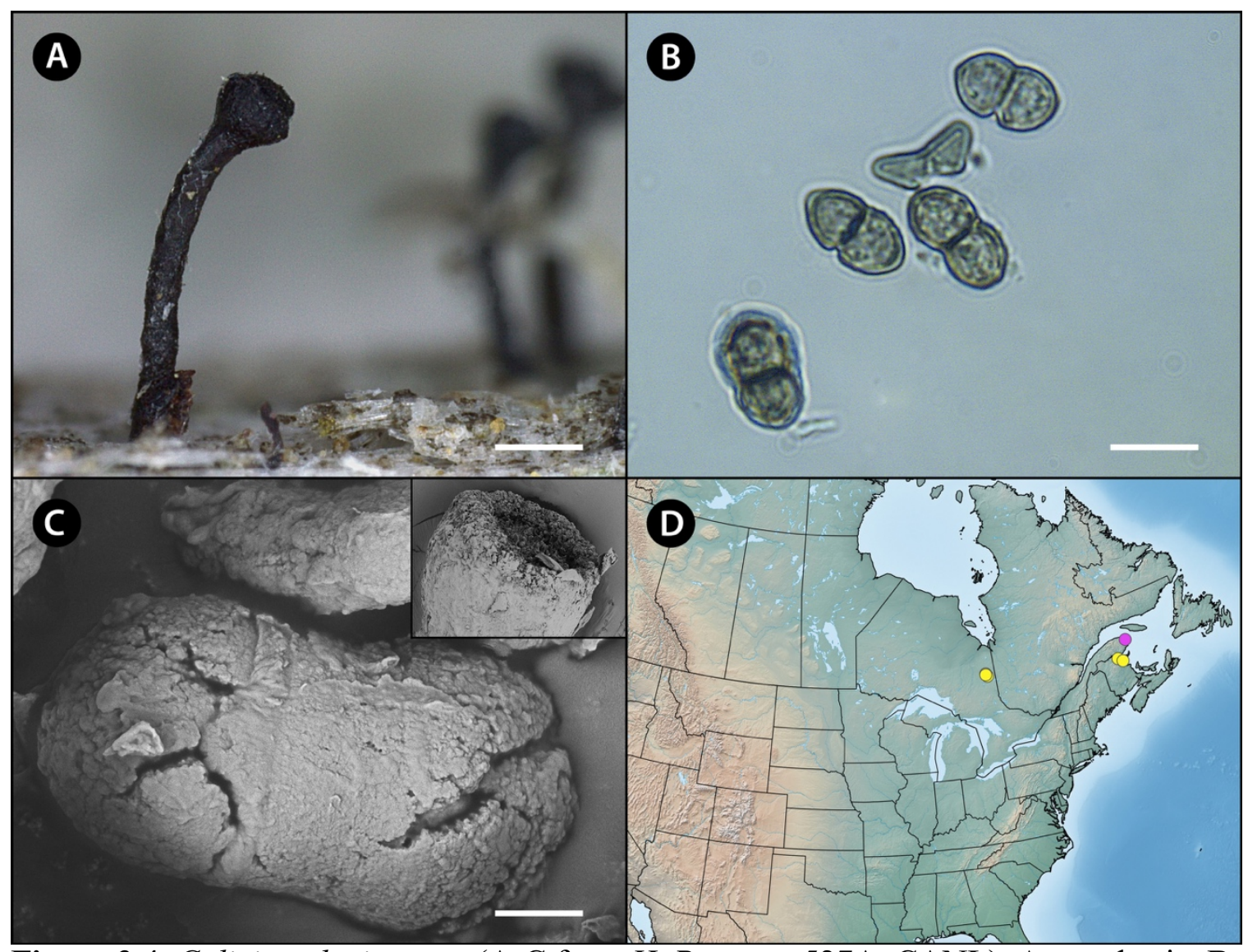

Figure 3.4. Calicium denigratum (A-C from H. Paquette 527A, CANL). A, apothecia. B, ascospores viewed under compound microscope. $\mathbf{C}$, ascospores under a scanning electron microscope (inset illustrates characteristic bell-shaped capitulum). D, known North America geographic distribution $($ pink $=$ Forillon occurrence, yellow $=$ other occurrences). Scales $=0.35 \mathrm{~mm}$ in $\mathrm{A}, 9 \mu \mathrm{m}$ in $\mathrm{B}, 1.75 \mu \mathrm{m}$ in $\mathrm{C}$. 


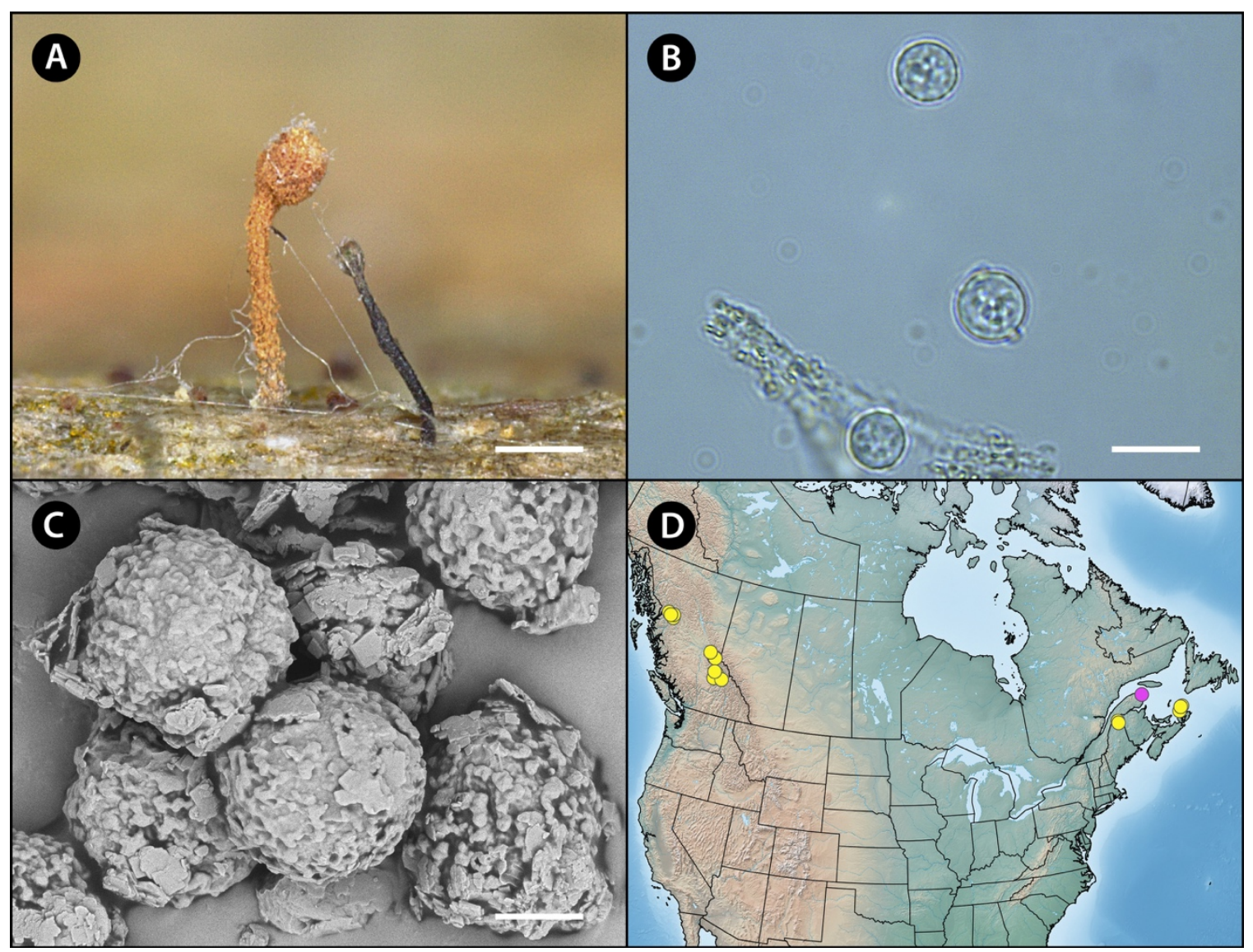

Figure 3.5. Sclerophora coniophaea (A-C from H. Paquette 447, CANL). A, apothecia. $\mathbf{B}$, ascospores viewed under compound microscope. $\mathbf{C}$, ascospores viewed under a scanning electron microscope. D, known North America geographic distribution (pink = Forillon occurrence, yellow $=$ other occurrences). Scales $=0.30 \mathrm{~mm}$ in A, $6 \mu \mathrm{m}$ in B, 2.6 $\mu \mathrm{m}$ in $\mathrm{C}$. 


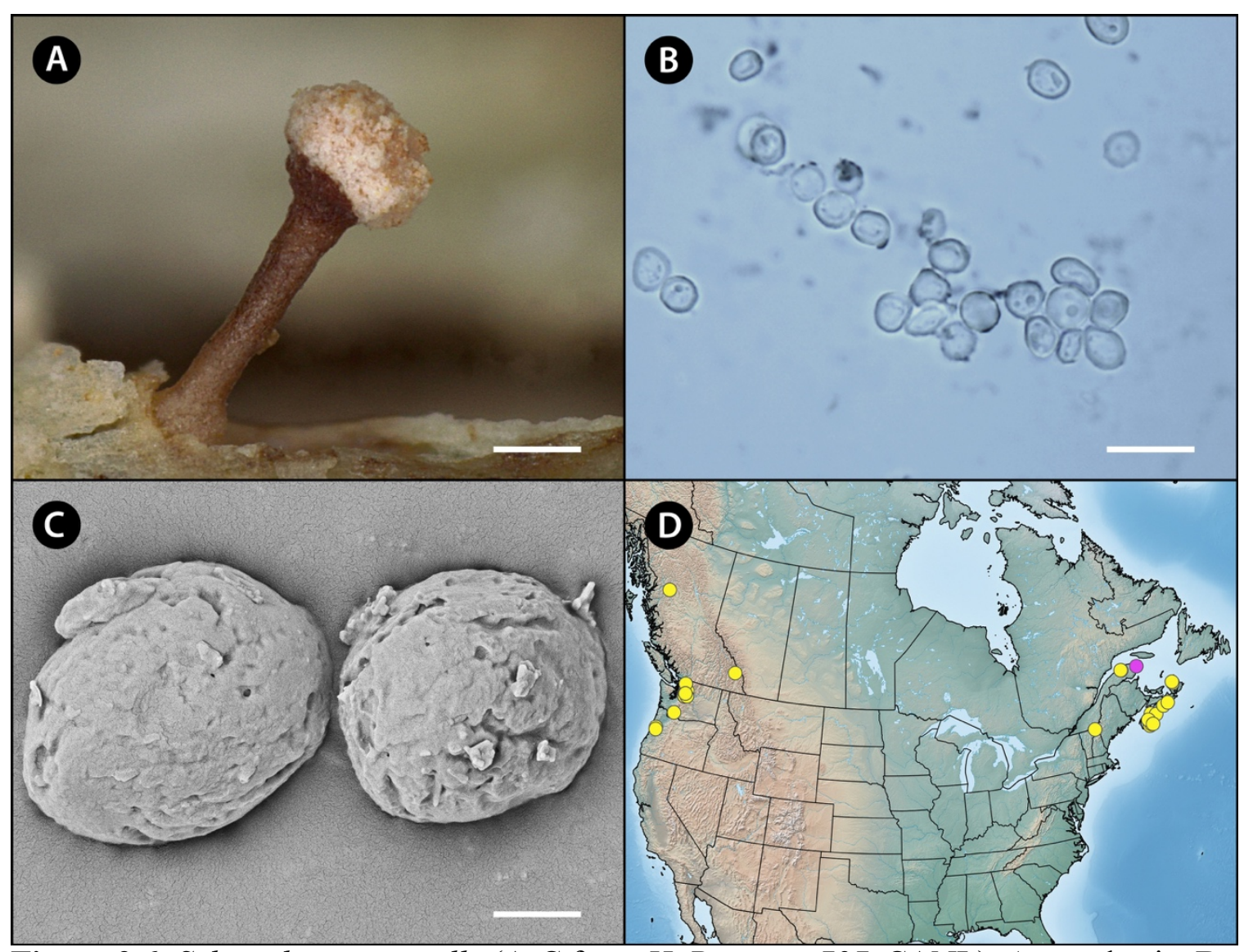

Figure 3.6. Sclerophora peronella (A-C from H. Paquette 727, CANL). A, apothecia. B, ascospores viewed under compound microscope. $\mathbf{C}$, ascospores viewed under a scanning electron microscope. D, known North America geographic distribution (pink = Forillon occurrence, yellow $=$ other occurrences). Scales $=0.20 \mathrm{~mm}$ in $\mathrm{A}, 8 \mu \mathrm{m}$ in B, $1.0 \mu \mathrm{m}$ in C.

\subsection{Discussion}

We discovered a broad range of calicioid species in Forillon, and four of them are particularly notable: Calicium denigratum, Chaenothecopsis oregana, Sclerophora coniophaea, and S. peronella. Calicium denigratum (Fig. 3.4) was recently reported from North America for the first time by McMullin et al. (2012). Those authors listed four occurrences in northern Ontario and one from New Brunswick. Our discovery is the first record for Quebec, the sixth specimen on the continent, and expands its range eastward. Chaenothecopsis oregana (Fig. 3.3) was previously known in North America from Washington State (21 occurrences) and was recently reported for the first time in Canada 
by Haughland and Martel (2016) from a single site at Lesser Slave Lake, Alberta. Our collection is the second record in Canada and the first in eastern North America. Due to this large range extension, we suspect that it may be more widespread in North America than originally postulated by Rikkinen (2003). Sclerophora coniophaea (Fig. 3.5) was first reported in North America from British Columbia (Goward et al. 1996) and has since been found on the east coast of Canada in New Brunswick and Nova Scotia, where it is considered rare (Selva 2014, Selva \& Tibell 1999). Here, we report it for the first time in Quebec. Sclerophora peronella (Fig. 3.6) is listed by the Canadian Species at Risk Act as 'special concern' (Government of Canada 2019). In Canada, it is known from thirteen occurrences in Nova Scotia (COSEWIC 2014, McMullin 2018, Selva 2014). In British Columbia, where it was reported for the first time in North America (Goward et al. 1996), it is known from two sites (COSEWIC 2014). However, only one of the British Columbia sites is extant (COSEWIC 2014). It is a globally rare species (COSEWIC 2014, Selva 2014) that was only recently reported from Quebec for the first time from a single collection at PNG (McMullin 2018).

Other studies of calicioids in northeastern North America have reported greater numbers of species, but all covered larger areas. McMullin and Arsenault (2016) located 32 calicioid species in eight forest stands throughout Newfoundland. In PNG, 53 calicioid species are known (McMullin unpublished data), but that park is more than three times the size of Forillon ( $802 \mathrm{~km} 2$ vs. $244.8 \mathrm{~km} 2)$ and the landscape is more diverse (McMullin et al. 2017b). In the Acadian Forest Ecoregion, which covers most of the Maritime Provinces in Canada and New England in the U.S.A., 89 calicioid species were reported by Selva (2014). He spent over 30 years studying the calicioids of this large 
area.

The southern Appalachians are a well-documented hotspot for lichen diversity (Lendemer et al. 2013). Selva (2016) reported 54 calicioid species from Great Smoky Mountains National Park (hereafter GSMNP) in that region. Forillon is part of the northernmost portion of the Appalachians in continental North America, and there is limited knowledge about the lichen biota of this region. Though we discovered fewer species (30) compared to Selva's work in GSMNP, it covers a much larger area (2120 km2 vs. $244.8 \mathrm{~km} 2$ ) and contains considerably more tree species (i.e., potential calicioid substrates) (Selva 2016, Whittaker 1956).

Our results broaden the understanding of calicioid richness in the northern Appalachian Mountains and establish a starting point from which to monitor and compare species presence between the north and south. Our study also adds to the notable work on calicioids in PNG led by one of us (R.T.M.) on the Gaspé Peninsula, and more broadly adds to the body of knowledge of Appalachian lichens (e.g., Selva 2013, 2014, 2016; Allen \& Lendemer 2016b; Lendemer et al. 2013). Despite a few well studied areas, calicioids remain understudied in much of North America, yet their value in conservation monitoring and management is considerable (Goward \& Arsenault 2018, Hardman et al. 2017, McMullin et al. 2008, Petersen et al. 2017, Selva 2003, Tibell 1992) and they warrant additional attention. 


\section{Chapter 4: Conclusions}

exactly.

Our curiosity is supposed to have limits, though these have never been defined (Margaret Atwood 1988, p. 39)

\subsection{General}

I discovered a broad range of calicioid lichens and fungi and macrolichens during my study in Forillon. In total, I report 170 taxa from the park; 169 species and two subspecies, from 48 genera, including 17 species from past collections. Over 50\% (90 taxa) of the taxa reported here are new records for the park. The evidence presented in Chapters 2 and 3 regarding the available data on lichen diversity in the Gaspé region and the northern Appalachians support the hypothesis that our knowledge of the lichen ecology in eastern Canada remains incomplete. The results of my study expand this knowledge, as do the dichotomous identification keys created and presented in Appendices A and B. Detailed discussions of the results of my study are presented in Chapters 2 and 3 (sections 2.7 and 3.7, respectively).

\subsection{Study limitations}

All objectives outlined in Chapter 1 were achieved during my project; however, there were limitations. During my field surveys there were two areas of the park that were not examined, the northwest corner of the park and the restricted areas of the cliffs around the presqu'ile of Forillon (i.e., the upper sections of the coastal cliffs at the point of the peninsula). After discussing the major vegetation types and consulting vegetation maps with the park ecologist (Daniel Sigouin), I elected to not visit the deep interior of the northwest corner of the park as 1) all vegetation types in Forillon were represented in the west, central, northeast and southeast areas of the park which were accessible by 
existing trail networks and/or by off trail expeditions that did not require traversing private property, and 2) no notable mesohabitat features were marked in this area. The restricted zones along the coastal cliffs were not accessible due to equipment limitations and safety concerns - rappelling was required to examine the upper areas of the coastal cliffs. As an alternative, I sought out exposed cliffs with similar habitat, including 1) along the Mont St. Alban Cliffs on the northeast side of the presqu'ile (facing Cap Bon Ami) (Location 27C in Appendix A), 2) unnamed cliffs on the south side of QC-132 where it traverses the park (across from the La Chute trailhead)(Location 5 in Appendix A) and 3) the lower sections of the coastal cliffs at Cap Gaspe where large sections of the rocks of the upper cliffs had fallen to the beach (Location 3C in Appendix A).

Three of the specimens collected during my study could not be identified to species: H.A. Paquette 695, 871, 635. H.A. Paquette 695, 871 are in the genus, Usnea, and appear to be $U$. substerilis or U. lapponica. However, the morphology of these specimens clearly has characteristics of both species (see notes in annotated checklist of macrolichen species in Appendix A.2). A search for more characteristic specimens during future surveys may resolve this identification. One additional specimen, H.A. Paquette 635, was only identified to the genus Tuckermanopsis. This specimen does not contain any lichen substances (confirmed using TLC) and has laminal apothecia, a combination of features not found in any of the currently available literature for this genus (Brodo et al. 2001, Esslinger 1973, Hinds \& Hinds 2007, Kärnfelt 1979). It may represent a novel taxon. These three specimens have been included in the key to the macrolichens (Appendix A.3) as ' Usnea sp. 1' and 'Tuckermanopsis sp. 1'. 
One additional limitation was specimen availability; I was unable to obtain the voucher for one species, Umbilicaria vellea, which has a single, unpublished collection from Forillon (D. \& D. Ladd 8861, MOR). The genus Umbilicaria occurs on noncalcareous rocks, such as granite (Brodo et al. 2001). Suitable substrate in Forillon is limited to glacial erratics (St-Amour 1985). However, Roed (1979) noted that no granitic glacial erratics were known from the park and suggested that if they did exist "the most favourable place to search for such erratics would be in the uplands of the northeastern part of the park" (pg. 52). I only encountered a single granitic boulder (in the fields above the beaches at Cap Des Rosiers, congruent with Roed's prediction) and it did not harbor any macrolichen species on it. Due to the lack of potential substrate in Forillon, this collection may be a misidentification, and since it is unavailable, it was not included in the keys or annotated species list.

\subsection{Future research opportunities}

The baseline lichen data I have established for the lichens in Forillon allow at least two interesting questions to be addressed during future research in the park and Quebec. The first is establishing provincial conservation status ranks in Quebec.

Biodiversity and floristic lichen studies in Canada often include conservation status ranks (e.g., McMullin 2015; McMullin and Lendemer 2013, 2016). However, this was not possible for my study, as Quebec is the only province in Canada that does not have conservation status ranks (NatureServe 2019). Conservation status ranks are non-legal designations that evaluate species extinction or extirpation risk (NatureServe 2019). NatureServe provides guidelines for the development of provincial, national and global rankings that can be applied to species with well-understood distributions. Development 
of provincial conservation status ranks in Quebec for lichens could inform conservation management planning and should be endeavoured. The results from Forillon will be an important part of calculating lichen status ranks as the Gaspé Peninsula is known for its rare flora (Parks Canada 1983), including lichens (McMullin \& Dorin 2016, McMullin et al. 2017b). The second question that can be addressed with these baseline data is whether species presence/absence within the park changes, which could indicate affects from climate change, fluctuations in air quality or changes in forest stand structure.

Future studies should also include the microlichens (crustose growth forms) of the park. This group typically accounts for 50-60\% of lichen diversity (Gowan \& Brodo 1988, McMullin 2015, Spribille et al. 2010). They are an often-overlooked group and their inclusion would be a valuable contribution to understanding the lichen flora of Forillon and the Gaspé region. 


\section{Appendices}

Appendix A Supplementary items referenced in Chapter 2 


\section{A.1 Location and habitat descriptions for the macrolichen collection sites in Forillon National Park}

Table A.1.1. Descriptions of the macrolichen collection sites in Forillon National Park. Location numbers and habitat description letters correspond with collection numbers in the Annotated checklist of macrolichen species of Forillon National Park in the proceeding appendix (A.2) and the waypoints listed in Table A.1.2.

\begin{tabular}{|c|c|c|}
\hline Location No. & Location Description & Habitat Description \\
\hline 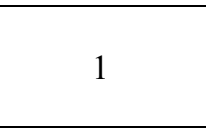 & Beaudry Creek & $\begin{array}{l}\text { Banks and riparian area of creek; upstream is wetland area, surrounded by coniferous forest, } \\
\text { downstream is narrow stream (1.5-3 m wide) with scrubby Salix and Alnus along banks. Banks are } \\
\text { rocky (calcareous) with some moss coverage. }\end{array}$ \\
\hline 2 & Cap Des Rosiers & $\begin{array}{l}\text { A: Pebble beach, eastern exposure to Gulf of St. Lawrence. Sedimentary rock cliffs at back of beach; } \\
\text { large sedimentary rocks scattered on beach, including imported rip-rap for wharf, and exposed coarse } \\
\text { sandstone at water's edge. Scattered driftwood. B: Open fields above pebble beach, including } \\
\text { campground; eastern exposure to the Gulf of St. Lawrence. Soil is sandy and dry. Vegetation } \\
\text { dominated by tall grasses and prickly wild rose (Rosa acicularis), with isolated stands of Picea, } \\
\text { Populus, and Betula. }\end{array}$ \\
\hline 3 & Cap Gaspe & $\begin{array}{l}\text { A: Alpine meadow with Picea, Abies, and Alnus; southern exposure to Gulf of St. Lawrence, eastern } \\
\text { aspect. B: Land's End lighthouse grounds; open grassy area, highly exposed. C: Coastal cliffs and } \\
\text { pebble beach; calcareous rock. }\end{array}$ \\
\hline 4 & Chemin du Cap Bon Ami & $\begin{array}{l}\text { A: Mature conifer-dominant forest; Picea and Abies. B: Open field across from campground; lone, } \\
\text { mature Picea glauca and lone medium-sized Acer sp. C: Forest along edge of coastal cliffs; Betula, } \\
\text { Picea, Abies. }\end{array}$ \\
\hline 5 & Cliffs south of QC-132 & $\begin{array}{l}\text { Cliffs; calcareous, northeastern aspect, humid and shaded. Thuja occidentalis growing at base of } \\
\text { exposed cliff; below cliffs wet, moss covered scree slope, many deciduous saplings. }\end{array}$ \\
\hline 6 & $\begin{array}{l}\text { Dobel Roberts House Heritage } \\
\text { Site }\end{array}$ & $\begin{array}{l}\text { Open field behind house; loan, mature apple tree (Malus sp.). Moderate southwest aspect, exposed to } \\
\text { Gaspe Bay. }\end{array}$ \\
\hline 7 & English Creek & $\begin{array}{l}\text { Creek from bridge on Le Portage Trail upstream; gravelly banks with sandy sections hosting stands } \\
\text { of Populus balsamifera, Alnus and Cornus. Sunny. }\end{array}$ \\
\hline 8 & $\begin{array}{c}\text { Forillon National Park } \\
\text { Operations Centre }\end{array}$ & $\begin{array}{l}\text { Wetland with standing Thuja occidentalis snags; exposed stream and pools, tall grasses dominate in } \\
\text { surrounding area that is not submerged. Full sun exposure. }\end{array}$ \\
\hline 9 & La Chute Trail & $\begin{array}{l}\text { A: Mature mixed-forest; Acer, Betula, Abies, Thuja occidentalis. B: Mature Acer saccharum forest. } \\
\text { C: Banks and base of waterfall; moss covered gravelly slope; mature Thuja occidentalis stand; humid } \\
\text { and shaded. }\end{array}$ \\
\hline
\end{tabular}




\begin{tabular}{|c|c|c|}
\hline Location No. & Location Description & Habitat Description \\
\hline 10 & La Vallee Trail & $\begin{array}{l}\text { A: Wetland dominated by Salix, Alnus and Cornus. Few Thuja occidentalis and Picea. Sunny. B: } \\
\text { Mixed-mature forest, dominated by Betula and Populus. C: Picnic shelter; south-facing with conifer- } \\
\text { dominated forest behind and open grassy area in front, bordered by shrubby Alnus and Cornus. D: } \\
\text { Wet Thuja occidentalis forest, abundant large Thuja occidentalis snags. }\end{array}$ \\
\hline 11 & Lac au Renard & $\begin{array}{l}\text { A: Forest dominated by Abies balsamea and Picea. Understory full; dominated by deciduous } \\
\text { saplings (Acer spicatum and Betula), ferns and bunch berries. Wet and shaded. B: Mixed-mature } \\
\text { forest; wet and shaded; bank along edge of trail eroding, revealing tree roots. }\end{array}$ \\
\hline 12 & Le Portage Trail (north) & $\begin{array}{l}\text { Ditch bank with exposed shale along trail; moss covering shale where not eroded, shaded by bushes } \\
\text { growing above. }\end{array}$ \\
\hline 13 & Le Portage Trail (south) & $\begin{array}{l}\text { A: Mature Acer forest; some mature Betula interspersed. Understory open; humid and shady. B: } \\
\text { Open field; south aspect; few loan, exposed trees and large Acer around field edges. }\end{array}$ \\
\hline 14 & $\begin{array}{l}\text { Le Portage Trail prescribed burn } \\
\text { between La Grande Cavee and } \\
\text { English Creek }\end{array}$ & $\begin{array}{l}\text { Prescribed burn site for Pinus strobus; Abies balsamea, Acer, and Betula with few large Pinus } \\
\text { strobus. Severe south aspect; gravelly soil. }\end{array}$ \\
\hline 15 & $\begin{array}{l}\text { Le Portage Trail prescribed burn } \\
\text { northeast of English Creek }\end{array}$ & $\begin{array}{l}\text { Prescribed burn site for Quercus rubra; few large Quercus, mostly conifer saplings growing from } \\
\text { burned areas. Moderate southwest aspect. }\end{array}$ \\
\hline 16 & Les Cretes Trail (east of QC-132) & Large, mature Thuja occidentalis stand; very wet and shady. \\
\hline 17 & $\begin{array}{l}\text { Les Cretes Trail (northwest of } \\
\text { QC-132) }\end{array}$ & $\begin{array}{l}\text { A: Forest dominated by Abies, Acer and Betula, understory dominated by ferns. Very wet (ground } \\
\text { soft and muddy) and shaded. B: Forest dominated by Abies balsamea, Betula, Picea and Sorbus; } \\
\text { understory primarily creeping juniper (Juniperus horizontalis). Severe south aspect; soil gravelly. C: } \\
\text { Populus tremuloides stand in exposed clearing; apparent dried up pond (exposed cracking mud and } \\
\text { some rocks, virtually no vegetation). Full sun exposure. D: Mature mixed-forest; Betula and Picea } \\
\text { dominant. Understory is filled in with ferns, bunch berries and Acer saplings. E: Trailside; shrubby } \\
\text { and exposed. Ground is wet and moss-covered. F: Mature mixed-forest; Abies, Betula, Picea and } \\
\text { Thuja occidentalis. Understory is open but shaded. G: Deciduous-dominant forest: Acer and Betula } \\
\text { of various sizes. Ground wet, shaded. H: Mature conifer forest, adjacent to wetland. Shaded. I: } \\
\text { Ridgeline, dominated by conifers. Understory open with needles and moss, many exposed roots. }\end{array}$ \\
\hline 18 & Les Graves Trail & $\begin{array}{l}\text { A: Shrubby, mixed vegetation along trail through open field above Gaspe Bay. Alnus, Cornus and } \\
\text { Picea dominate woody vegetation. B: Mixed forest: Abies balsamea and Betula papyrifera; } \\
\text { understory is closed in. C: Conifer dominant; small diameter Abies balsamea, Picea mariana and } \\
\text { Thuja occidentalis. Understory is open. }\end{array}$ \\
\hline 19 & $\begin{array}{l}\text { Les Lacs - the north lake of Lacs } \\
\text { de Penouille }\end{array}$ & $\begin{array}{l}\text { Approximately } 3 \text { metres from water's edge; small diameter conifers and shrubs dominate dry, peaty. } \\
\text { Gravelly ground with some moss-coverage. Sunny. }\end{array}$ \\
\hline 20 & $\begin{array}{l}\text { Les Lacs the middle lake of Lacs } \\
\text { de Penouille }\end{array}$ & $\begin{array}{l}\text { Moss-covered rock outcrop ca. 1-2 metres from water's edge on east shore of lake. Soil is sandy and } \\
\text { dry; lake shore is rocky and transitions to conifer forest } 2-3 \text { metres from water's edge. }\end{array}$ \\
\hline
\end{tabular}




\begin{tabular}{|c|c|c|}
\hline Location No. & Location Description & Habitat Description \\
\hline 21 & $\begin{array}{l}\text { Les Lacs the south lake of Lacs } \\
\text { de Penouille }\end{array}$ & $\begin{array}{l}\text { A: Shoreline of lake; rocky with scattered driftwood and standing snags. Conifers dominate beyond } \\
\text { the rocky shoreline. Sunny. B: Ridgeline, dominated by conifers. Understory open with needles and } \\
\text { moss, many exposed roots. C: Stream entering lake from the north; ca. } 1 \text { metre width, shaded with } \\
\text { moss-covered banks. Surrounding forest is dominated by Betula. }\end{array}$ \\
\hline 22 & $\begin{array}{l}\text { Les Lacs Trail between Beaudry } \\
\text { Creek and the north lake of Lacs } \\
\text { de Penouille }\end{array}$ & Mixed forest: Abies balsamea, Acer saccharum, Betula and Picea. \\
\hline 23 & $\begin{array}{l}\text { Les Lacs Trail between Le } \\
\text { Portage junction and IAT } \\
\text { camping shelter }\end{array}$ & $\begin{array}{l}\text { A: Conifer dominated stand; understory is crowded with ferns and Acer saplings. B: Mature mixed- } \\
\text { forest: Abies balsamea and Betula dominate. Mossy, shaded and wet. }\end{array}$ \\
\hline 24 & $\begin{array}{l}\text { Les Lacs Trail between QC-197 } \\
\text { and first lookout }\end{array}$ & $\begin{array}{l}\text { A: Mature mixed-forest: Abies, Acer, Betula } \text { and Picea; shaded. B: Mixed forest: Abies balsamea, } \\
\text { Acer saccharum, Betula and Picea; steep; trailside is moss-covered shale. C: Deciduous-dominant } \\
\text { forest: Acer } \text { and Betula. Understory is open, scattered saplings. Shaded. D: Exposed calcareous rock; } \\
\text { south facing. Moss-cover along ledge, exposed and eroding on face. Surrounding forest is dominated } \\
\text { by deciduous tree species. E: Wet Thuja occidentalis forest, abundant large Thuja occidentalis snags. }\end{array}$ \\
\hline 25 & $\begin{array}{l}\text { Les Lacs Trail north section, after } \\
\text { first lookout }\end{array}$ & Mature deciduous-forest: Acer and Betula. Understory open, scattered Acer saplings. Shaded. \\
\hline 26 & Les Parages Trail & Conifer-dominant forest; southwest facing. \\
\hline 27 & $\begin{array}{l}\text { Mont Saint Alban Cliffs } \\
\text { (northeast) }\end{array}$ & $\begin{array}{l}\text { A: Deciduous-dominant forest: Betula and Acer spicatum; moderate east aspect. B: Thuja } \\
\text { occidentalis-dominated forest with many snags; severe east aspect; ground loose rock and gravel } \\
\text { with moss-covering. C: Exposed calcareous cliffs; full sun and east exposure to Gulf of St. } \\
\text { Lawrence. }\end{array}$ \\
\hline 28 & $\begin{array}{l}\text { Mont Saint Alban Loop } \\
\text { (northeast) }\end{array}$ & $\begin{array}{l}\text { A: Conifer-dominant forest; understory open with groundcover of moss. B: Exposed, large Picea } \\
\text { glauca at coastal cliff edge; eastern exposure to Gulf of St. Lawrence. C: Exposed calcareous rock; } \\
\text { east facing; moss growing at top and along rocks; wet and shaded. }\end{array}$ \\
\hline 29 & $\begin{array}{l}\text { Mont Saint Alban Loop } \\
\text { (southwest) }\end{array}$ & $\begin{array}{l}\text { A: Wetland surrounded by large Thuja occidentalis. B: Conifer-dominant forest; ground dry and } \\
\text { gravelly; southwest aspect. C: Rockwall along small creek; sedimentary; some moss-coverage on } \\
\text { ledges; slight south aspect. }\end{array}$ \\
\hline 30 & Penouille Sandspit & $\begin{array}{l}\text { A: Exposed Picea mariana stand; ground is sandy; exposed. B: Sand dunes; Picea and Populus, } \\
\text { intermixed with blueberry bushes (Vaccinium sp.). Sunny. C: Sandy area dominated by lichen; some } \\
\text { conifers interspersed. Sunny. D: Boreal forest: Picea mariana dominate; moss and needle } \\
\text { groundcover; shaded. E: Sandy area dominated by lichen; some Picea and Populus interspersed. } \\
\text { Sunny. F: Sandy beach with large driftwood and dune grasses. Small Picea and Populus scattered. }\end{array}$ \\
\hline 31 & Petit Gaspe Campground & mpsite \#99; conifer-dominated stand with single, large Betula. \\
\hline
\end{tabular}




\begin{tabular}{|c|c|l|}
\hline Location No. & Location Description & \multicolumn{1}{c|}{ Habitat Description } \\
\hline 32 & $\begin{array}{r}\text { Riviere de L'Anse aux Griffon } \\
\text { east of Le Portage Trail }\end{array}$ & $\begin{array}{l}\text { Small creek (ca. 1 m wide); shaded; rocks in creek and on bank are moss covered. Series of riffles, } \\
\text { small waterfalls and deep pools. Water is very clear, almost no sediment. In some areas, rockwalls } \\
\text { are tall (ca. 4-5 m) creating moist microclimate. }\end{array}$ \\
\hline 33 & Tower Mountain Road & $\begin{array}{l}\text { A: Access road from QC-132 up to Tower Mountain; northern aspect, soil gravelly, forest mixed } \\
\text { (Abies, Acer spicatum, Betula, Picea, Sorbus). B: Exposed, shrubby forest along ridge overlooking } \\
\text { Cap Bon Ami; trees are small and predominantly coniferous. }\end{array}$ \\
\hline
\end{tabular}


Table A.1.2. Macrolichen collection sites in Forillon National Park. Global Positioning System (GPS) coordinates are given in Decimal Degrees and were recorded in North American Datum 1983 (NAD83). The waypoint numbers correspond with collection numbers in the Annotated checklist of macrolichen species of Forillon National Park in the proceeding appendix (A.2) and the location and habitat descriptions in Table A.1.1.

\begin{tabular}{|c|c|c|c|c|}
\hline Waypoint No. & Latitude & Longitude & Elevation (m.) & Location/Habitat \\
\hline 1 & 48.805218 & -64.239846 & 95 & 29B \\
\hline 2 & 48.797202 & -64.225278 & 97 & $29 \mathrm{~B}$ \\
\hline 3 & 48.806700 & -64.222109 & 99 & $28 \mathrm{~A}$ \\
\hline 4 & 48.798118 & -64.227479 & 118 & $29 \mathrm{~B}$ \\
\hline 5 & 48.804826 & -64.221557 & 167 & $28 \mathrm{~A}$ \\
\hline 6 & 48.814894 & -64.231218 & 221 & $29 \mathrm{~A}$ \\
\hline 7 & 48.812802 & -64.228029 & 284 & $28 \mathrm{~A}$ \\
\hline 8 & 48.811834 & -64.222392 & 74 & $4 \mathrm{C}$ \\
\hline 9 & 48.825526 & -64.227990 & 78 & $4 \mathrm{~A}$ \\
\hline 10 & 48.825478 & -64.227915 & 81 & $4 \mathrm{~A}$ \\
\hline 11 & 48.814977 & -64.223958 & 83 & $4 \mathrm{~B}$ \\
\hline 12 & 48.812831 & -64.222758 & 91 & 4B \\
\hline 13 & 48.818447 & -64.225984 & 117 & $4 \mathrm{~A}$ \\
\hline 14 & 48.789163 & -64.221334 & 24 & $18 \mathrm{~A}$ \\
\hline 15 & 48.793301 & -64.223028 & 38 & 6 \\
\hline 16 & 48.790878 & -64.219736 & 79 & 26 \\
\hline 17 & 48.791568 & -64.220564 & 81 & 18B \\
\hline 18 & 48.804228 & -64.220316 & 131 & $28 \mathrm{~B}$ \\
\hline 19 & 48.804463 & -64.220492 & 144 & $28 \mathrm{C}$ \\
\hline 20 & 48.845060 & -64.266668 & 42 & $9 \mathrm{~A}$ \\
\hline 21 & 48.844734 & -64.267769 & 65 & 9B \\
\hline 22 & 48.834509 & -64.278414 & 208 & $17 \mathrm{~A}$ \\
\hline 23 & 48.836835 & -64.281472 & 268 & 17B \\
\hline 24 & 48.853721 & -64.420019 & 2 & $30 \mathrm{~B}$ \\
\hline 25 & 48.853283 & -64.421435 & 3 & $30 \mathrm{C}$ \\
\hline 26 & 48.854758 & -64.415763 & 9 & $30 \mathrm{~A}$ \\
\hline 27 & 48.754099 & -64.168481 & 87 & $18 \mathrm{C}$ \\
\hline 28 & 48.957882 & -64.464192 & 93 & $24 \mathrm{~A}$ \\
\hline 29 & 48.951621 & -64.473930 & 192 & $24 \mathrm{~B}$ \\
\hline 30 & 48.951433 & -64.473648 & 197 & $24 \mathrm{~B}$ \\
\hline 31 & 48.949840 & -64.475681 & 211 & $24 \mathrm{~B}$ \\
\hline 32 & 48.949396 & -64.475773 & 219 & $24 \mathrm{~B}$ \\
\hline 33 & 48.945590 & -64.476394 & 278 & 24B \\
\hline
\end{tabular}




\begin{tabular}{|c|c|c|c|c|}
\hline Waypoint No. & Latitude & Longitude & Elevation (m.) & Location/Habitat \\
\hline 34 & 48.945842 & -64.469254 & 323 & 25 \\
\hline 35 & 48.923571 & -64.325938 & 12 & $10 \mathrm{~A}$ \\
\hline 36 & 48.918357 & -64.331010 & 36 & 10B \\
\hline 37 & 48.905010 & -64.336851 & 37 & $10 \mathrm{C}$ \\
\hline 38 & 48.831478 & $\begin{array}{l}-64.215781 \\
\end{array}$ & 3 & $2 \mathrm{~A}$ \\
\hline 39 & 48.831736 & -64.215867 & 9 & $2 \mathrm{~A}$ \\
\hline 40 & 48.953048 & -64.471418 & 159 & $24 \mathrm{C}$ \\
\hline 41 & 48.952103 & -64.472772 & 189 & $24 \mathrm{~B}$ \\
\hline 42 & 48.845637 & -64.266530 & 47 & $9 \mathrm{~A}$ \\
\hline 43 & 48.845491 & -64.266776 & 53 & 9B \\
\hline 44 & 48.843960 & -64.265731 & 59 & $9 \mathrm{~A}$ \\
\hline 45 & 48.844904 & -64.268303 & 94 & 9B \\
\hline 46 & 48.940257 & -64.457907 & 304 & $11 \mathrm{~A}$ \\
\hline 47 & 48.937596 & $\begin{array}{l}-64.456699 \\
\end{array}$ & 310 & $11 \mathrm{~B}$ \\
\hline 48 & 48.928078 & -64.466819 & 326 & 1 \\
\hline 49 & 48.947787 & -64.480507 & 260 & $24 \mathrm{~B}$ \\
\hline 50 & 48.947547 & -64.480048 & 264 & $24 \mathrm{C}$ \\
\hline 51 & 48.946645 & $\begin{array}{l}-64.479297 \\
\end{array}$ & 289 & $24 \mathrm{D}$ \\
\hline 52 & 48.92451 & -64.44624 & 340 & 23 \\
\hline 53 & 48.806869 & -64.254497 & 41 & 31 \\
\hline 54 & 48.834309 & -64.270864 & 210 & $33 \mathrm{~A}$ \\
\hline 55 & 48.834826 & -64.262848 & 271 & $33 \mathrm{~A}$ \\
\hline 56 & 48.834559 & -64.260509 & 309 & $33 \mathrm{~A}$ \\
\hline 57 & 48.834510 & -64.256170 & 361 & $33 \mathrm{~B}$ \\
\hline 58 & 48.874452 & -64.395303 & 289 & $19 \mathrm{~A}$ \\
\hline 59 & 48.890236 & -64.407000 & 409 & $22 \mathrm{~A}$ \\
\hline 60 & 48.906663 & $\begin{array}{l}-64.349670 \\
\end{array}$ & 23 & 7 \\
\hline 61 & 48.906853 & -64.350882 & 23 & 7 \\
\hline 62 & 48.879761 & -64.377701 & 157 & $15 \mathrm{~A}$ \\
\hline 63 & 48.839961 & -64.212597 & 6 & $2 \mathrm{~A}$ \\
\hline 64 & 48.896044 & -64.413705 & 423 & $22 \mathrm{C}$ \\
\hline 65 & 48.892502 & -64.408326 & 426 & $22 \mathrm{~B}$ \\
\hline 66 & 48.888563 & -64.404559 & 431 & 19B \\
\hline 67 & 48.899844 & -64.415960 & 436 & 20 \\
\hline 68 & 48.957871 & -64.463806 & 87 & $24 \mathrm{~A}$ \\
\hline 69 & 48.948397 & -64.478720 & 217 & $24 \mathrm{E}$ \\
\hline 70 & 48.859131 & $\begin{array}{l}-64.379982 \\
\end{array}$ & 130 & 8 \\
\hline 71 & 48.894548 & -64.412605 & 411 & $22 \mathrm{~A}$ \\
\hline
\end{tabular}




\begin{tabular}{|c|c|c|c|c|}
\hline Waypoint No. & Latitude & Longitude & Elevation (m.) & Location/Habitat \\
\hline 72 & 48.911017 & -64.423240 & 481 & 21 \\
\hline 73 & 48.914094 & -64.426071 & 490 & $11 \mathrm{~A}$ \\
\hline 74 & 48.813526 & -64.225280 & 103 & $27 \mathrm{~A}$ \\
\hline 75 & 48.813380 & -64.226391 & 197 & $27 \mathrm{~B}$ \\
\hline 76 & 48.813334 & -64.226997 & 203 & $27 \mathrm{C}$ \\
\hline 77 & 48.853652 & -64.428854 & 4 & $30 \mathrm{C}$ \\
\hline 78 & 48.853177 & -64.429380 & 5 & $30 \mathrm{C}$ \\
\hline 79 & 48.852969 & -64.423397 & 8 & $30 \mathrm{C}$ \\
\hline 80 & 48.852589 & -64.436926 & 8 & $30 \mathrm{D}$ \\
\hline 81 & 48.853636 & -64.429603 & 9 & $30 \mathrm{D}$ \\
\hline 82 & 48.859171 & -64.331182 & 271 & $17 \mathrm{C}$ \\
\hline 83 & 48.869302 & -64.347776 & 378 & 17D \\
\hline 84 & 48.868775 & -64.356112 & 380 & $17 \mathrm{E}$ \\
\hline 85 & 48.829601 & -64.217544 & 6 & $2 \mathrm{~B}$ \\
\hline 86 & 48.834638 & -64.279383 & 210 & $17 \mathrm{~F}$ \\
\hline 87 & 48.848162 & -64.319745 & 211 & $17 \mathrm{G}$ \\
\hline 88 & 48.847961 & -64.317538 & 214 & $17 \mathrm{G}$ \\
\hline 89 & 48.849103 & -64.304783 & 277 & $17 \mathrm{H}$ \\
\hline 90 & 48.840299 & -64.284821 & 360 & 17B \\
\hline 91 & 48.845564 & -64.297035 & 372 & 17I \\
\hline 92 & 48.847220 & -64.300626 & 389 & 17I \\
\hline 93 & 48.842320 & -64.287794 & 391 & 17I \\
\hline 94 & 48.829032 & -64.223648 & 10 & $2 \mathrm{~B}$ \\
\hline 95 & 48.851917 & -64.428777 & 3 & $30 \mathrm{D}$ \\
\hline 96 & 48.851938 & -64.436861 & 4 & $30 \mathrm{C}$ \\
\hline 97 & 48.853178 & -64.436455 & 5 & $30 \mathrm{E}$ \\
\hline 98 & 48.852343 & -64.424259 & 5 & $30 \mathrm{C}$ \\
\hline 99 & 48.849257 & -64.436365 & 7 & $30 \mathrm{~F}$ \\
\hline 100 & 48.851110 & -64.427541 & 7 & $30 \mathrm{E}$ \\
\hline 101 & 48.828828 & -64.261813 & 248 & 16 \\
\hline 102 & 48.929503 & -64.323087 & 13 & 14 \\
\hline 103 & 48.927209 & -64.321043 & 15 & $10 \mathrm{D}$ \\
\hline 104 & 48.918284 & -64.349598 & 183 & 12 \\
\hline 105 & 48.918981 & -64.349338 & 193 & 13 \\
\hline 106 & 48.844090 & -64.267492 & 84 & $9 \mathrm{C}$ \\
\hline 107 & 48.845595 & -64.269090 & 109 & $9 \mathrm{~B}$ \\
\hline 108 & 48.841047 & -64.267786 & 187 & 5 \\
\hline 109 & 48.882806 & -64.373309 & 144 & $15 \mathrm{~B}$ \\
\hline
\end{tabular}




\begin{tabular}{|c|c|c|c|c|}
\hline Waypoint No. & Latitude & Longitude & Elevation (m.) & Location/Habitat \\
\hline 110 & 48.871259 & -64.379968 & 160 & $32 \mathrm{~A}$ \\
\hline 111 & 48.811509 & -64.243074 & 132 & $29 \mathrm{C}$ \\
\hline 112 & 48.750530 & -64.162010 & -8 & $3 \mathrm{C}$ \\
\hline 113 & 48.751725 & -64.163196 & 33 & $3 \mathrm{~A}$ \\
\hline 114 & 48.751431 & -64.161438 & 37 & $3 \mathrm{~A}$ \\
\hline 115 & 48.751087 & -64.162254 & 94 & $3 \mathrm{~B}$ \\
\hline 116 & 48.853662 & -64.421557 & 5 & $30 \mathrm{E}$ \\
\hline 117 & 48.855116 & -64.414665 & 5 & $30 \mathrm{~F}$ \\
\hline 118 & 48.871747 & -64.379095 & 169 & $32 \mathrm{~A}$ \\
\hline 119 & 48.853807 & -64.425834 & 9 & $30 \mathrm{D}$ \\
\hline
\end{tabular}




\section{A.2 Annotated checklist of macrolichen species of Forillon National Park}

The following list is organized alphabetically by genus and species. Bolded numbers or number/letter combinations correspond with the collection sites in Table A.1.1. Numbers in parenthesis following collection numbers correspond with the waypoints in Table A.1.2. New reports for Canada are preceded by a dagger $(\dagger)$. New reports for Quebec are preceded by an asterisk $(*)$. Species collected for the first time in the park are preceded by a plus sign $(+)$ and non-bolded species are past collections only and were verified by the authors but not rediscovered during our study. Nomenclature follows Esslinger (2018) and any divergences reflect the opinions of the authors.

Authorities follow Brummitt \& Powell (1996) where possible, and Esslinger (2018) otherwise.

+Alectoria sarmentosa (Ach.) Ach. - Corticolous. 1.ix.2018: 22B - H.A. Paquette 414 (65) (CANL). Abies balsamea. 1.ix.2018: 22B - H.A. Paquette 413 (65) (CANL). 4.ix.2018: 11A - H.A. Paquette 532 (73) (CANL). Betula sp. 7.ix.2018: 17D - H.A. Paquette 621 (83) (CANL). Picea sp. 4.ix.2018: 21 - H.A. Paquette 537 (72) (CANL).

Anaptychia crinalis (Schleich.) Vězda ex J.Nowak - Corticolous on Picea sp. 9.ix.2018: 2B - H.A. Paquette 636 (85) (CANL). Picea glauca. 20.viii.2017: 4B - H.A. Paquette 96 (11) (CANL), ver.: R.T. McMullin; H.A. Paquette 95 (11) (CANL), ver.: I.M. Brodo. Saxicolous, calcareous. 15.ix.2018: 5 - H.A. Paquette 769 (108) (CANL). 20.ix.2018: 3C - H.A. Paquette 834 (112) (CANL).

Baeomyces rufus (Huds.) Rebent. - Saxicolous. 21.viii.2018: 3A - H.A. Paquette 159 (114) (CANL).

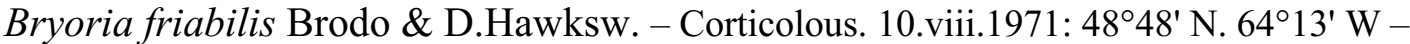
Brodo 18678 (CANL). NOTE.: this is the paratype for this species.

Bryoria furcellata (Fr.) Brodo \& D.Hawksw. - Corticolous. 26.viii.2018: 33A - H.A. Paquette 277 (55) (CANL). 6.ix.2018: 30C - H.A. Paquette 592 (79) (CANL). Conifer snag. 3.ix.2018: 8 - H.A. Paquette 485 (70) (CANL). Abies balsamea, snag. 20.viii.2017: 4A - H.A. Paquette 46 (13) (CANL). Picea sp. 23.ix.2018: 30D - H.A. Paquette 894 (119) (CANL). Lignicolous. 3.ix.2018: 8 - H.A. Paquette 500 (70) (CANL). Driftwood. 12.ix.2018: 30F - H.A. Paquette 697 (99) (CANL). 
Bryoria fuscescens (Gyeln.) Brodo \& D.Hawksw. - Corticolous. 6.ix.2018: 30C - H.A. Paquette 591 (79) (CANL). Picea sp. 26.viii.2018: 31 - H.A. Paquette 275A (53) (CANL). 2.ix.2018: 24E - H.A. Paquette 463 (69) (CANL). 7.ix.2018: 17C - H.A. Paquette 618 (82) (CANL). 10.ix.2018: 17H - H.A. Paquette 657A (89) (CANL). 21.ix.2018: 30F - H.A. Paquette 879 (117) (CANL). Picea glauca. 24.viii.2018: 1 - H.A. Paquette 251A (48) (CANL), ver.: I.M. Brodo. Lignicolous on Thuja occidentalis snag. 3.ix.2018: 8 - H.A. Paquette 487 (70) (CANL), ver.: I.M. Brodo. NOTES.: Our collections of this species include the dark (almost black in some cases), wiry form of this species formerly known as $B$. lanestris but now considered congruous with $B$. fuscescens based on molecular work by Velmala et al. 2014.

Bryoria kockiana Velmala, Myllys \& Goward - Lignicolous. 3.ix.2018: 8 - H.A. Paquette 475 (70) (CANL), ver.: R.T. McMullin.

Bryoria nadvornikiana (Gyeln.) Brodo \& D.Hawksw. - Corticolous on Abies balsamea. 10.ix.2018: 17I - H.A. Paquette 658 (92) (CANL). Picea sp. 27.viii.2018: 22A - H.A. Paquette 335 (59) (CANL). 2.ix.2018: 24E - H.A. Paquette 464 (69) (CANL). 7.ix.2018: 17C - H.A. Paquette 617 (82) (CANL). 14.ix.2018: 10C - H.A. Paquette 744 (37) (CANL), ver.: I.M. Brodo. 21.ix.2018: 30E - H.A. Paquette 876 (116) (CANL).

Bryoria pikei Brodo \& D.Hawksw. - Corticolous on Abies balsamea. 23.ix.2018: 30D H.A. Paquette 891 (119) (CANL). Picea sp. 6.ix.2018: 30C - H.A. Paquette 1001 (77) (CANL), det.: I.M. Brodo. 14.ix.2018: 10C - H.A. Paquette 744B (37) (CANL), det.: I.M. Brodo; H.A. Paquette 744C (37) (CANL). Picea glauca. 6.ix.2018: 30C - H.A. Paquette 590 (79) (CANL). Picea mariana. 24.viii.2017: 30A - H.A. Paquette 60 (26) (CANL), det.: R.T. McMullin.

+Bryoria salazinica Brodo \& D.Hawksw. - Corticolous on Picea mariana. 24.viii.2017: 30A - H.A. Paquette 59 (26) (CANL), det.: R.T. McMullin.

FIGURE 2.4 A-B. NOTES. - We confirmed the presence of salazinic acid in this specimen using thin-layer chromatography. In addition to its unique chemistry, this species is characterized by smooth, olivaceous branches that often have a twisted or curling appearance (Brodo \& Hawksworth 1977). This species appears to be endemic to northeastern North America where it is rare.

Bryoria simplicior (Vain.) Brodo \& D.Hawksw. - Corticolous on Picea sp. 26.viii.2018: 31 - H.A. Paquette 275B (53) (CANL), ver.: R.T. McMullin, I.M. Brodo. Picea glauca. 21.ix.2018: 30E - H.A. Paquette 866 (100) (CANL).

Bryoria trichodes subsp. trichodes (Michx.) Brodo \& D.Hawksw. - Corticolous. 27.viii.2018: 19A - H.A. Paquette 305 (58) (CANL). Conifer. 10.ix.2018: 17H - H.A. Paquette 656 (89) (CANL). Abies balsamea. 27.viii.2018: 22A - H.A. Paquette 334 (59) (CANL), ver.: I.M. Brodo. Picea sp. 27.viii.2018: 22A - H.A. Paquette 333 (59) (CANL). 1.ix.2018: 20 - H.A. Paquette 429B (67) (CANL); H.A. Paquette 432 (67) (CANL). 10.ix.2018: 17H - H.A. Paquette 657B (89) (CANL). 20.ix.2018: 3A - H.A. 
Paquette 845 (114) (CANL). Picea glauca. 24.viii.2018: 1 - H.A. Paquette 251B (48) (CANL). 21.ix.2018: 30E - H.A. Paquette 867 (100) (CANL).

+ Cetraria ericetorum subsp. ericetorum Opiz - Terricolous on sandy soil. 12.ix.2018: 30C - H.A. Paquette 686 (96) (CANL).

+Cetraria islandica subsp. crispiformis (Räsänen) Kärnefelt - Terricolous on sand. 12.ix.2018: 30C - H.A. Paquette 683 (98) (CANL).

Cladonia acuminata (Ach.) Norrl. - Terricolous. 17.vi.1971: 4851' N, 64²6' W - M.M. Grandtner 7879/L1 (CANL).

+Cladonia bellidiflora (Ach.) Schaer. - Lignicolous on roof of kitchen shelter. 11.ix.2018: 2B - H.A. Paquette 1002 (94) (CANL).

+Cladonia cenotea (Ach.) Schaer. - Lignicolous on decomposing driftwood. 12.ix.2018: 30F - H.A. Paquette 712 (99) (CANL).

Cladonia chlorophaea (Flörke ex Sommerf.) Spreng. - Bryicolous. 21.viii.2018: 24C H.A. Paquette 157 (40) (CANL). 22.viii.2017: 17A - H.A. Paquette 12 (22) (CANL), det.: R.T. McMullin. 9B - H.A. Paquette 193 (43) (CANL). 23.viii.2018: 1 - H.A. Paquette 218 (48) (CANL). Corticolous on snag. 21.viii.2017: 26 - H.A. Paquette 123 (16) (CANL). Lignicolous on snag. 21.viii.2017: 26 - H.A. Paquette 128 (16) (CANL), det.: R.T. McMullin. 25.viii.2017: 18C - H.A. Paquette 5 (27) (CANL). 27.viii.2017: 10A - H.A. Paquette 9 (35) (CANL). Terricolous. 24.viii.2017: 30B - H.A. Paquette 6 (24) (CANL), det.: R.T. McMullin. 27.viii.2018: 22A - H.A. Paquette 326 (59) (CANL).

Cladonia coniocrea (Flörke) Spreng. - Bryicolous. 26.vi.1972: 4855' N, 64²9' W Majcen 8343/L3 (2/3) (CANL).

Cladonia cornuta subsp. cornuta (L.) Hoffm. - Terricolous on sandy soil. 24.viii.2017: 30B - H.A. Paquette 2 (24) (CANL). 6.ix.2018: 30C - H.A. Paquette 585 (79) (CANL), ver.: R.T. McMullin. Sand. 6.ix.2018: 30C - H.A. Paquette 605 (78) (CANL), ver.: R.T. McMullin.

Cladonia crispata var. crispata (Ach.) Flot. - Lignicolous on roof of picnic shelter. 27.viii.2017: 10C - H.A. Paquette 126 (37) (CANL). Terricolous on sand. 6.ix.2018: 30C - H.A. Paquette 606 (78) (CANL).

Cladonia cristatella Tuck. - Lignicolous on roof of kitchen shelter. 11.ix.2018: 2B H.A. Paquette 1003 (94) (CANL); H.A. Paquette 1004 (94) (CANL). Terricolous on sand. 12.ix.2018: 30C - H.A. Paquette 678 (98) (CANL).

Cladonia cryptochlorophaea Asah. - Terricolous. 14.vii.1971: 4851' N, 64²6' W - Majcen 7873/L2 (CANL). 
Cladonia deformis (L.) Hoffm. - Terricolous. 26.vi.1972: 4854' N, 64³0' W - Majcen 8349/L2 (2/3) (CANL).

+Cladonia ecmocyna subsp. ecmocyna Leight. - Terricolous on sand. 6.ix.2018: 30C H.A. Paquette 607 (78) (CANL). 12.ix.2018: 30C - H.A. Paquette 677 (98) (CANL).

+Cladonia furcata (Huds.) Schrad. - Terricolous. 6.ix.2018: 30C - H.A. Paquette 581 (79) (CANL). Sandy soil. 24.viii.2017: 30B - H.A. Paquette 13 (24) (CANL).

+Cladonia gracilis subsp. gracilis (L.) Willd. - Bryicolous. 6.ix.2018: 30D - H.A. Paquette 600 (81) (CANL).

Cladonia gracilis subsp. turbinata (Ach.) Ahti - Corticolous on decomposing bark. 3.ix.2018: 8 - H.A. Paquette 506 (70) (CANL). Lignicolous on roof of kitchen shelter. 11.ix.2018: 2B - H.A. Paquette 1005 (94) (CANL).

+Cladonia labradorica Ahti \& Brodo - Terricolous. 12.ix.2018: 30C - H.A. Paquette 685 (96) (CANL), ver.: T. Ahti.

FIGURE 2.4 C-D.

NOTES. - This specimen contains usnic acid (confirmed with TLC), and thick, heavily perforated branches with no apothecia. The inner walls of the stalks are smooth, and it lacks soredia and isidia. This species appears to be endemic to northeastern North America (T. Ahti pers. comm.).

+Cladonia macilenta var. bacillaris (Ach.) Schaer. - Lignicolous on roof of picnic shelter. 27.viii.2017: 10C - H.A. Paquette 20 (37) (CANL); H.A. Paquette 125 (37) (CANL).

Cladonia maxima (Asah.) Ahti - Bryicolous. 6.ix.2018: 30D - H.A. Paquette 601 (81) (CANL). 10.ix.2018: 17I - H.A. Paquette 659 (92) (CANL).

Cladonia merochlorophaea Asah. - Terricolous on sand. 14.vi.1975: 48 $51^{\prime} \mathrm{N}, 64^{\circ} 25^{\prime} \mathrm{W}-$ Brodo 20748 (CANL).

Cladonia mitis Sandst. - Bryicolous. 1.ix.2018: 20 - H.A. Paquette 442 (67) (CANL). 6.ix.2018: 30C - H.A. Paquette 583 (79) (CANL). Lignicolous on roof of picnic shelter. 27.viii.2017: 10C - H.A. Paquette 129 (37) (CANL). Terricolous on sandy soil. 24.viii.2017: 30B - H.A. Paquette 17 (24) (CANL), ver.: R.T. McMullin.

Cladonia multiformis G. Merr. - Terricolous on sand. 12.ix.2018: 30C - H.A. Paquette 679 (98) (CANL).

Cladonia ochrochlora Flörke - Bryicolous. 22.viii.2017: 17A - H.A. Paquette 11 (22) (CANL), ver.: R.T. McMullin. 
+Cladonia phyllophora Ehrh. ex Hoffm. - Terricolous on sand. 12.ix.2018: 30C - H.A. Paquette 681 (98) (CANL), det.: R.T. McMullin.

Cladonia pyxidata (L.) Hoffm. - Bryicolous. 9.vii.1972: 4850'30" N, 64¹6' - M.M. Grandtner 7914/L3 (2/3) (CANL).

Cladonia pleurota (Flörke) Schaer. - Terricolous. 9.1x.2018: 20 - H.A. Paquette 428 (67) (CANL).

Cladonia rangiferina (L.) Weber ex F.H.Wigg. - Bryicolous. 6.ix.2018: 30C - H.A. Paquette 582 (79) (CANL). Terricolous on sandy soil. 24.viii.2017: 30B - H.A. Paquette 16 (24) (CANL). Sand. 24.viii.2017: 30C - H.A. Paquette 4 (25) (CANL). 12.ix.2018: 30C - H.A. Paquette 676 (98) (CANL).

+Cladonia rei Schaer. - Terricolous on sandy soil. 24.viii.2017: 30B - H.A. Paquette 3 (24) (CANL).

Cladonia scabriuscula (Delise) Nyl. - Terricolous. 6.ix.2018: 30C - H.A. Paquette 586 (79) (CANL) Gravel/sand. 19.viii.2017: 29B - H.A. Paquette 121 (1) (CANL), det.: R.T. McMullin. Sand. 12.ix.2018: 30C - H.A. Paquette 682 (98) (CANL).

Cladonia squamosa (Scop.) Hoffm. - Bryicolous. 27.viii.2018: 22A - H.A. Paquette $327 A$ (59) (CANL). 10.ix.2018: 17I - H.A. Paquette 660 (91) (CANL).

Cladonia stellaris (Opiz) Pouzar \& Vězda - Terricolous on sand. 24.viii.2017: 30C H.A. Paquette 14 (25) (CANL).

Cladonia sulphurina (Michx.) Fr. - Lignicolous on roof of picnic shelter. 27.viii.2017: 10C - H.A. Paquette 19 (37) (CANL). Decomposing wood. 3.ix.2018: 8 - H.A. Paquette 507 (70) (CANL). Terricolous. 1.ix.2018: 20 - H.A. Paquette 426 (67) (CANL); H.A. Paquette 427 (67) (CANL). Sand. 6.ix.2018: 30C - H.A. Paquette 604 (78) (CANL).

Cladonia turgida Ehrh. ex Hoffm. - Terricolous on sandy soil. 12.ix.2018: 30D - H.A. Paquette 691 (80) (CANL), ver.: R.T. McMullin, N. v. Miltenburg.

Cladonia uncialis subsp. uncialis (L.) Weber ex F.H.Wigg. - Terricolous on sandy soil. 6.ix.2018: 30C - H.A. Paquette 584 (79) (CANL).

Cladonia verticillata (Hoffm.) Schaer. - Bryicolous. 26.viii.2017: 24B - H.A. Paquette 1 (31) (CANL), det.: R.T. McMullin.

+Collema furfuraceum (Schaer.) Du Rietz - Lignicolous on conifer snag. 19.ix.2018: 28B - H.A. Paquette 823 (18) (CANL).

+Collema nigrescens (Huds.) DC. - Corticolous on Acer saccharum. 26.viii.2017: 25 H.A. Paquette 71 (34) (CANL), ver.: F. Anderson. 
Collema subflaccidum Degel. - Corticolous on Acer sp., fallen. 28.viii.2018: 15A - H.A. Paquette 360 (62) (CANL). Deciduous. 7.ix.2018: 17C - H.A. Paquette 610 (82) (CANL). Acer rubrum. 21.viii.2017: 28B - H.A. Paquette 70 (18) (CANL), det.: R.T. McMullin.

+Dermatocarpon miniatum (L.) W.Mann - Saxicolous, limestone. 19.ix.2018: 29B H.A. Paquette 828 (4) (CANL).

+Dibaeis baeomyces (L.f.) Rambold \& Hertel - Terricolous on gravel/sand. 26.viii.2018: 33A - H.A. Paquette 302 (54) (CANL).

Evernia mesomorpha Nyl. - Corticolous on Abies balsamea. 19.viii.2017: 29B - H.A. Paquette 62 (2) (CANL). Lignicolous on roof of kitchen shelter. 11.ix.2018: 2B - H.A. Paquette 1006 (94) (CANL). Snag. 19.viii.2017: 28A - H.A. Paquette 52 (7) (CANL). NOTE.: one of the specimens collected (H.A. Paquette 1006) had distinctly isidioid soredia, this is not typical; however, this species is highly variable.

+Hypogymnia bitteri (Lynge) Ahti - Corticolous on conifer. 7.ix.2018: 17D - H.A. Paquette 622 (83) (CANL). Standing snag. 27.viii.2018: 22A - H.A. Paquette 329 (59) (CANL), ver.: R.T. McMullin.

Hypogymnia physodes (L.) Nyl. - Corticolous on Abies balsamea. 19.viii.2017: 28A H.A. Paquette 116 (7) (CANL). 20.viii.2017: 4A - H.A. Paquette 93 (9) (CANL). 22.viii.2018: 9A - H.A. Paquette 182 (42) (CANL). Abies balsamea, snag. 20.viii.2017: 4A - H.A. Paquette 119 (13) (CANL). Betula snag. 19.viii.2017: 28A - H.A. Paquette 82 (7) (CANL). Picea sp. 26.viii.2018: 33B - H.A. Paquette 295B (57) (CANL). 9.ix.2018: 2B - H.A. Paquette 645 (85) (CANL). Lignicolous. 3.ix.2018: 8 - H.A. Paquette 498 (70) (CANL). Bridge railing. 28.viii.2018: 7 - H.A. Paquette 366 (60) (CANL). Driftwood. 12.ix.2018: 30F - H.A. Paquette 702 (99) (CANL). Driftwood roots. 4.ix.2018: 22A H.A. Paquette 519 (71) (CANL). Snag. 19.viii.2017: 28A - H.A. Paquette 84 (7) (CANL). 3.ix.2018: 8 - H.A. Paquette 488 (70) (CANL).

+Hypogymnia subobscura (Vain.) Poelt - Lignicolous on roof of kitchen shelter. 11.ix.2018: 2B - H.A. Paquette 1007 (94) (CANL), det.: R.T. McMullin.

FIGURE 2.4 E-F. NOTES. - This specimen lacks both isidia and soredia. It does not have protocetraric and physodalic acids and its medullary ceiling is white/pale. This species has an Arctic affinity and is uncommon at this low latitude (Thomson 1984).

Hypogymnia tubulosa (Schaer.) Hav. - Corticolous on fallen branch. 23.viii.2018: 11B H.A. Paquette 205 (47) (CANL). Abies balsamea snag. 20.viii.2017: 4A - H.A. Paquette 51 (13) (CANL). Betula sp. fallen. 2.ix.2018: 24A - H.A. Paquette 469 (68) (CANL). Picea sp. 26.viii.2018: 33B - H.A. Paquette 295A (57) (CANL). 9.ix.2018: 2B - H.A. Paquette 644 (85) (CANL). Picea glauca. 21.viii.2017: 18A - H.A. Paquette 74 (14) (CANL). 6.ix.2018: 30C - H.A. Paquette 589 (79) (CANL). 
+Hypogymnia vittata (Ach.) Parrique - Corticolous on Picea sp. 23.viii.2018: 11A H.A. Paquette 201 (46) (CANL), ver.: R.T. McMullin.

+Imshaugia aleurites (Ach.) S.L.F.Mey. - Lignicolous. 3.ix.2018: 8 - H.A. Paquette 503 (70) (CANL). Driftwood. 27.viii.2018: 22A - H.A. Paquette 325 (59) (CANL). Driftwood roots. 4.ix.2018: 22A - H.A. Paquette 513 (71) (CANL). Roof of kitchen shelter. 11.ix.2018: 2B - H.A. Paquette 1008 (94) (CANL).

Lathagrium fuscovirens (With.) Otálora, P.M.Jørg. \& Wedin - Bryicolous. 10.viii.1971: $48^{\circ} 48^{\prime} \mathrm{N}, 64^{\circ} 13^{\prime} \mathrm{W}-$ Brodo 18659 (CANL).

Lathagrium undulatum (Laurer ex Flot.) Poetsch - Saxicolous, calcareous. 15.ix.2018: 5 - H.A. Paquette 778 (108) (CANL). 19.ix.2018: 29C - H.A. Paquette 818A (111) (CANL). Terricolous, calcareous. 5.ix.2018: 27C - H.A. Paquette 577 (76) (CANL); H.A. Paquette 576A (76) (CANL).

Leptogium acadiense J.W.Hinds, F.L.Anderson \& Lendemer - Corticolous on Populus sp. 28.viii.2018: 7 - H.A. Paquette 375 (61) (CANL).

FIGURE 2.5. C-D.

NOTES. - This species is endemic to northeastern North America (Stone et al. 2016).

Leptogium cyanescens (Ach.) Körb. - Bryicolous. 22.viii.2017: 9B - H.A. Paquette 69 (21) (CANL). 5.ix.2018: 27B - H.A. Paquette 544 (75) (CANL). 16.ix.2018: 32A - H.A. Paquette 787 (110) (CANL). Corticolous on Picea sp. 19.viii.2017: 28A - H.A. Paquette 22 (3) (CANL). Thuja occidentalis. 19.viii.2017: 29A - H.A. Paquette 40 (6) (CANL).

Leptogium lichenoides (L.) Zahlbr. - Bryicolous over rock. 22.ix.2018: 32A - H.A. Paquette 882 (118) (CANL), ver.: R.T. McMullin.

Lobaria pulmonaria (L.) Hoffm. - Corticolous on Picea sp. 19.viii.2017: 28A - H.A. Paquette 25 (3) (CANL). Picea glauca. 21.viii.2017: 28B - H.A. Paquette 26 (18) (CANL). Thuja occidentalis. 19.viii.2017: 29A - H.A. Paquette 43 (6) (CANL).

Lobaria quercizans Michx. - Corticolous on Acer saccharum. 26.viii.2017: 24B - H.A. Paquette 38 (29) (CANL).

+Lobaria scrobiculata (Scop.) P.Gaertn. - Corticolous on Acer saccharum. 26.viii.2017: 24B - H.A. Paquette 44 (32) (CANL).

Melanelixia glabratula (Lamy) Sandler \& Arup - Corticolous on Abies balsamea snag. 19.viii.2017: 4A - H.A. Paquette 110 (10) (CANL), ver.: R.T. McMullin.

Melanelixia subaurifera (Nyl.) O.Blanco, A.Crespo, Divakar, Ess1., D.Hawksw. \& Lumbsch - Corticolous on Abies balsamea snag. 20.viii.2017: 4A - H.A. Paquette 112 (13) (CANL). Acer sp. 28.viii.2018: 15A - H.A. Paquette 346 (62) (CANL). Acer saccharum. 21.viii.2017: 18B - H.A. Paquette100 (17) (CANL); H.A. Paquette 102 (17) 
(CANL). Betula alleghaniensis. 2.ix.2018: 24A - H.A. Paquette 472 (68) (CANL). Picea glauca. 21.viii.2017: 18A - H.A. Paquette 73 (14) (CANL). Lignicolous on Thuja occidentalis. 13.ix.2018: 16 - H.A. Paquette 721 (101) (CANL).

$\dagger+$ Melanohalea exasperata (De Not.) O.Blanco, A.Crespo, Divakar, Essl., D.Hawksw. \& Lumbsch - Corticolous on deciduous snag. 16.ix.2018: 15B - H.A. Paquette 797 (109) (CANL), ver.: R.T. McMullin.

FIGURE 2.5. A-B. NOTES. - This species is characterized by its lack of lichen substances (negative in all reactions), lack of isidia or soredia, and the abundance of cylindrical papillae that are topped with distinct white pseudocyphellae (Hinds \& Hinds 2007). Our collection is the first published report in Quebec and Canada, and the second confirmed collection of this species in Canada.

Melanohalea exasperatula (Nyl.) O.Blanco, A.Crespo, Divakar, Essl., D.Hawksw. \& Lumbsch 2004 - Corticolous on Picea glauca. 10.viii.1971: 48 48 $\mathrm{N}, 64^{\circ} 13^{\prime} \mathrm{W}-$ Brodo 18669 (CANL).

+Melanohalea olivacea (L.) O.Blanco, A.Crespo, Divakar, Essl., D.Hawksw. \& Lumbsch - Corticolous on Sorbus sp. 26.viii.2018: 33A - H.A. Paquette 278 (55) (CANL).

+Melanohalea septentrionalis (Lynge) O.Blanco, A.Crespo, Divakar, Essl., D.Hawksw. \& Lumbsch - Corticolous on Picea glauca. 21.ix.2018: 30E - H.A. Paquette 877 (116) (CANL).

Melanohalea trabeculata (Ahti) O.Blanco, A.Crespo, Divakar, Essl., D.Hawksw. \&

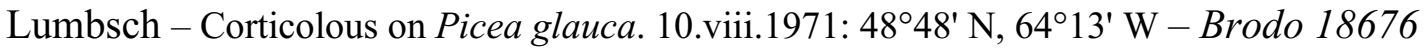
(CANL).

Nephroma bellum (Spreng.) Tuck. - Corticolous on Sorbus snag. 10.ix.2018: 17B - H.A. Paquette 662 (90) (CANL).

+Nephroma laevigatum Ach. - Bryicolous. 5.ix.2018: 27B - H.A. Paquette 543 (75) (CANL).

Nephroma parile (Ach.) Ach. - Bryicolous over rock. 14.ix.2018: 12 - H.A. Paquette 754 (104) (CANL).

+Pannaria rubiginosa (Thunb. ex Ach.) Delise - Corticolous on Thuja occidentalis, fallen. 3.ix.2018: 8 - H.A. Paquette 489 (70) (CANL)

+Parmelia fertilis Müll. Arg. - Corticolous deciduous snag. 15.ix.2018: 9B - H.A. Paquette 782 (107) (CANL). Betula alleghaniensis snag. 26.viii.2018: 33A-H.A. Paquette 470 (55) (CANL), ver.: R.T. McMullin.

FIGURE 2.5. E-F. 
NOTES. - This species lacks isidia or soredia and has squarrose rhizines (Hinds et al. 1998). Our report is the most northerly known occurrence of this species.

Parmelia saxatilis (L.) Ach. - Lignicolous on dead roots. 1.ix.2018: 20 - H.A. Paquette 424 (67) (CANL).

Parmelia squarrosa Hale - Corticolous on Abies balsamea. 19.viii.2017: 28A - H.A. Paquette 36 (7) (CANL). Abies balsamea snag. 20.viii.2017: 4A - H.A. Paquette 113 (13) (CANL). Acer saccharum. 20.viii.2017: 4B - H.A. Paquette 29 (12) (CANL); H.A. Paquette 30 (12) (CANL). 26.viii.2017: 24B - H.A. Paquette 45 (32) (CANL). 13.ix.2018: 17F - H.A. Paquette 730 (86) (CANL). Betula snag. 19.viii.2017: 28A - H.A. Paquette 83 (7) (CANL). 21.ix.2018: 30E - H.A. Paquette 873 (100) (CANL). Malus sp. 21.viii.2017: 6 - H.A. Paquette 78 (15) (CANL). Picea glauca. 21.viii.2017: 18A - H.A. Paquette 75 (14) (CANL); H.A. Paquette 76 (14) (CANL). Lignicolous on snag. 19.viii.2017: 28A - H.A. Paquette 87 (7) (CANL).

Parmelia sulcata Taylor - Corticolous on Picea glauca. 20.viii.2017: 4B - H.A. Paquette 99 (11) (CANL). 21.viii.2017: 18A - H.A. Paquette 77 (14) (CANL). Plastic (foghorn). 20.ix.2018L: 3B - H.A. Paquette 861 (115) (CANL).

+Parmeliella triptophylla (Ach.) Müll. Arg. - Bryicolous. 24.viii.2018: 24C - H.A. Paquette 235 (50) (CANL). Corticolous on Acer sp. 22.viii.2017: 9A - H.A. Paquette 37 (20) (CANL). Thuja occidentalis. 2.ix.2018: 24E - H.A. Paquette 450 (69) (CANL); H.A. Paquette 453 (69) (CANL). Thuja occidentalis snag. 3.ix.2018: 8 - H.A. Paquette 481 (70) (CANL).

Parmeliopsis ambigua (Wulfen) Nyl. - Corticolous. 27.viii.2018: 22A - H.A. Paquette 310 (59) (CANL). Abies balsamea. 24.viii.2018: 1 - H.A. Paquette 242 (48) (CANL). Lignicolous on driftwood roots. 4.ix.2018: 22A - H.A. Paquette 510 (71) (CANL); H.A. Paquette 511 (71) (CANL).

+Parmeliopsis capitata R.C.Harris ex J.W.Hinds \& P.L.Hinds - Corticolous. 6.ix.2018: 30C - H.A. Paquette 594 (79) (CANL). Conifer. 27.viii.2018: 22A - H.A. Paquette 331 (59) (CANL). Lignicolous on roof of kitchen shelter. 11.ix.2018: 2B - H.A. Paquette 1009 (94) (CANL).

+Parmeliopsis hyperopta (Ach.) Vain. - Corticolous on conifer. 27.viii.2018: 22A - H.A. Paquette 332 (59) (CANL). Lignicolous. 27.viii.2018: 22A - H.A. Paquette 311 (59) (CANL). 12.ix.2018: 30E - H.A. Paquette 694 (97) (CANL). Driftwood. 27.viii.2018: 22A - H.A. Paquette 324 (59) (CANL). 12.ix.2018: 30F - H.A. Paquette 400 (99) (CANL).

+Peltigera aphthosa (L.) Willd. - Bryicolous. 26.viii.2017: 24B - H.A. Paquette 63 (30) (CANL). 21.viii.2018: 24B - H.A. Paquette 164 (41) (CANL). 24.viii.2018: 24B - H.A. Paquette 1000 (49) (CANL). 5.ix.2018: 27B - H.A. Paquette 549 (75) (CANL). 
Peltigera canina (L.) Willd. - Bryicolous. 10.viii.1971: 4848' N, 64 $13^{\prime} \mathrm{W}$ - Brodo 18626 (CANL).

Peltigera degenii Gyeln. - Bryicolous. 5.viii.1972: Cap Bon-Ami campground - G. Savage 26 (CANL).

Peltigera elisabethae Gyeln. - Bryicolous. 19.viii.2017: 28A - H.A. Paquette 24 (3) (CANL). 23.viii.2018: 11A - H.A. Paquette 198 (46) (CANL). 16.ix.2018: 32A - H.A. Paquette 791 (110) (CANL).

+Peltigera extenuata (Nyl. ex Vain.) Lojka - Bryicolous. 12.ix.2018: 30D - H.A. Paquette 696 (80) (CANL), ver.: R.T. McMullin.

Peltigera horizontalis (Huds.) Baumg. - Bryicolous. 15.ix.2018: 9C - H.A. Paquette 786 (106) (CANL). 24.viii.2018: 24B - H.A. Paquette 270 (49) (CANL); H.A. Paquette 271

(49) (CANL). Bryicolous over calcareous rock. 26.viii.2017: 24A - H.A. Paquette 27

(28) (CANL). 5.ix.2018: 27A - H.A. Paquette 539 (74) (CANL).

Peltigera leucophlebia (Nyl.) Gyeln. - Bryicolous over rock. 1.ix.2018: 20 - H.A. Paquette 443 (67) (CANL).

+Peltigera malacea (Ach.) Funck - Terricolous on sand. 12.ix.2018: 30C - H.A. Paquette 680 (98) (CANL).

+Peltigera membranacea (Ach.) Nyl. - Bryicolous. 5.ix.2018: 27B - H.A. Paquette 550 (75) (CANL). 16.ix.2018: 32A - H.A. Paquette 788 (110) (CANL). 22.ix.2018: 32A H.A. Paquette 885 (118) (CANL).

Peltigera neopolydactyla (Gyeln.) Gyeln. - Bryicolous. 23.viii.2018: 11B - H.A. Paquette 209 (47) (CANL). 26.viii.2018: 33A - H.A. Paquette 300 (56) (CANL). 1.ix.2018: 19B - H.A. Paquette 446 (66) (CANL), det.: R.T. McMullin. 22C - H.A. Paquette 444 (64) (CANL). 21.ix.2018: 30D - H.A. Paquette 874 (95) (CANL)

+Peltigera praetextata (Flörke ex Sommerf.) Zopf - Bryicolous. 23.viii.2018: 11A H.A. Paquette 197 (46) (CANL). 26.viii.2017: 24B - H.A. Paquette 64 (33) (CANL). 4.ix.2018: 11A - H.A. Paquette 530 (73) (CANL). 7.ix.2018: 17C - H.A. Paquette 619 (82) (CANL). 17E - H.A. Paquette 624 (84) (CANL). Corticolous on root snag. 23.viii.2018: 1 - H.A. Paquette 215 (48) (CANL).

+Peltigera rufescens (Weiss) Humb. - Bryicolous. 6.ix.2018: 30C - H.A. Paquette 595 (79) (CANL). 12.ix.2018: 30D - H.A. Paquette 692 (80) (CANL). 14.ix.2018: 14 - H.A. Paquette 767 (102) (CANL). Terricolous on sandy soil. 12.ix.2018: 30D - H.A. Paquette 608 (80) (CANL). 30C - H.A. Paquette 675 (98) (CANL).

Phaeophyscia adiastola (Essl.) Essl. - Bryicolous over calcareous rock. 20.ix.2018: 3A H.A. Paquette 857 (113) (CANL). Corticolous on Picea glauca. 21.viii.2017: 18A - H.A. 
Paquette 72 (14) (CANL). Saxicolous, calcareous. 20.ix.2018: 3C - H.A. Paquette 836A (112) (CANL); H.A. Paquette 836 B (112) (CANL); H.A. Paquette 842 (112) (CANL).

Phaeophyscia decolor (Kashiw.) Essl. - Saxicolous. 5.viii.1972: Cap Bon-Ami campground G. Savage 43 (CANL).

Phaeophyscia hispidula (Ach.) Essl. - Corticolous. viii.1960: Cap Bon Ami - H.A. Imshaug 26482 (MSC).

+Phaeophyscia kairamoi (Vain.) Moberg - Bryicolous over calcareous rock.

21.viii.2017: 28C - H.A. Paquette 56 (19) (CANL). 19.ix.2018: 28C - H.A. Paquette 826 (19) (CANL).

Phaeophyscia orbicularis (Neck.) Moberg - Saxicolous. viii.1960: Cap Bon Ami - H.A. Imshaug 26467 (MSC).

+Phaeophyscia pusilloides (Zahlbr.) Essl. - Corticolous on Acer saccharum. 16.ix.2018: 15B - H.A. Paquette 794 (109) (CANL).

+Phaeophyscia rubropulchra (Degel.) Moberg - Corticolous on Acer sp. 28.viii.2018: 15A - H.A. Paquette 347 (62) (CANL); H.A. Paquette 359 (62) (CANL).

+Phaeophyscia sciastra (Ach.) Moberg - Saxicolous, calcareous. 20.ix.2018: 3C - H.A. Paquette 835 (112) (CANL).

+Physcia adscendens H.Olivier - Corticolous on Malus sp. 21.viii.2017: 6 - H.A. Paquette 80 (15) (CANL); H.A. Paquette 81 (15) (CANL). Lignicolous on driftwood. 12.ix.2018: 30F - H.A. Paquette 706 (99) (CANL); H.A. Paquette 708 (99) (CANL).

+Physcia alnophila (Vain.) Loht., Moberg, Myllys \& Tehler - Corticolous, deciduous. 26.viii.2018: 33B - H.A. Paquette 294 (57) (CANL), det.: R.T. McMullin.

+Physcia millegrana Degel. - Lignicolous on driftwood. 12.ix.2018: 30F - H.A. Paquette 707 (99) (CANL).

+Physcia stellaris (L.) Nyl. - Corticolous on Sorbus sp. 26.viii.2018: 33A - H.A. Paquette 471 (55) (CANL). Lignicolous on driftwood. 21.ix.2018: 30F - H.A. Paquette 880 (117) (CANL).

+Physcia tenella (Scop.) DC. - Saxicolous. 30.viii.2018: 2A - H.A. Paquette 391 (63) (CANL), ver.: R.T. McMullin.

+Physconia detersa (Nyl.) Poelt - Corticolous on Acer sp., fallen. 28.viii.2018: 15A H.A. Paquette 348 (62) (CANL). Acer saccharum. 20.viii.2017: 4B - H.A. Paquette 32 (12) (CANL). 10.ix.2018: 17G - H.A. Paquette 651 (87) (CANL). 16.ix.2018: 15B H.A. Paquette 793 (109) (CANL). Betula sp. 24.viii.2018: 24D - H.A. Paquette 262 (51) (CANL). Quercus rubra. 14.ix.2018 - H.A. Paquette 752 (105) (CANL). 
Placynthium nigrum (Huds.) Gray - Saxicolous on limestone. 10.viii.1971: 48 $48^{\prime} \mathrm{N}$, 641' W - Brodo 18655 (CANL). 19.ix.2018: 29C - H.A. Paquette 818B (111) (CANL), det.: R.T. McMullin.

+Platismatia glauca (L.) W.L.Culb. \& C.F.Culb. - Corticolous on Abies balsamea. 19.viii.2017: 28A - H.A. Paquette 117 (7) (CANL). Picea glauca. 19.viii.2017: 28A H.A. Paquette 91 (5) (CANL); H.A. Paquette 92 (5) (CANL). Juniperus horizontalis. 22.viii.2017: 17B - H.A. Paquette 65 (23) (CANL). Lignicolous. 3.ix.2018: 8 - H.A. Paquette 495 (70) (CANL). Roof of picnic shelter. 12.ix.2018: 30E - H.A. Paquette 714 (100) (CANL). Standing snag. 24.viii.2018: 23 - H.A. Paquette 249 (52) (CANL).

Protopannaria pezizoides (Weber) P.M.Jørg. \& S.Ekman - Bryicolous. 21.viii.2018: 24C - H.A. Paquette 135 (40) (CANL). 23.viii.2018: 11B - H.A. Paquette 207 (47) (CANL). 5.ix.2018: 27A - H.A. Paquette 542 (74) (CANL). 10.ix.2018: 17G - H.A. Paquette 654 (88) (CANL). 14.ix.2018: 10D - H.A. Paquette 733 (103) (CANL).

+Punctelia rudecta (Ach.) Krog - Corticolous on Acer saccharum, fallen. 15.ix.2018: 9B - H.A. Paquette 779 (45) (CANL).

Ramalina dilacerata (Hoffm.) Hoffm. - Corticolous on Abies balsamea snag. 20.viii.2017: 4A - H.A. Paquette 48 (13) (CANL). Picea glauca. 9.ix.2018: 2B - H.A. Paquette 634 (85) (CANL). Lignicolous. 4.ix.2018: 22A - H.A. Paquette 518 (71) (CANL).

Ramalina farinacea (L.) Ach. - Corticolous on Abies balsamea snag. 20.viii.2017: 4A H.A. Paquette 67 (13) (CANL). Picea sp. 19.viii.2017: 28A - H.A. Paquette 23 (3) (CANL). 21.viii.2017: 18A - H.A. Paquette 58 (14) (CANL). Picea glauca. 20.viii.2017: 4B - H.A. Paquette 97 (11) (CANL). 19.ix.2018: 28B - H.A. Paquette 824 (18) (CANL).

Ramalina roesleri (Hochst. ex Schaer.) Nyl. - Corticolous. 6.ix.2018: 30C - H.A. Paquette 593 (79) (CANL). Abies balsamea snag. 20.viii.2017: 4A - H.A. Paquette 49 (13) (CANL); H.A. Paquette 50 (13) (CANL). Picea sp. 19.viii.2017: 28A - H.A. Paquette 68 (3) (CANL). Picea glauca. 6.ix.2018: 30C - H.A. Paquette 588 (79) (CANL).

+Scytinium tenuissimum (Hoffm.) Otálora, P.M.Jørg. \& Wedin - Bryicolous. 4.ix.2018: 21 - H.A. Paquette 536B (72) (CANL).

*+Scytinium teretiusculum (Wallr.) Otálora, P.M.Jørg. \& Wedin - Bryicolous over rock. 16.ix.2018: 32A - H.A. Paquette 791 B (110) (CANL), det.: R.T. McMullin, J.C.

Lendemer.

FIGURE 2.6 A-B. NOTES. - This specimen lacks apothecia (they are usually uncommon in this species) and has abundant coralloid extensions, that look like isidia, growing from squamulose lobes (frequently obscuring the lobes) (Ahti et al. 2007, Hinds \& Hinds 2007). 
Stereocaulon condensatum Hoffm. - Terricolous on sand. 6.ix.2018: 30C - H.A. Paquette 598 (77) (CANL).

Stereocaulon paschale (L.) Hoffm. - Terricolous on sand. 24.viii.2017: 30C - H.A. Paquette 28 (25) (CANL), det.: R.T. McMullin. 21.ix.2018: 30E - H.A. Paquette 869 (100) (CANL).

+Stereocaulon tomentosum Fr. - Bryicolous. 4.ix.2018: 21 - H.A. Paquette 536A (72) (CANL), det.: R.T. McMullin. Saxicolous. 16.ix.2018: 32A - H.A. Paquette 792 (110) (CANL), det.: R.T. McMullin.

Tuckermanopsis sp. 1 - Corticolous on Picea glauca. 9.ix.2018: 2B - H.A. Paquette 635 (85) (CANL).

Appendix A.5. NOTES. - This specimen has laminal apothecia and lacks lichen substances. See Appendix for further discussion.

+Tuckermanopsis americana (Spreng.) Hale - Corticolous on Abies balsamea snag. 20.viii.2017: 4A - H.A. Paquette 111 (13) (CANL). Betula sp. snag. 21.ix.2018: 30E H.A. Paquette 872 (100) (CANL). Lignicolous. 3.ix.2018: 8-H.A. Paquette 499 (70) (CANL). Roof of kitchen shelter. 11.ix.2018: 2B - H.A. Paquette 1010 (94) (CANL).

Tuckermanopsis ciliaris (Ach.) Gyeln. - Corticolous on Betula sp. 26.viii.2018: 33A H.A. Paquette 276 (55) (CANL).

Tuckermanopsis orbata (Nyl.) M.J.Lai - Corticolous on conifer. 10.ix.2018: 17I - H.A. Paquette 661 (93) (CANL). Picea mariana. 24.viii.2017: 30A - H.A. Paquette 61 (26) (CANL).

+Tuckermanopsis sepincola (Hoffm.) Hale - Lignicolous. 27.viii.2018: 22A - H.A. Paquette 1011 (59) (CANL).

Usnea sp. 1 Gyeln. - Corticolous. 21.ix.2018: 30E - H.A. Paquette 695 (97) (CANL); H.A. Paquette 871 (100) (CANL).

NOTES. - These specimens contain usnic acid and traces amounts of salazinic acid (confirmed with TLC). The soralia are granular and mostly tuberculate as in $U$.

substerilis; however, some are distinctly excavate, wrapping around the entire branch and bearing cortical 'flaps' which is typical of $U$. lapponica (Goward 1999). In addition, $U$. substerilis usually has some isidiate soralia which were not observed in our specimens.

Usnea dasopoga (Ach.) Nyl. - Corticolous on Abies balsamea. 26.viii.2018: 33A - H.A. Paquette 283 (55) (CANL). 27.viii.2018: 22A - H.A. Paquette 338 (59) (CANL). Picea sp. 19.viii.2017: 29B - H.A. Paquette 55 (2) (CANL). 27.viii.2018: 22A - H.A. Paquette 336 (59) (CANL); H.A. Paquette 337 (59) (CANL). 2.ix.2018: 24E - H.A. Paquette 462 (69) (CANL). 14.ix.2018: 10C - H.A. Paquette 745 (37) (CANL); H.A. Paquette 746 
(37) (CANL). Picea glauca. 21.ix.2018: 30E - H.A. Paquette 865 (100) (CANL). Lignicolous on conifer snag. 27.viii.2017: 10B - H.A. Paquette 34 (36) (CANL). 22.viii.2018: 9A - H.A. Paquette 175 (44) (CANL).

+Usnea diplotypus Vain. - Corticolous on Betula sp. snag. 21.ix.2018: 30E - H.A. Paquette 870 (100) (CANL). Picea sp. 27.viii.2018: 22A - H.A. Paquette 318 (59) (CANL). Picea glauca. 24.viii.2018: 1 - H.A. Paquette 251C (48) (CANL).

Usnea longissima Ach. - Corticolous on Abies balsamea. 13.viii.1971: 48 $51^{\prime} \mathrm{N}, 64^{\circ}{ }^{2} 5^{\prime}$ $\mathrm{W}$ - Brodo 18731 B (CANL).

+Usnea scabrata Nyl. - Corticolous on Picea sp. 14.ix.2018: 10C - H.A. Paquette 747 (37) (CANL). Lignicolous on Thuja occidentalis snag. 3.ix.2018: 8 - H.A. Paquette 486 (70) (CANL).

+Usnea silesiaca Motyka - Corticolous on Abies balsamea. 1.ix.2018: 22B - H.A. Paquette 1014 (65) (CANL).

Usnea subfloridana Stirt. - Corticolous on Abies balsamea snag. 20.viii.2017: 4A - H.A. Paquette 47 (13) (CANL). Acer sp., fallen. 28.viii.2018: 15A - H.A. Paquette 361 (62) (CANL). Lignicolous on roof of kitchen shelter. 11.ix.2018: 2B - H.A. Paquette 1012 (94) (CANL).

+Vahliella leucophaea (Vahl) P.M.Jørg. - Saxicolous. 16.ix.2018: 32A - H.A. Paquette 790 (110) (CANL), det.: R.T. McMullin, J.C. Lendemer. 22.ix.2018: 32A - H.A. Paquette 888 (118) (CANL), det.: R.T. McMullin, J.C. Lendemer.

Vulpicida pinastri (Scop.) J.-E.Mattsson \& M.J.Lai - Corticolous on Abies balsamea. 19.viii.2017: 28A - H.A. Paquette 115 (7) (CANL). Thuja occidentalis. 2.ix.2018: 24E H.A. Paquette 474 (69) (CANL). Lignicolous on driftwood. 27.viii.2018: 22A - H.A. Paquette 313 (59) (CANL). Snag. 26.viii.2018: 33B - H.A. Paquette 293 (57) (CANL). Thuja occidentalis snag. 3.ix.2018: 8 - H.A. Paquette 501 (70) (CANL).

+Xanthomendoza hasseana (Räsänen) Søchting, Kärnefelt \& S.Y.Kondr. - Corticolous on Populus sp. 7.ix.2018: 17C - H.A. Paquette 614 (82) (CANL).

Xanthoria elegans (Link) Th. Fr. - Saxicolous. 20.ix.2018: 3C - H.A. Paquette 1015 (112) (CANL). Calcareous rocks. 28.viii.2017: 2A - H.A. Paquette 127A (39) (CANL). 28.viii.2017: 2A - H.A. Paquette 103 (38) (CANL). 30.viii.2018: 2A - H.A. Paquette 389 (63) (CANL); H.A. Paquette 394 (63) (CANL); H.A. Paquette 1013 (63) (CANL).

+Xanthoria parietina (L.) Th. Fr. - Corticolous on Picea sp. 9.ix.2018: 2B - H.A. Paquette 643 (85) (CANL). Populus tremuloides. 21.ix.2018: 30F - H.A. Paquette 878 (117) (CANL). 
Xanthoria polycarpa (Hoffm.) Rieber - Corticolous. 20.viii.2017: 4C - H.A. Paquette 118 (8) (CANL).

Xanthoria sorediata (Vain.) Poelt - Saxicolous. 10.viii.1971: $48^{\circ} 48^{\prime} \mathrm{N}, 64^{\circ} 13^{\prime} \mathrm{W}-$ Brodo 18663 (CANL). 


\section{A.3 Key to the macrolichens of Forillon National Park}

Characters and measurements in the keys are based on material from Forillon examined by the authors, unless otherwise cited.

\section{KEY TO THE GENERA}

1. Thallus fruticose.

1. Thallus foliose (including squamulose) ....................................................................

2. Sub-fruticose, erect foliose or microfruticose ..............................................................

2. Fruticose (i.e., stalked, pendant or tufted, and not distinctly dorsiventral) ....................6

3. Thallus appearing microfruticose due to abundant coralloid extensions (superficially resembling isidia) originating from and obscuring squamulose lobes; primary photobiont is cyanobacteria

3. Sub-fruticose, erect foliose; primary photobiont is algae ..............................................

4. Apothecia abundant, lecanorine with a burgundy disk; ascospores muriform (3 longitudinal septa and 5 transverse septa) and ca. 21 x $14 \mu \mathrm{m}$.........Scytinium tenuissimum 4. Apothecia absent. S. teretiusculum

5. Corticolous or saxicolous (on limestone); lobes with a grey-white upper cortex and an ecorticate channel along the lower surface; conspicuous pale grey cilia projecting from lobe margins; pseudocyphellae absent................................................. Anaptychia crinalis 5. Terricolous; lobes brown to tan with an upper and lower cortex; cilia not projecting from lobe margins; pseudocyphellae conspicuous CETRARIA

6. Thallus with cephalodia STEREOCAULON

6. Thallus without cephalodia 7

7. Primary thallus crustose; secondary thallus with biatorine apothecia atop short, robust

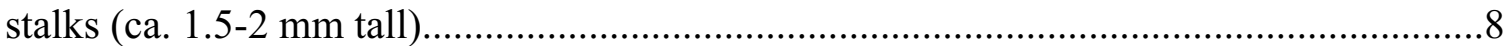

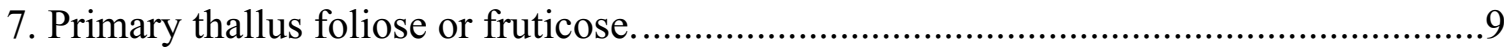

8. Primary thallus white to grey, medulla $\mathrm{PD}+$ yellow and $\mathrm{KOH}+$ yellow (baeomycesic acid); apothecia pink Dibaeis baeomyces 8. Primary thallus greenish, medulla $\mathrm{PD}+$ orange and $\mathrm{KOH}+$ yellow (stictic acid); apothecia red-brown. Baeomyces rufus

9. Branches covered in a thick, whitish, arachnoid tomentum and blue-grey phyllocladia S. tomentosum

9. Branches without a tomentum and phyllocladia .10 
10. Thallus stalked; branches/podetia hollow; usually terricolous

CLADONIA

10. Thallus tufted to pendant; branches hollow or not; corticolous or lignicolous.

11. Thallus pale brown to dark brown/blackish; KC- (usnic acid absent).

BRYORIA

11. Thallus green-yellow; $\mathrm{KC}+$ yellow (usnic acid)

12. Branches with central cord.

USNEA

12. Branches without central cord

13. Thallus distinctly pendant; corticolous; esorediate; pseudocyphellae abundant, raised and whitish Alectoria sarmentosa 13. Thallus clearly tufted; sorediate, or if esorediate, then branches hollow and perforated

14. Cortex limp, making thallus pliable; soredia coarse and developing along ridges, rarely becoming almost isidioid; apothecia absent Evernia mesomorpha 14. Cortex robust, thallus brittle when dry; sorediate or not, if sorediate then soredia developing in discrete soralia or terminally on branch tips; apothecia present or absent RAMALINA

15. Erect foliose, appearing sub-fruticose .16

15. Distinctly foliose (including squamulose), with clear differentiation between the upper and lower surface

16. Corticolous or saxicolous (on limestone); lobes with a grey-white upper cortex and an ecorticate channel along the lower surface; conspicuous pale grey cilia projecting from lobe margins; pseudocyphellae absent. Anaptychia crinalis 16. Terricolous; lobes brown to tan with an upper and lower cortex; cilia not projecting from lobe margins; pseudocyphellae conspicuous CETRARIA

17. Cyanobacterial photobiont (including lichens with cephalodia) .............................18

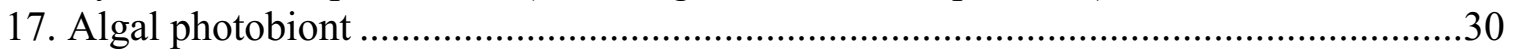

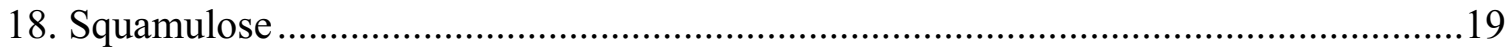

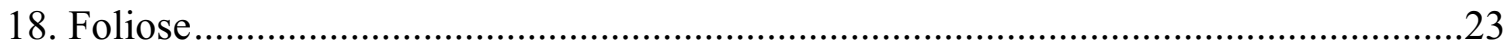

19. Thallus gelatinous when wet; with abundant isidioid growths growing from and obscuring tiny lobes ................................................... LEPTOGIUM \& SCYTINIUM

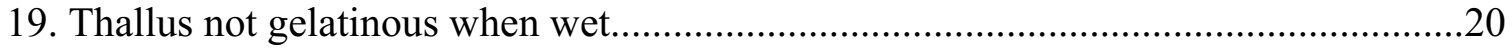

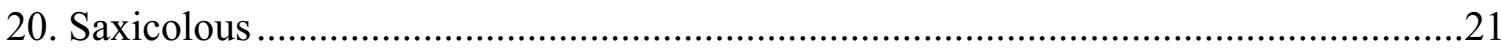

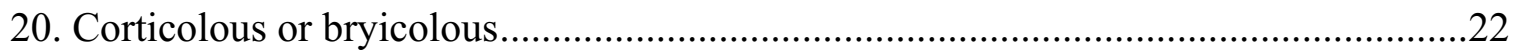

21. Ascospores non-septate, colourless, ellipsoidal and ca. 15 (13.8-15.3) $\mu \mathrm{m}$ long; robust blackish hypothallus; lobes greyish and roundish (ca. $0.5 \mathrm{~mm}$ ) with black hypothallus 
visible between lobes;

Vahliella leucophaea

21. Ascospores 1-2-septate, colourless, ellipsoidal and ca. 14 (10.7-15.3) $\mu \mathrm{m}$ long; conspicuous blue-black hypothallus; lobes brownish, branching in tiny rosettes, $<0.5 \mathrm{~mm}$ wide Placynthium nigrum

22. Non-isidiate; thallus grey-brown without an obvious hypothallus; medulla without lichen substances; ascospores simple, colourless, ca. $23 \mu \mathrm{m}$ long and heavily ornamented (visible at $400 \mathrm{X}$ magnification) Protopannaria pezizoides 22. Isidiate, often obscuring thallus of flat, grey squamules with conspicuous black hypothallus; corticolous; if fruiting, apothecia lecanorine, pale brown disks; thallus without lichen substances Parmeliella triptophylla

23. Thallus gelatinous when wet .24

23. Thallus not gelatinous when wet .25

24. Thallus not stratified COLLEMA \& LATHAGRIUM 24. Thallus stratified LEPTOGIUM \& SCYTINIUM

25 . Thallus with algal primary photobiont and cyanobacteria in cephalodia .26

25 . Thallus with cyanobacterial primary photobiont, cephalodia absent .27

26. Lower cortex pale and tomentose; cephalodia occurring on lower surface or internally (though visible as bumps on the lower surface). LOBARIA 26. Lacking lower cortex; cephalodia occurring on upper surface PELTIGERA

27. Thallus lacking a lower cortex; lower surface veined or with pattern of dark and light spots, sometimes unclear at margins PELTIGERA

27. Thallus with a lower cortex. .28

28. Thallus rosette forming, grey-brown with a bluish hypothallus .... Pannaria rubiginosa 28. Thallus typically ascending, not forming rosettes and without a hypothallus.....

29. Lower surface heavily tomentose; thallus yellowish-grey with reticulate ridges; bluish-grey soredia marginal and in laminal soralia Lobaria scrobiculata 29. Lower surface more or less smooth, if tomentose then minutely; thallus brown or bluish with or without wrinkles but never reticulate ridges; sorediate or not.. NEPHROMA

30. Thallus yellow or orange .31

30. Thallus shades of mineral grey, white, brown or charcoal 32

31. Soredia abundant, bright yellow and marginal; corticolous or lignicolous; medulla bright yellow Vulpicida pinastri 31. Sorediate or not; saxicolous or, if corticolous, then esorediate; medulla white XANTHORIA \& XANTHOMENDOZA

32. Thallus umbilicate (i.e. attached to substrate at a central anchor); perithecia dark 
brown dots across upper cortex; saxicolous on limestone

Dermatocarpon miniatum

33. Medulla orange, $\mathrm{KOH}+$ purple (skyrin); soredia coarsely granular, greenish and primarily marginal ............................................................................. rubropulchra 33. Medulla white, $\mathrm{KOH} \pm$ but never + purple (skyrin absent); sorediate or not ................34

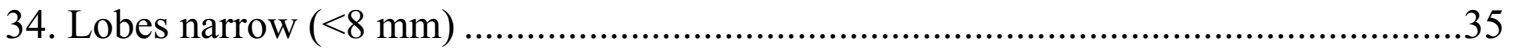

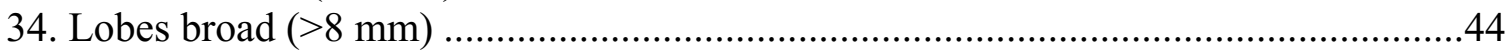

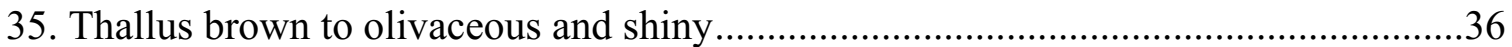

35. Thallus not both brown to olivaceous and shiny …….................................................3

36. Lobes closely appressed to substrate; if fruiting, then apothecia originating laminally on thallus MELANELIXIA \& MELANOHALEA 36. Lobes ascending, with a ruffled appearance; if fruiting, then apothecia originating from lobe margins, or rarely laminally TUCKERMANOPSIS

37. Lobes inflated, hollow; medulla $\mathrm{KC}+$ rose (physodalic acid) HYPOGYMNIA

37. Lobes not inflated, solid; medulla $\mathrm{KC}-$ .38

38. Cortex $\mathrm{KOH}+$ or $\mathrm{KC}+$... .39

38. Lichen substances absent, or with zeorin (negative in spot tests)... 43

39. Cortex KOH-, $\mathrm{KC}+$ (usnic acid) PARMELIOPSIS

39. Cortex $\mathrm{KOH}+$, $\mathrm{KC}$ - (without usnic acid). 40

40. Cortex $\mathrm{KOH}+$ yellow turning blood red, $\mathrm{PD}+$ orange (salazinic acid) PARMELIA 40. Cortex $\mathrm{KOH}+$ yellow, $\mathrm{PD} \pm$ .41

41. Cortex and medulla $\mathrm{KOH}+$ deep yellow, $\mathrm{PD}+$ orange, $\mathrm{UV}$ - (thamnolic acid); isidiate Imshaugia aleurites

41. Cortex $\mathrm{KOH}+$ yellow, $\mathrm{PD}$ - (atranorin); medulla $\mathrm{UV} \pm$; non-isidiate 42

42. Medulla and soredia both UV+ white (divaricaric acid) PARMELIOPSIS 42. Medulla and/or soredia UV- (without divaricaric acid)..... PHYSCIA

43. Thallus brownish-green with thick white pruina covering lobe tips; lower surface black with dense cushion of squarrose rhizines; marginal soralia greenish-brown; without lichen substances in cortex or medulla; corticolous ..... Physconia detersa 43. Thallus colour variable; lobes never pruinose; rhizines simple; sorediate or not; without lichen substances, or with zeorin only; saxicolous, bryicolous or corticolous PHAEOPHYSCIA

44. Cortex $\mathrm{KOH}-$ (protolichesterinic), or if $\mathrm{KOH}+$ yellow (atranorin) then also $\mathrm{UV}+$ bluewhite (alectoronic); thallus brown to olivaceous TUCKERMANOPSIS 
44. Cortex $\mathrm{KOH}+$ yellow (atranorin); thallus white to brownish or mineral blue-grey ....45

45. Medulla $\mathrm{KC}+$ red, $\mathrm{C}+$ red (lecanoric acid); thallus appressed to substrate, mineral blue-grey; abundant punctate white pseudocyphellae on upper surface; isidia cylindrical and laminal. Punctelia rudecta 45. Medulla without lichen substances; thallus ascending, appearing frilly, colour variable from almost white to greenish-pale brown; pseudocyphellae absent; isidia and/or soredia marginal and laminal Platismatia glauca

\section{KEY TO THE SPECIES}

\section{BRYORIA:}

1. Sorediate

1. Esorediate.

2. Lichen substances absent; thallus dark brown; pseudocyphellae absent

Bryoria simplicior

2. Lichen substance present, various; thallus colour light tan to black; pseudocyphellae present or absent

3. Cortex and medulla $\mathrm{PD}+$ yellow, $\mathrm{KOH}+$ yellow and $\mathrm{C} \pm$ pink (flash) (barbatolic acid and trace amounts of alectorialic acid); soralia PD+ red (fumarprotocetraric acid) and strongly bending branches; thallus tan to tan-grey B. nadvornikiana 3. Cortex and/or soralia C-, $\mathrm{KOH}-, \mathrm{PD}+$ red (fumarprotocetraric acid); thallus typically dark brown

4. Soralia with thorn-like isidia growing from them; cortex and medulla, including soralia $\mathrm{PD}+$ red (fumarprotocetraric acid); pseudocyphellae absent. ..B. furcellata 4. Soralia without isidia; thallus without lichen substances, however soralia PD+ orange/red (fumarprotocetraric acid); thallus brown with inconspicuous narrow, whitish pseudocyphellae that are slightly depressed, or dark brown to black and pseudocyphellae absent ..... B. fuscescens

5. Lichen substances absent; pseudocyphellae absent

B. simplicior

5. Lichen substances present, variable; pseudocyphellae present.

6. Cortex $\mathrm{C}+$ red (gyrophoric acid). B. friabilis

6. Cortex C7

7. Medulla and inner cortex PD+ red (fumarprotocetraric acid); outer cortex without lichen substances; pseudocyphellae ovoid B. trichodes ssp. trichodes 7. Medulla without lichen substances, or with same chemistry as cortex; cortex PD+ orange or yellow (salazinic or psoromic acids) or $\mathrm{KOH}+$ yellow (barbatolic acid); pseudocyphellae elongate-fusiform . 
8. Cortex $\mathrm{KOH}+$ yellow to red and $\mathrm{PD}+$ orange (salazinic acid - requires TLC, spots tests were unreliable for our specimen); medulla without lichen substances; thallus dark olivaceous, slightly twisted and curling.... B. salazinica (Fig. 2.4. A-B)

8. Cortex and medulla PD+ yellow; thallus not distinctly twisted and curling.....

9. Cortex and medulla $\mathrm{KOH}+$ yellow (barbatolic acid); thallus pale brown/tan ...... B. pikei 9. Cortex and medulla $\mathrm{KOH}$ - (psoromic acid - requires TLC, spots tests were unreliable for our specimen); thallus dark brown-olivaceous...... B. kockiana

\section{CETRARIA:}

1. Medulla PD+ red (fumarprotocetraric, lichesterinic, and protolichesterinic acids); lobes canaliculate with a pitted surface; pseudocyphellae laminal and marginal; apothecia not observed in Forillon material (they are uncommon in the $C$. islandica group and rare in ssp. crispiformis, according to Kärnefelt 1979)............Cetraria islandica ssp. crispiformis 2. Medulla PD- (lichesterinic acid); lobes canaliculate with a smooth surface; pseudocyphellae marginal, forming a more or less continuous line; apothecia concolorous with thallus, marginal on lobe tips. C. ericetorum ssp. ericetorum

\section{CLADONIA:}

1. Podetia without a cortex, appearing dull and webby; abundantly branched forming dense cushions over substrate

1. Podetia with a cortex, appearing smooth; abundantly branched or not; not typically forming dense cushions over substrate

2. Thallus greyish-white, $\mathrm{KC}-, \mathrm{PD}+$ red, $\mathrm{KOH}+$ yellow (fumarprotocetraric acid, atranorin); tips of podetia appearing swept to one side Cladonia rangiferina 2. Thallus yellowish-green, $\mathrm{KC}+$ yellow, $\mathrm{P}-, \mathrm{KOH}$ - (usnic acid)

3. UV-, containing rangiformic acid (requires TLC to confirm); thallus with a central branch or trunk, forming mats without hemispherical mounds C. mitis 3. UV+ blue-white (perlatolic acid); thallus without a central branch, forming distinct hemispherical mounds C. stellaris

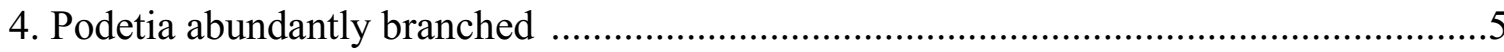

4. Podetia not branched or sparsely branched.......................................................

5. Thallus greenish-grey, KC- $\mathrm{PD}+$ red (fumarprotocetraric acid only); esorediate C. furcata

5. Thallus yellowish-green, $\mathrm{KC}+$ yellow, $\mathrm{PD}$ - (usnic acid only).....

6. Podetia finely branched (ca. $2 \mathrm{~mm}$ wide) with pointed, thorn-like tips.... C. uncialis ssp. uncialis

6. Podetia thickly branched (ca. $4 \mathrm{~mm}$ wide) with many perforations at tips

C. labradorica (Fig. 2.4. C-D) 


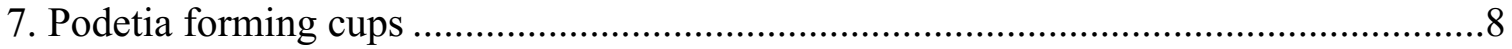

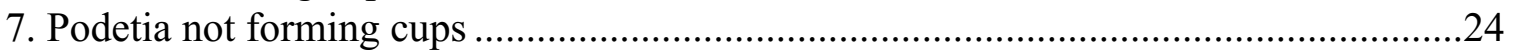

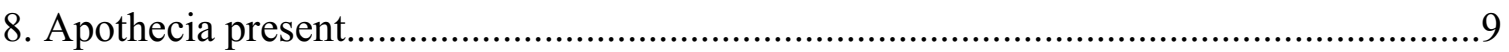

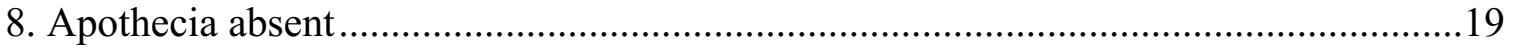

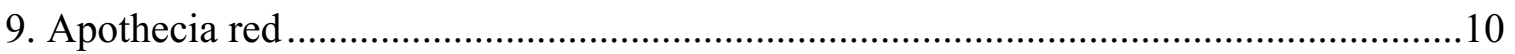

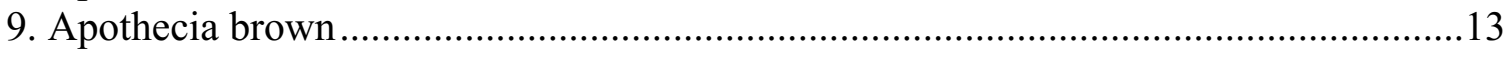

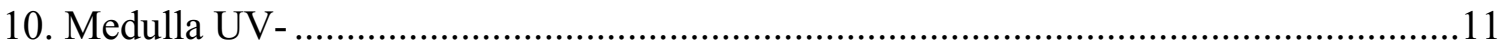

10. Medulla UV+ blue-white (squamatic acid) ........................................... C. sulphurina

11. Thallus esorediate; without zeorin (negative in spot tests - TLC required to confirm); apothecia proliferating from margins of irregular, indistinct open cups (look like open

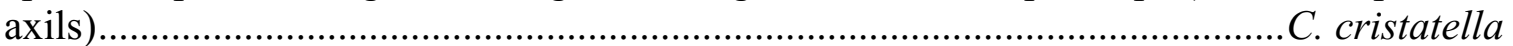

11. Thallus sorediate; with zeorin (negative in spot tests - TLC required to confirm) .....12

12. Soredia granular; cups with even margins C. pleurota

12. Soredia farinose; cups with irregular margins C. deformis

13. Thallus UV+ blue-white (squamatic acid) or whitish (homosekkaic acid) .14

13. Thallus UV-

14. Thallus $\mathrm{PD}+$ red, $\mathrm{UV}+$ whitish (fumarprotocetraric, typically trace amounts, and homosekkaic acids - requires TLC to confirm); podetia not branched or heavily perforated C. rei

14. Thallus PD-, UV+ bright blue-white (squamatic acid only); podetia branching 2-3 times and heavily perforated at branch junctions C. crispata ssp. crispata

15. Cups with distinct corticate, plate-like squamules inside C. pyxidata

15. Cups sorediate or not, but never with corticate squamules inside .16

16. Podetia esorediate; apothecia proliferating from cup margins C. gracilis ssp. turbinata 16. Podetia sorediate .17

17. Thallus greenish, PD+ red (fumarprotocetraric acid only - requires TLC to confirm); podetia, including cups, with granular soredia; apothecia marginal on cups

C. chlorophaea

17. Thallus brownish, with other chemistry, without fumarprotocetraric acid; podetia, including cups, with granular soredia; apothecia marginal on cups .18

18. Thallus with cryptochlorophaeic acid (requires TLC to confirm) C. cryptochlorophaea 18. Thallus with merochlorophaeic acid (requires TLC to confirm) ... C. merochlorophaea

19. Podetia sorediate .20 
20. Thallus UV+ blue-white (squamatic acid) and PD-; cups open with margins curled inward C. cenotea 20. Thallus UV- and PD+ red (fumarprotocetraric acid); cups closed, margins not curled inward C. ochrochlora

21. Thallus $\mathrm{KOH}+$ yellow and $\mathrm{PD}+$ red (atranorin and fumarprotocetraric acid); cups closed, but podetia perforated C. ecmocyna ssp. ecmocyna 21.Thallus $\mathrm{KOH}-, \mathrm{PD}+$ red (fumarprotocetraric only); cups open or close. .22

22. Cups singular, without proliferations; podetia with abundant squamules C. phyllophora

22. Cups with proliferations; podetial squamules absent or sparse .23

23. Cups with apothecia proliferating from the margins; cups heavily perforated (looks like a sieve) C. multiformis 23. Cups with cups proliferating from centres of cups (in tiers like a cake); cups not perforated C. verticillata

25. Podetia UV-; esorediate C. cristatella

25. Podetia UV+ blue or white; sorediate or not .26

26. Podetia sorediate; thallus UV+ white (barbatic acid, UV reaction sometimes hard to see - TLC required to confirm) .C. macilenta var. bacillaris 26. Podetia esorediate, with abundant squamules covering entire stalk; thallus UV+ bluewhite (squamatic acid) C. bellidiflora

27. Thallus UV+ blue-white (squamatic acid); esorediate; podetia heavily squamulose 27. Thallus UV-; sorediate or not; podetial squamulose or not C. squamosa

28. Sorediate or with corticate granules .29

28. Esorediate. 33

29. Podetia with corticate granules; podetia $\mathrm{KOH}+$ yellow, $\mathrm{PD}$ - (atranorin, \pm traces of norstictic acid). C. acuminata 29. Podetia sorediate; podetia $\mathrm{KOH} \pm, \mathrm{PD}+$ red (fumarprotocetraric acid)

30. Soredia granular, terminal on podetial tips; podetia squamulose C. scabriuscula 30. Soredia more widespread; podetia not squamulose 
32. Farinose soredia covering entire stalk

C. coniocrea

32. Fine soredia patchy on upper half of stalks C. cornuta ssp. cornuta

33. Thallus $\mathrm{KOH}+$ yellow, $\mathrm{PD}+$ red (atranorin and fumarprotocetraric acid; TLC may be required to confirm atranorin as it can be in low quantities and the spot test is often hard to see); podetia robust, with abundant green leafy squamules C. turgida 33. Thallus $\mathrm{KOH}-, \mathrm{PD}+$ red (fumarprotocetraric acid only); podetia slender and without leafy squamules

34. Podetia greenish, smooth; stalks 6-7 cm tall and robust (ca. $2 \mathrm{~mm}$ ) C. maxima 34. Podetia brownish, smooth; stalks $4-5 \mathrm{~cm}$ tall and narrow $(\leq 1 \mathrm{~mm})$

C. gracilis ssp. gracilis

\section{COLLEMA \& LATHAGRIUM:}

1. Corticolous 2

1. Terricolous, bryicolous, or saxicolous; typically, calcareous habit

2. Isidiate; apothecia unknown

2. Non-isidiate; apothecia abundant, burgundy; cells of proper exciple more or less rectangular and stacked like a brick wall (subparaplectenchymatous) (Fig. A.4.1. B) Collema nigrescens

3. Isidia mostly cylindrical; thallus wrinkled and blistered C. furfuraceum

3. Isidia globular; thallus more or less smooth C. subflaccidum

4. Isidia laminal and marginal; lobes more or less pustulate; if fruiting, ascospores submuriform with a longitudinal septum and 3 transverse septa (Hinds \& Hinds 2007) Lathagrium fuscovirens 4. Isidia laminal only; lobes with more or less smooth margins; if fruiting, ascospores fusiform, 3-septate L. undulatum

\section{HYPOGYMNIA:}

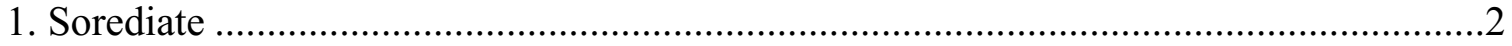

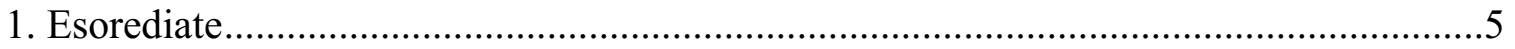

2. Soralia labriform (lip-shaped), on perforate lobe tips; medulla $\mathrm{PD} \pm$..........................

2. Soralia not lip-shaped; medulla PD-.................................................................. 4

3. Medulla PD + red/orange (physodalic and protocetraric acids); medullary ceiling white Hypogymnia physodes

3. Medulla PD-; medullary ceiling dark brown-black H. vittata 
4. Thallus mineral grey; lobes tube-like, erect or draping, ca. 1-2 mm wide, tips not perforated; soralia on the upper surface of lobe tips.... H. tubulosa 4. Thallus brown or with brown patches; lobes appressed or semi-erect, if appressed then 1.5-2 mm wide, if semi-erect then finer (0.5-1 mm wide), tips \pm perforated; soredia at lobe tips, sparse. H. bitteri

5. Medulla PD-; thallus brown or with brown patches H. subobscura (Fig. 2.4. E-F)

5. Medulla PD + red/orange (physodalic and protocetraric acids); thallus mineral grey H. physodes

\section{LEPTOGIUM \& SCYTINIUM:}

1. Isidiate 2

1. Without true isidia. 3

2. Tomentum on lower surface absent; isidia cylindrical Leptogium cyanescens

2. Tomentum on lower surface present, whitish; isidia granular L. acadiense

3. Thallus foliose, slate-grey and broad (2-3 cm across), forming a dense cushion; upper surface of lobes distinctly wrinkled; lobe margins with abundant, delicate isidia-like growths proliferating.... S. lichenoides 3. Thallus squamulose, brownish-charcoal; squamules smooth, but ultimately obscured by abundant coralloid extensions that superficially resemble isidia.....

4. Apothecia abundant, lecanorine with a burgundy disk; ascospores muriform (3 longitudinal septa and 5 transverse septa) and ca. 21 x $14 \mu \mathrm{m}$ S. tenuissimum 4. Apothecia absent S. teretiusculum (Fig. 2.6. A-B)

\section{LOBARIA:}

1. Primary photobiont green algae; with cephalodia 2

1. Primary photobiont cyanobacteria (thallus yellowish-grey when dry/bluish when wet); soralia bluish-grey. Lobaria scrobiculata

2. Thallus sorediate and isidiate along margins and reticulate ridges; medulla PD+ orange (norstictic and \pm stictic acid), C-; apothecia present or absent, marginal and along reticulate ridges; cephalodia on lower surface L. pulmonaria 2. Soredia and isidia absent; medulla PD-, C+ red (flash) (gyrophoric acid); thallus appearing slightly wrinkled, but without reticulate ridges; apothecia abundant, laminal; cephalodia internal, visible as bumps on the lower surface. L. quercizans

\section{MELANELIXIA \& MELANOHALEA:}

1. Sorediate, isidiate or both 2

1. Vegetative propagules absent 4 
2. Medulla C- (without lichen substances); isidia clavate to spatulate (hollow and inflated)..... Melanohalea exasperatula

2. Medulla $\mathrm{C}+$ red (lecanoric acid); isidia cylindrical, solid 3

3. Thallus appears abraded where isidia have rubbed away and laminal soralia form; isidia up to $0.15 \mathrm{~mm}$, typically not branching Melanelixia subaurifera 3. Esorediate; isidia long (up to $0.24 \mathrm{~mm}$ ) and often branching. M. glabratula

4. Medulla KOH-, PD- (without lichen substances); upper surface of lobes with cylindrical papillae topped with white pseudocyphellae

4. Medulla $\mathrm{KOH} \pm, \mathrm{PD}+$ Melanohalea exasperata (Fig. 2.5. A-B)

5. Medulla $\mathrm{PD}+$ orange, $\mathrm{KOH}+$ yellow to red (norstictic acid). M. trabeculata

5. Medulla $\mathrm{PD}+$ red, $\mathrm{KOH}$ - (fumarprotocetraric acid) 6

6. Pseudocyphellae laminal; ascospores ca. $14 \mu \mathrm{m}$ long M. olivacea

6. Pseudocyphellae absent; ascospores ca. $11 \mu \mathrm{m}$ long M. septentrionalis

\section{NEPHROMA:}

1. Soredia abundant granular soredia marginally and laminally Nephroma parile

1. Esorediate.

2. Medulla pale yellow, $\mathrm{KOH}+$ red-purple (nephromin), $\mathrm{PD}+$ dull orange spot (unknown substance), C-, UV-; thallus abundantly lobulate; bryicolous (known to be corticolous elsewhere according to Wetmore (1960), Brodo et al. (2001), and Hinds \& Hinds (2007)) N. laevigatum 2. Medulla white, $\mathrm{KOH}+$ yellow, $\mathrm{PD}+$ bright yellow, and $\mathrm{UV}+$ blue-white and yellow in some areas (zeorin, nephrin and 1-2 unknown substances); corticolous N. bellum

\section{PANNARIA \& PROTOPANNARIA:}

1. Thallus foliose, grey-brown with a bluish hypothallus; medulla PD+ orange-red (pannarin); ascospores simple, colourless and ca. $16.6 \mu \mathrm{m}$ long ......... Pannaria rubiginosa 1. Thallus squamulose, grey-brown; medulla without lichen substances; ascospores simple, colourless, ca. $23 \mu \mathrm{m}$ long and heavily ornamented (visible at 400X magnification) Protopannaria pezizoides

\section{PARMELIA:}

1. Esorediate and non-isidiate; rhizines squarrose (must look at central rhizines as young rhizines at lobe margins often appear simple) P. fertilis (Fig. 2.5. E-F) 1. Isidiate or sorediate; rhizines squarrose or not 
3. Squarrose rhizines (must look at central rhizines as young rhizines at lobe margins often appear simple); corticolous P. squarrosa 3. Simple to furcate rhizines, never squarrose (must look at central rhizines as young rhizines at lobe margins often appear simple); lignicolous on exposed roots, however more typically saxicolous (Brodo et al 2001; Hinds \& Hinds 2007) P. saxatilis

\section{PARMELIOPSIS:}

1. Thallus mineral grey Parmeliopsis hyperopta

1. Thallus yellowish-green (usnic acid) 2

2. Soredia mostly laminal, in irregular patches.... P. ambigua

2. Soredia mostly capitate on lobe tips P. capitata

\section{PELTIGERA:}

1. Primary photobiont green algae; cephalodia present 2

1. Primary photobiont cyanobacteria; cephalodia absent 3

2. Apothecia, if present, red-brown disks with a continuous cortex on the lower surface; lobe margins wavy; lower surface of thallus black in the centre and white at margins; veins typically indistinct.... Peltigera aphthosa 2. Apothecia were not observed in Forillon material; however, the patchy lower cortex of this species' red-brown apothecia is a strong character for differentiating it from $P$. aphthosa (Brodo et al. 2001). In the absence of apothecia, the conspicuously crisped lobe margins and pale lower surface of thallus, which is more distinctly veined throughout than in $P$. aphthosa, can be diagnostic. P. leucophlebia

3. Soralia laminal, $\mathrm{KC}+$ red (gyrophoric and methylgyrophoric acid); rhizines tufted, never simple Peltigera extenuata

3. Esorediate; rhizines various

4. Veins absent on lower surface which is smooth and cream-coloured at margins; thallus dark green when wet; lobes are thick, appearing spongy .P. malacea 4. Veins distinct or clear pattern of dark and light spots (interspaces) on lower surface; thallus blue, brown or black when wet; lobes not appearing spongy

5. Lower surface brown to black (except at margins) with pattern of small, white depressions (interspaces)

6. Thallus with abundant regeneration lobules along margins and cracks; rhizines fasciculate, arranged in concentric rings (though often sparsely); upper surface glabrous; apothecia unknown P. elizabethae 
6. Thallus without regeneration lobules; rhizines fasciculate, arranged in concentric rows which typically correspond to rows of depressions on the upper surface; apothecia round, brown-red and flat. P. horizontalis

7. Veins white to pale throughout, conspicuously raised and tomentose; rhizines white, long (ca. $10 \mathrm{~mm}$ ) and simple with squarrose branches at tips; thallus thin and papery

P. membranacea

7. Veins brown to black (centrally), if pale or white then not tomentose; rhizines and thallus not as above

8. Thallus glabrous.

8. Thallus tomentose

9. Thallus with regeneration lobules or phyllidia; veins brownish, smooth; rhizines simple and smooth, pale to brownish centrally P. praetextata 9. Thallus without regeneration lobules; veins dark or almost white; rhizines simple or brushy, pale or dark.

10. Lobes large, ca. 2-3 cm wide; veins dark brown to black and flattish; rhizines dark, slender and brushy ............................................................................ neopolydactyla 10. Lobes $<2 \mathrm{~cm}$ wide; veins raised, narrow and white at margins, turning pale-brown towards centre; rhizines pale and simple P. degenii

11. Thallus with regeneration lobules or phyllidia; veins brownish, smooth; rhizines simple and smooth, pale to brownish centrally..... P. praetextata 11. Thallus without regeneration lobules; veins pale or dark; rhizines not simple throughout

12. Veins pale, smooth; rhizines slender at margins, becoming bushy and confluent toward centre; thallus light grey, dull, margins downturned; tomentum variable. $P$. canina 12. Veins dark brown; rhizines short and bristly, forming dense mat beneath thallus; thallus light grey and sometimes brownish, margins upturned; heavily tomentose throughout P. rufescens

\section{PHAEOPHYSCIA:}

1. Esorediate; thallus dark brown to grey; saxicolous Phaeophyscia decolor

1. Sorediate

2. Medulla orange, $\mathrm{KOH}+$ purple (skyrin) P. rubropulchra

2. Medulla white, $\mathrm{KOH}-$

3. Soredia mostly marginal, if at lobe tips then never capitate ........................................

3. Soredia distinctly capitate at lobe tips or exclusively laminal .......................................6

4. Soredia greenish, with pale/colourless cortical hairs arising from marginal soralia 
5. Thallus greenish to brownish; lobes ca. 1-1.5 mm wide; soredia coarsely granular, greenish to almost black, mostly marginal and sometimes laminal; substrates various

5. Thallus dark, charcoal to black; lobes ca. $0.5 \mathrm{~mm}$ (always $<1 \mathrm{~mm}$ ) wide; soredia coarsely granular (appearing isidioid), black and marginal; saxicolous on calcareous rocks. P. sciastra

6. Soredia laminal, orbicular; rhizines inconspicuous P. orbicularis 6. Soredia capitate on lobe tips; rhizines abundant and protruding from the lobe and/or apothecia margins like whiskers

7. Thallus brownish, lobes 1-2 mm wide and concave; rhizines abundant, black and clearly seen protruding from underside like whiskers; apothecia absent P. hispidula 7. Lobes 0.5-1 mm wide, convex or flat but not concave; apothecia abundant (uncharacteristic), lecanorine and rimmed with rhizines; ascospores brown, 1-septate and ca. $25 \mu \mathrm{m}$ long. P. pusilloides

\section{PHYSCIA:}

1. Sorediate 2

1. Esorediate.

2. Lobes without marginal cilia; soredia marginal and granular Physcia millegrana

2. Lobes with white marginal cilia; soredia on lobe tips

3. Soredia greenish, inside helmet-shaped lobe tips; corticolous or lignicolous

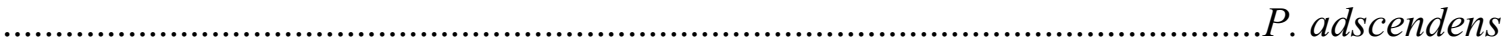

3. Soralia labriform at lobe tips; saxicolous on calcareous rocks P. tenella

4. Medulla $\mathrm{KOH}+$ yellow (atranorin and zeorin); apothecia abundant and occurring centrally and close to lobe tips ( $<2 \mathrm{~mm}$ from tips)... P. alnophila 4. Medulla $\mathrm{KOH}$ - (without lichen substances); apothecia abundant and centrally laminal P. stellaris

\section{RAMALINA:}

1. Branches not hollow or perforated; soralia discrete, round-oval with farinose soredia Ramalina farinacea

1. Branches hollow and perforated; sorediate or not

2. Sorediate (granular at tips of branches); apothecia uncommon R. roesleri

2. Esorediate; apothecia common R. dilacerata 


\section{STEREOCAULON:}

1. Primary thallus persistent, crustose...................................... Stereocaulon condensatum

1. Primary thallus not persistent.

2. Phyllocladia PD-; pinkish tomentum; cephalodia dark and bristly

S. pashale

2. Phyllocladia PD+ orange (long reaction, 60 seconds or more - atranorin, stictic acid and \pm norstictic acid); thick, whitish, arachnoid tomentum; cephalodia absent in Forillon material, however, typically has cephalodia immersed in tomentum (Hinds \& Hinds 2007)

S. tomentosum

\section{TUCKERMANOPSIS:}

1. Medulla $\mathrm{C}+$ pink/red (olivetoric acid) Tuckermanopsis ciliaris

1. Medulla C2

2. Medulla UV+ blue (alectoronic acid) T. americana

2. Medulla UV3

3. Apothecia laminal; thallus without lichen substances (confirm with TLC); corticolous (Fig. A.5.1). Tuckermanopsis sp. 1

3. Apothecia marginal; thallus with protolichesterinic acid (negative in spot tests)

4. Thallus with pycnidia projecting from lobe margins; apothecia sparse T. orbata

4. Thallus without pycnidia projecting from lobe margins; apothecia abundant and crowding entire thallus T. sepincola

\section{USNEA:}

1. Medulla $\mathrm{KOH}-, \mathrm{UV}+$ white (squamatic acid); thallus tufted Usnea subfloridana

1. Medulla $\mathrm{KOH} \pm$ yellow to blood red, UV-; thallus tufted or pendant

2. Thallus KOH- (without salazinic acid); long (ca. $30 \mathrm{~cm}$ ) and pendant with cortex disintegrating on main branches (almost ecorticate in some sections)..... Usnea longissima 2. Thallus $\mathrm{KOH}+$ yellow to blood red (salazinic acid); pendant or not; cortex intact..........3

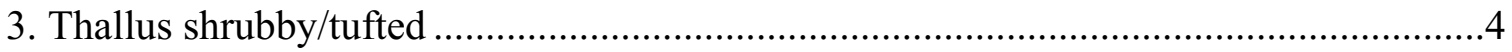

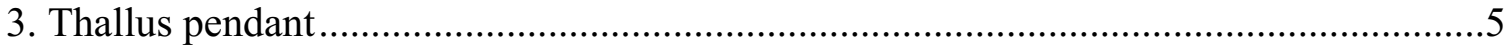

4. Soralia tuberculate with granular soredia (as in U. substerilis) to excavate with more or less granular soredia, if excavate then with cortical 'flaps' as described by Goward (1999) (as in U. lapponica). U. sp. 1 4. Soralia punctiform, never with cortical 'flaps' $U$. diplotypus

5. Fibrils in a fishbone pattern U. dasypoga 
5. Fibrils in a random pattern.

6. Medulla thin (ca. 12\%) and axis comparably thick (ca. 50\%); base distinctly

blackened, reaching up to the main branches (ca. $10 \mathrm{~mm})$................................. silesiaca 6. Medulla (ca. $27 \%$ ) and axis (30\%) medium thickness; base not distinctly blackened U. scabrata

\section{XANTHORIA \& XANTHOMENDOZA:}

1. Sorediate; apothecia absent; saxicolous Xanthoria sorediata

1. Esorediate; apothecia common; corticolous or saxicolous .2

2. Saxicolous on calcareous rocks, typically in maritime habitats; lobes convex and thick, appressed to substrate X. elegans

2. Corticolous; maritime habit or not; lobes thick or thin

3. Attached by rhizines Xanthomendoza hasseana

3. Attached by hapters.

4. Thallus with flat, thin lobes Xanthoria parietina

4. Thallus with semi-erect lobes, forming cushions X. polycarpa 


\section{A.4 Subparaplectenchymatous cells in the proper exciple of Collema nigrescens}

Collema nigrescens has subparaplectenchymatous cells in its proper exciple, which are long and rectangular, appearing stacked like a brick wall (Fig. A.4.1. B). Cell shape in the proper exciple is an important diagnostic feature in separating this species from the rare, and otherwise morphologically indistinct C. pulchellum var. pulchellum, which was not found in Forillon during my study. The latter species has paraplectenchymatous cells, which are rounder and more or less equal in width and length (Fig. A.4.1. A). Figure A.4.1, below, illustrates this difference.

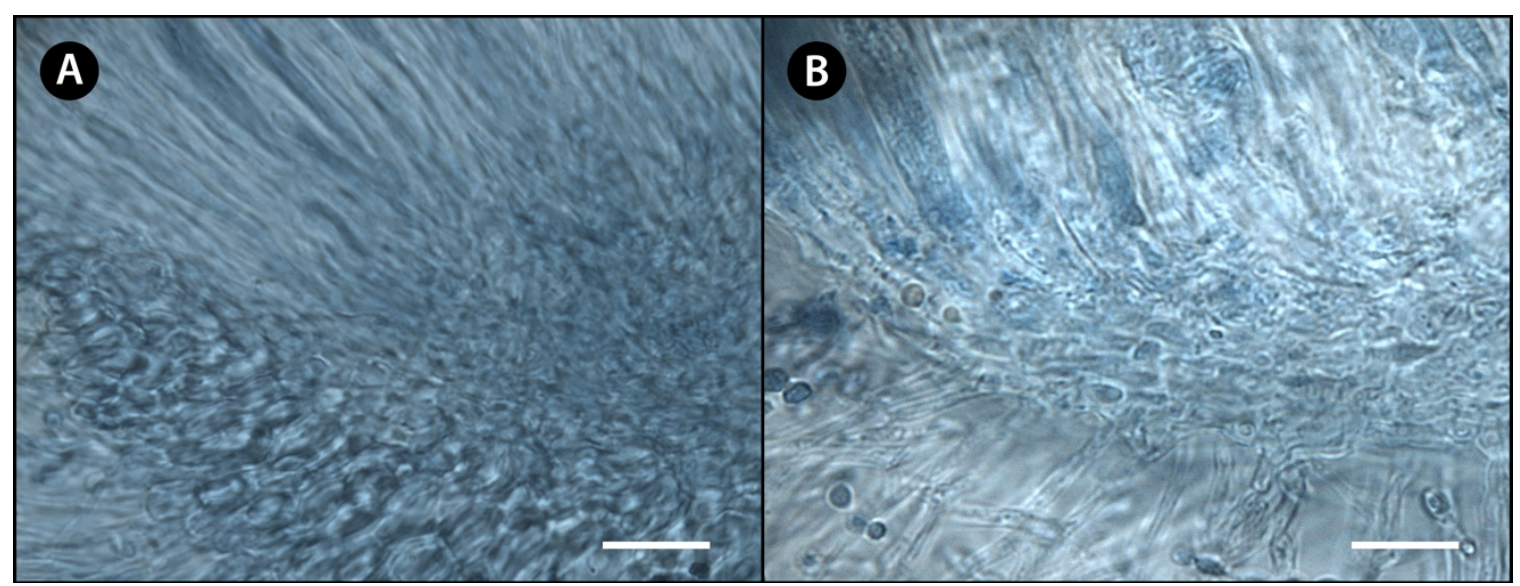

Figure A.4.1. The difference in cell shape in the proper exciple of two Collema species. A, Collema pulchellum var. pulchellum (from Macoun, collection CANL 2426, CANL). B, Collema nigrescens (from H.A. Paquette 71, CANL). 


\section{A.5 Laminal apothecia of Tuckermanopsis sp. 1 (H.A. Paquette 635)}

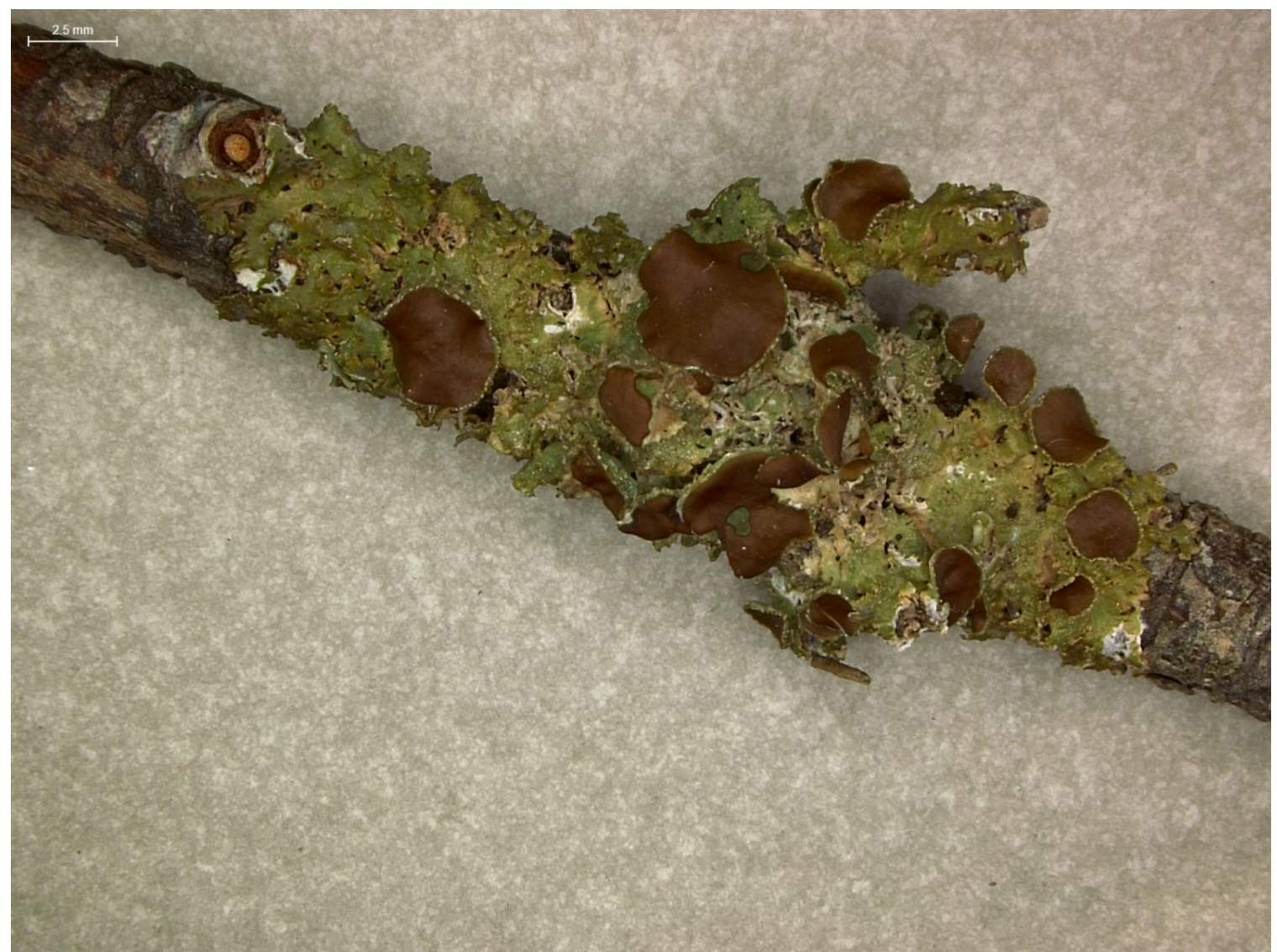

Figure A.5.1. Apothecia of specimen H.A. Paquette 635. The apothecia are laminal, and the specimen contains no lichen substances (confirmed with TLC) which is not congruent with any species presently described (Brodo et al. 2001, Esslinger 1973, Hinds \& Hinds 2007, Kärnfelt 1979), so it may represent a novel taxon. 


\section{Appendix B Supplementary items referenced in Chapter 3}

\section{B.1 Global Positioning System coordinates of calicioid collection sites in Forillon National Park}

Table B.1.1 Latitude and longitude for each calicioid collection by collection number, as given in Appendix B.2. Descriptions of location and habitat are given directly in the annotated checklist in Appendix B.3.

\begin{tabular}{|c|c|c|c|}
\hline Collection No. & Latitude & Longitude & Elevation (m) \\
\hline H. Paquette 39 & 48.81684 & -64.22777 & 81 \\
\hline H. Paquette 131 & 48.75173 & -64.16320 & 33 \\
\hline H. Paquette 138 & 48.95305 & -64.47142 & 159 \\
\hline H. Paquette 141 & 48.95305 & -64.47142 & 159 \\
\hline H. Paquette 142 & 48.95305 & -64.47142 & 159 \\
\hline H. Paquette 152 & 48.95305 & -64.47142 & 159 \\
\hline H. Paquette 165 & 48.84564 & -64.26653 & 47 \\
\hline H. Paquette 177 & 48.84412 & -64.26556 & 55 \\
\hline H. Paquette 180 & 48.84564 & -64.26653 & 47 \\
\hline H. Paquette 196 & 48.95188 & -64.47256 & 193 \\
\hline H. Paquette 199 & 48.94026 & -64.45791 & 304 \\
\hline H. Paquette 204 & 48.94026 & -64.45791 & 304 \\
\hline H. Paquette 210 & 48.93760 & -64.45670 & 310 \\
\hline H. Paquette 212 & 48.92808 & -64.46682 & 326 \\
\hline H. Paquette 234 & 48.94755 & -64.48005 & 264 \\
\hline H. Paquette 241 & 48.92808 & -64.46682 & 326 \\
\hline H. Paquette 260 & 48.94664 & -64.47930 & 289 \\
\hline H. Paquette 285 & 48.83483 & -64.26285 & 271 \\
\hline H. Paquette 286 & 48.83483 & -64.26285 & 271 \\
\hline H. Paquette 289 & 48.83483 & -64.26285 & 271 \\
\hline H. Paquette 290 & 48.83483 & -64.26285 & 271 \\
\hline H. Paquette 319 & 48.89024 & -64.40700 & 409 \\
\hline H. Paquette 320 & 48.89024 & -64.40700 & 409 \\
\hline H. Paquette 339 & 48.89024 & -64.40700 & 409 \\
\hline H. Paquette 341 & 48.87976 & -64.37770 & 157 \\
\hline H. Paquette 342 & 48.87976 & -64.37770 & 157 \\
\hline H. Paquette 343 & 48.87976 & -64.37770 & 157 \\
\hline H. Paquette 362 & 48.87976 & -64.37770 & 157 \\
\hline H. Paquette 378 & 48.90685 & -64.35088 & 23 \\
\hline H. Paquette 406 & 48.89250 & -64.40833 & 426 \\
\hline
\end{tabular}




\begin{tabular}{|c|c|c|c|}
\hline Collection No. & Latitude & Longitude & Elevation (m) \\
\hline H. Paquette 419 & 48.89250 & -64.40833 & 426 \\
\hline H. Paquette 420 & 48.89024 & -64.40700 & 409 \\
\hline H. Paquette 431 & 48.89984 & -64.41596 & 436 \\
\hline H. Paquette 447 & 48.94779 & -64.48051 & 260 \\
\hline H. Paquette 448 & 48.94779 & -64.48051 & 260 \\
\hline H. Paquette 460 & 48.94840 & -64.47872 & 217 \\
\hline H. Paquette 477 & 48.85913 & -64.37998 & 130 \\
\hline H. Paquette 482 & 48.85913 & -64.37998 & 130 \\
\hline H. Paquette 492 & 48.85913 & -64.37998 & 130 \\
\hline H. Paquette 493 & 48.85913 & -64.37998 & 130 \\
\hline H. Paquette 508 & 48.85913 & -64.37998 & 130 \\
\hline H. Paquette 517 & 48.89455 & -64.41261 & 411 \\
\hline H. Paquette 521 & 48.89455 & -64.41261 & 411 \\
\hline H. Paquette 522 & 48.89455 & -64.41261 & 411 \\
\hline H. Paquette 523 & 48.89455 & -64.41261 & 411 \\
\hline H. Paquette 525 & 48.90713 & -64.42038 & 459 \\
\hline H. Paquette 528 & 48.90713 & -64.42038 & 459 \\
\hline H. Paquette 578 & 48.81359 & -64.22518 & 99 \\
\hline H. Paquette 579 & 48.81359 & -64.22518 & 99 \\
\hline H. Paquette 587 & 48.85297 & -64.42340 & 8 \\
\hline H. Paquette 616 & 48.85917 & -64.33118 & 271 \\
\hline H. Paquette 620 & 48.87004 & -64.34996 & 365 \\
\hline H. Paquette 623 & 48.86930 & -64.34778 & 378 \\
\hline H. Paquette 650 & 48.84816 & -64.31974 & 211 \\
\hline H. Paquette 663 & 48.84030 & -64.28482 & 360 \\
\hline H. Paquette 684 & 48.85192 & -64.42878 & 3 \\
\hline H. Paquette 717 & 48.82883 & -64.26181 & 248 \\
\hline H. Paquette 720 & 48.82883 & -64.26181 & 248 \\
\hline H. Paquette 727 & 48.90 & -64.38 & - \\
\hline H. Paquette 731 & 48.92721 & -64.32104 & 15 \\
\hline H. Paquette 732 & 48.92721 & -64.32104 & 15 \\
\hline H. Paquette 738 & 48.92721 & -64.32104 & 15 \\
\hline H. Paquette 741 & 48.92721 & -64.32104 & 15 \\
\hline H. Paquette 799 & 48.88986 & -64.37150 & 102 \\
\hline H. Paquette 802 & 48.88055 & -64.34723 & 223 \\
\hline H. Paquette 893 & 48.85381 & -64.42583 & 9 \\
\hline H. Paquette 895 & 48.85381 & -64.42583 & 9 \\
\hline H. Paquette 896 & 48.94755 & -64.48005 & 264 \\
\hline
\end{tabular}




\begin{tabular}{|l|l|l|c|}
\hline \multicolumn{1}{|c|}{ Collection No. } & Latitude & Longitude & Elevation (m) \\
\hline H. Paquette 897 & 48.94755 & -64.48005 & 264 \\
\hline H. Paquette 898 & 48.94755 & -64.48005 & 264 \\
\hline H. Paquette 899 & 48.94755 & -64.48005 & 264 \\
\hline H. Paquette 900 & 48.94755 & -64.48005 & 264 \\
\hline H. Paquette 901 & 48.94755 & -64.48005 & 264 \\
\hline H. Paquette 291A & 48.83451 & -64.25617 & 361 \\
\hline H. Paquette 291B & 48.83451 & -64.25617 & 361 \\
\hline H. Paquette 418A & 48.89250 & -64.40833 & 426 \\
\hline H. Paquette 418B & 48.89250 & -64.40833 & 426 \\
\hline H. Paquette 449A & 48.94840 & -64.47872 & 217 \\
\hline H. Paquette 449B & 48.89250 & -64.40833 & 426 \\
\hline H. Paquette 467A & 48.94840 & -64.47872 & 217 \\
\hline H. Paquette 467B & 48.94840 & -64.47872 & 217 \\
\hline H. Paquette 524A & 48.89455 & -64.41261 & 411 \\
\hline H. Paquette 527A & 48.90713 & -64.42038 & 459 \\
\hline H. Paquette 527B & 48.90713 & -64.42038 & 459 \\
\hline H. Paquette 527C & 48.90713 & -64.42038 & 459 \\
\hline H. Paquette 535A & 48.91645 & -64.42843 & 494 \\
\hline H. Paquette 535B & 48.91645 & -64.42843 & 494 \\
\hline H. Paquette 716A & 48.82883 & -64.26181 & 248 \\
\hline H. Paquette 716B & 48.82883 & -64.26181 & 248 \\
\hline H. Paquette 716C & 48.82883 & -64.26181 & 248 \\
\hline
\end{tabular}




\section{B.2 Annotated checklist of calicioid lichen and fungi species of Forillon National Park}

The following list is organized alphabetically by genus and species. New records for Quebec are preceded by an asterisk (*). Non-lichenized species are preceded by a dagger $(\dagger)$. Nomenclature follows Esslinger (2018) and any divergences reflect the opinions of the authors. Taxonomic authorities follow Brummitt and Powell (1996). GPS coordinates for collections are given in Appendix B.1, Table B.1.1.

*Calicium denigratum (Vain.) Tibell

FIGURE 3.4A-D.

NOTE. - This species is reported here as new to Quebec. It is characterized by black, shiny (epruinose) stalks and bell-shaped capitula (Fig. 4A). The stalks are approximately 1-2 mm tall and the ascospores are approximately $11 \mu \mathrm{m}$ long, brown, ellipsoidal, 1-septate and pinched at the septum (Fig. 4B). The ascospores also have a coarsely cracked surface which consistently distinguishes this species from the morphologically similar Calicium abietinum, whose ascospores are "minutely warted" (McMullin et al. 2012). This feature of the ascospores can be viewed using a compound microscope with a $1000 \mathrm{X}$ lens, though it is best seen under scanning electron microscope (McMullin et al. 2012) (Fig. 4C). Calicium abietinum also has lenticular capitula, instead of bell-shaped capitula, and its stalks are 0.6-0.9 $\mathrm{mm}$ tall verses 0.7-1.3 $\mathrm{mm}$ tall (McMullin et al. 2012, Selva 2014). We found $C$. denigratum only once during our study, on the exposed wood of a mature Picea in an area dominated by large Picea with an understory of Alnus and Betula saplings with partial sun exposure; the groundcover was a mix of tall grass and ferns.

Specimen examined. - CANADA. QUEBEC. M.R.C. La Côte-de-Gaspé: Forillon National Park, Les Lacs Trail between first and second lake of the Lacs de Penouille, elev. 460 m, 4.ix.2018, lignicolous on mature Picea sp., H. Paquette 527A (CANL).

\section{Calicium glaucellum Ach.}

Specimens examined. - CANADA. QUEBEC. M.R.C. La Côte-de-Gaspé: Forillon National Park, N side of the road up Tower Mountain (E of QC-132), 26.viii.2018, lignicolous on conifer snag, H. Paquette 289 (CANL); along the road up Tower Mountain (E of QC-132), E of tower facing Cap Bon Ami and the Gulf of St. Lawrence, 26.viii.2018, lignicolous on snag, H. Paquette 291B (CANL); Les Lacs Trail near the backcountry camping shelter at the Lacs de Penouille, 1.ix.2018, lignicolous on standing snag, $H$. Paquette 419 (CANL); N side of road between Ch. du Portage and Forillon National Park Operations Centre, exposed Thuja occidentalis swamp, 3.ix.2018, lignicolous on snag, $H$. Paquette 508 (CANL); Les Lacs Trail N of third lake of the Lacs de Penouille (S of Lac 
au Renard), 4.ix.2018, lignicolous on Betula sp. snag, H. Paquette 535B (CANL); N side of Les Crêtes Trail (E of QC-132), mature Thuja occidentalis forest adjacent to wetland, 13.ix.2018, lignicolous on Thuja occidentalis snag, H. Paquette 716 A (CANL); Les Lacs Trail at $\mathrm{N}$ end of first lake of the Lacs de Penouille (location of backcountry camping shelter), 14.ix.2018, lignicolous on standing snag, H. Paquette 524A (CANL).

\section{Calicium salicinum Pers.}

Specimens examined. - CANADA. QUEBEC. M.R.C. La Côte-de-Gaspé: Forillon National Park, Les Lacs Trail near the backcountry camping shelter at the Lacs de Penouille, 2.ix.2018, lignicolous on Thuja occidentalis, H. Paquette 449B (CANL); N side of road between Ch. du Portage and Forillon National Park Operations Centre, exposed Thuja occidentalis swamp, 3.ix.2018, lignicolous on Thuja occidentaliss, H. Paquette 492 (CANL); Les Crêtes Trail (NW of QC-132) S of first lookout on SE section of trail, 10.ix.2018, lignicolous on snag, H. Paquette 663 (CANL); N side of Les Crêtes Trail (E of QC-132), mature Thuja occidentalis forest adjacent to wetland, 13.ix.2018, lignicolous on Thuja occidentalis snag, H. Paquette 716C (CANL).

Calicium trabinellum (Ach.) Ach.

Specimens examined. - CANADA. QUEBEC. M.R.C. La Côte-de-Gaspé: Forillon National Park, Les Lacs Trail between trailhead off QC-197 and the first lookout, 24.viii.2018, lignicolous on snag, H. Paquette 234 (CANL); N side of road up Tower Mountain (E of QC-132), 26.viii.2018, lignicolous on conifer snag and snag, H. Paquette 285 (CANL), H. Paquette 290 (CANL); along road up Tower Mountain (E of QC-132), E of tower facing Cap Bon Ami and the Gulf of St. Lawrence, 26.viii.2018, lignicolous on snag, H. Paquette 291A (CANL); Le Portage Trail midway between south sector trailhead and junction with La Vallee Trail, 28.viii.2018, lignicolous on conifer snag, H. Paquette 341 (CANL); E shore of second lake of the Lacs de Penouille ( $\mathrm{N}$ of first lake with backcountry camping shelter), 1.ix.2018, lignicolous on snag, H. Paquette 431 (CANL); Les Lacs Trail near the backcountry camping shelter at the Lacs de Penouille, 1.ix.2018, lignicolous on snag, H. Paquette 418A (CANL); Les Lacs Trail at N end of first lake of the Lacs de Penouille (location of backcountry camping shelter), 4.ix.2018, lignicolous on driftwood roots, H. Paquette 522 (CANL), H. Paquette 523 (CANL); Les Lacs Trail N of third lake of the Lacs de Penouille (S of Lac au Renard), 4.ix.2018, lignicolous on snag, $H$. Paquette 535A (CANL); N side of Les Crêtes Trail (E of QC-132), mature Thuja occidentalis forest adjacent to wetland, 13.ix.2018, lignicolous on Thuja occidentalis snag, H. Paquette $716 C$ (CANL).

Chaenotheca brunneola (Ach.) Müll. Arg.

Specimens examined. - CANADA. QUEBEC. M.R.C. La Côte-de-Gaspé: Forillon National Park, N side of road between Ch. du Portage and Forillon National Park Operations Centre, exposed Thuja occidentalis swamp, 3.ix.2018, lignicolous on Thuja occidentalis snag, H. Paquette 493 (CANL); La Vallee Trail, wet Thuja occidentalis stand near trailhead, 14.ix.2018, lignicolous on Thuja occidentalis snag, H. Paquette 731 (CANL).

Chaenotheca chrysocephala (Ach.) Th. Fr. 
Specimens examined. - CANADA. QUEBEC. M.R.C. La Côte-de-Gaspé: Forillon National Park, Les Lacs Trail between trailhead off QC-197 and the first lookout, 24.viii.2018, lignicolous on root snag, H. Paquette 899 (CANL); La Vallee Trail, wet Thuja occidentalis stand near trailhead, 14.ix.2018, lignicolous on Thuja occidentalis snag, $H$. Paquette 738 (CANL).

Chaenotheca furfuracea (L.) Tibell

Specimens examined. - CANADA. QUEBEC. M.R.C. La Côte-de-Gaspé: Forillon National Park, Les Lacs Trail, side trail to Lac au Renard, 23.viii.2018, lignicolous on decomposing exposed roots, H. Paquette 210 (CANL); Les Lacs Trail between trailhead off QC-197 and the first lookout, 2.ix.2018, lignicolous on decomposing exposed roots, $H$. Paquette 467A (CANL).

Chaenotheca gracilenta (Ach.) Mattsson \& Middelb.

Specimen examined. - CANADA. QUEBEC. M.R.C. La Côte-de-Gaspé: Forillon National Park, Les Lacs Trail between trailhead off QC-197 and the first lookout, 2.ix.2018, lignicolous on decomposing exposed roots, H. Paquette 467B (CANL).

Chaenotheca hispidula (Ach.) Zahlbr.

Specimen examined. - CANADA. QUEBEC. M.R.C. La Côte-de-Gaspé: Forillon National Park, S side of Les Crêtes Trail NW of QC-132, Acer and Betula dominant forest, 10.ix.2018, corticolous on large Acer saccharum, H. Paquette 650 (CANL).

Chaenotheca laevigata Nádv.

Specimen examined. - CANADA. QUEBEC. M.R.C. La Côte-de-Gaspé: Forillon National Park, N side of Les Crêtes Trail (E of QC-132), mature Thuja occidentalis forest adjacent to wetland, 13.ix.2018, corticolous on large Thuja occidentalis, H. Paquette 720 (CANL).

Chaenotheca stemonea (Ach.) Müll. Arg.

Specimen examined. - CANADA. QUEBEC. M.R.C. La Côte-de-Gaspé: Forillon National Park, prescribed burn zone E of Le Portage Trail, 16.ix.2018, corticolous on large Pinus sp. (in crevices of roots at base), H. Paquette 802 (CANL).

Chaenotheca trichialis (Ach.) Hellb.

NOTE. - This appears to be the first time this species has been reported growing on resin (e.g., McMullin et al. 2018, Selva 2014, Tibell 1999). Typically, it is corticolous or lignicolous on a variety of coniferous and deciduous tree species, though it has also been reported on Trichaptum abietinum, a coniferous bracket fungus (Selva 2014). The resinicolous specimens we collected are morphologically congruent with our lignicolous collections of the same species.

Specimens examined. - CANADA. QUEBEC. M.R.C. La Côte-de-Gaspé: Forillon National Park, Les Lacs Trail between trailhead off QC-197 and the first lookout, 24.viii.2018, lignicolous on snag, H. Paquette 896 (CANL), H. Paquette 898 (CANL), resinicolous on root snag, H. Paquette 897 (CANL); Les Lacs Trail between first and 
second lake of the Lacs de Penouille, 4.ix.2018, resinicolous on Picea sp. snag, H. Paquette $527 B$ (CANL); La Grande Cavee N of Le Portage Trail near prescribed burn zone, 16.ix.2018, resinicolous on Picea sp. snag, H. Paquette 799 (CANL).

\section{Chaenotheca xyloxena Nádv.}

Specimens examined. - CANADA. QUEBEC. M.R.C. La Côte-de-Gaspé: Forillon National Park, La Chute Trail, 22.viii.2018, lignicolous on snag, H. Paquette 180 (CANL); Les Lacs Trail between trailhead off QC-197 and the first lookout, 24.viii.2018, lignicolous on snag, H. Paquette 901 (CANL); Les Lacs Trail between first and second lake of the Lacs de Penouille, 2.ix.2018, lignicolous on Abies balsamea snag, H. Paquette 448 (CANL); Les Crêtes Trail NW of QC-132, along ridge between lookouts, 7.ix.2018, lignicolous on snag, H. Paquette 620 (CANL); N side of Les Crêtes Trail (E of QC-132), mature Thuja occidentalis forest adjacent to wetland, 13.ix.2018, lignicolous on Thuja occidentalis, H. Paquette 717 (CANL); La Vallee Trail, wet Thuja occidentalis stand near trailhead, 14.ix.2018, lignicolous on snag, H. Paquette 732 (CANL).

\section{†Chaenothecopsis debilis (Sm.) Tibell}

Specimens examined. - CANADA. QUEBEC. M.R.C. La Côte-de-Gaspé: Forillon National Park, Les Lacs Trail between trailhead at QC-197 and the first lookout, 21.viii.2018, corticolous on snag, H. Paquette 142 (CANL), H. Paquette 152 (CANL); La Chute Trail between trailhead and waterfall, 22.viii.2018, corticolous on Acer saccharum, H. Paquette 177 (CANL); Le Portage Trail midway between south sector trailhead and junction with La Vallee Trail, 28.viii.2018, lignicolous on Acer saccharum snag, $H$. Paquette 343 (CANL); Les Lacs Trail near the backcountry camping shelter at the Lacs de Penouille, 2.ix.2018, lignicolous on Thuja occidentalis, H. Paquette 449A (CANL).

\section{* Chaenothecopsis oregana Rikkinen}

FIGURE 3.3 A-D.

NOTE. - This species is reported here as new to eastern North America. It is characterized by black, shiny (epruinose), frequently branching stalks approximately 0.5 $\mathrm{mm}$ tall, with multiple capitula on each stalk (Fig. 3A). The ascospores are brown, nonseptate, ellipsoidal, approximately $4.5 \mu \mathrm{m}$ long (Fig. 3B), and have an even ornamentation of dimples that resemble those of a peanut shell as seen under the scanning electron microscope (Fig. 3C). The stalks are $\mathrm{KOH}^{+}$violet. This species was found only once during our study on the resin of a mature Abies balsamea in a shaded forest dominated by mature A. balsamea, Betula, and Picea; the groundcover was primarily conifer needles and bryophytes with young trees of the same species in the understory.

Specimen examined. - CANADA. QUEBEC. M.R.C. La Côte-de-Gaspé: Forillon National Park, Les Lacs Trail (between Le Portage Trail and QC-197), elev. 409 m, 1.ix.2018, resinicolous on a mature Abies balsamea, H. Paquette 420 (CANL).

†Chaenothecopsis pusilla (Ach.) A.F.W. Schmidt

Specimen examined. - CANADA. QUEBEC. M.R.C. La Côte-de-Gaspé: Forillon National Park, Les Lacs Trail between third lookout and junction with the side trail to Lac au Renard, 23.viii.2018, lignicolous on Picea sp., H. Paquette 204 (CANL). 
†Chaenothecopsis pusiola (Ach.) Vain.

Specimens examined. - CANADA. QUEBEC. M.R.C. La Côte-de-Gaspé: Forillon National Park, La Chute Trail, 22.viii.2018, lignicolous on snag, H. Paquette 165 (CANL); Les Lacs Trail between trailhead off QC-197 and the first lookout, 24.viii.2018, lignicolous on snag, H. Paquette 900 (CANL); Les Lacs Trail between first and second lake of the Lacs de Penouille, 4.ix.2018, lignicolous on Picea sp. over Chaenotheca trichialis, $H$. Paquette 527C (CANL).

Cyphelium tigillare (Ach.) Ach.

Specimen examined. - CANADA. QUEBEC. M.R.C. La Côte-de-Gaspé: Forillon National Park, Les Lacs Trail at N end of first lake of the Lacs de Penouille (location of backcountry camping shelter), 4.ix.2018, lignicolous on driftwood roots, H. Paquette 517 (CANL).

†Mycocalicium subtile (Pers.) Szatala

Specimens examined. - CANADA. QUEBEC. M.R.C. La Côte-de-Gaspé: Forillon National Park, alongside trail to Land's End lookout from Cap-Gaspé, 20.viii.2018, lignicolous on snag, H. Paquette 131 (CANL); Les Lacs Trail between trailhead at QC197 and the first lookout, 21.viii.2018, lignicolous on snag, H. Paquette 141 (CANL); Les Lacs Trail between trailhead at QC-197 and the first lookout, 23.viii.2018, lignicolous on conifer snag, H. Paquette 196 (CANL); Les Lacs Trail where it crosses Beaudry Creek, 24.viii.2018, lignicolous on Abies balsamea, H. Paquette 241 (CANL); N side of road up Tower Mountain (E of QC-132), 26.viii.2018, lignicolous, H. Paquette 286 (CANL); Les Lacs Trail at $\mathrm{S}$ end of first lake of the Lacs de Penouille (location of backcountry camping shelter), 27.viii.2018, lignicolous on snag, H. Paquette 339 (CANL); Le Portage Trail midway between south sector trailhead and junction with La Vallee Trail, 28.viii.2018, lignicolous on conifer snag, H. Paquette 342 (CANL); Les Lacs Trail near the backcountry camping shelter at the Lacs de Penouille, 1.ix.2018, lignicolous on snag, H. Paquette 418B (CANL); $\mathrm{N}$ side of road between $\mathrm{Ch}$. du Portage and Forillon National Park Operations Centre, exposed Thuja occidentalis swamp, 3.ix.2018, lignicolous on Thuja occidentalis snag, H. Paquette 482 (CANL); Les Lacs Trail at $\mathrm{N}$ end of first lake of the Lacs de Penouille (location of backcountry camping shelter), 4.ix.2018, lignicolous on driftwood roots, H. Paquette 521 (CANL).

†Phaeocalicium betulinum (Nyl.) Tibell

Specimens examined. - CANADA. QUEBEC. M.R.C. La Côte-de-Gaspé: Forillon National Park, Mont Saint Alban cliffs, ca. $100 \mathrm{~m} \mathrm{~W}$ (upslope) of overflow parking at Cap Bon Ami Campground, 5.ix.2018, corticolous on Betula sp. twigs, H. Paquette 578 (CANL), H. Paquette 579 (CANL).

†Phaeocalicium compressulum (Nyl. ex Vain.) A.F.W. Schmidt

Specimens examined. - CANADA. QUEBEC. M.R.C. La Côte-de-Gaspé: Forillon National Park, $\mathrm{N}$ of campsite on Les Lacs Trail between first and second lakes of the Lacs de Penouille, 4.ix.2018, corticolous on Alnus viridis spp. crispa, H. Paquette 525 (CANL); La Taïga Trail, N side of sandspit, 23.ix.2018, corticolous on Alnus viridis spp. crispa 
twigs, H. Paquette 895 (CANL).

†Phaeocalicium flabelliforme Tibell

Specimen examined. - CANADA. QUEBEC. M.R.C. La Côte-de-Gaspé: Forillon National Park, La Taïga Trail, N side of sandspit, 23.ix.2018, corticolous on Betula sp. twigs, H. Paquette 893 (CANL).

†Phaeocalicium matthewsianum Selva \& Tibell

Specimens examined. - CANADA. QUEBEC. M.R.C. La Côte-de-Gaspé: Forillon National Park, $\mathrm{N}$ of campsite on Les Lacs Trail between first and second lakes of the Lacs de Penouille, 4.ix.2018, corticolous on smooth bark of young Betula sp., H. Paquette 528 (CANL); Les Crêtes Trail NW of QC-132, along ridge between lookouts, 7.ix.2018, corticolous on smooth bark of Betula sp. twigs, H. Paquette 623 (CANL).

†Phaeocalicium populneum (Brond. ex Duby) A.F.W. Schmidt

Specimens examined. - CANADA. QUEBEC. M.R.C. La Côte-de-Gaspé: Forillon National Park, English Creek, upstream from the bridge crossing on Le Portage Trail, 28.viii.2018, corticolous on Populus sp. twigs, H. Paquette 378 (CANL); Les Crêtes Trail NW of QC-132, along ridge between lookouts, 7.ix.2018, corticolous on Populus sp. twigs, H. Paquette 616 (CANL); La Taïga Trail on S side of road, 12.ix.2018, corticolous on Populus balsamifera twigs, H. Paquette 684 (CANL).

*Sclerophora coniophaea (Norman) Mattsson \& Middelb.

FIGURE 3.5 A-D.

NOTE. - This species is reported here as new to Quebec. The stalks are approximately $1 \mathrm{~mm}$ tall and covered in thick, orange-rust coloured pruina, giving them a shaggy appearance (Fig. 5A). The excipula do not form collars around the stalks, the photobiont is Trentepohlia, and the ascospores are non-septate, spherical, hyaline, and approximately $5.5 \mu \mathrm{m}$ in diameter (Fig. 5B). This species was found only once during our study, in a shaded, wet forest with a northeast aspect, dominated by Abies balsamea and Betula. The groundcover was moss with Acer spicatum saplings infilling. It was growing close to the ground on the bare wood of an Abies balsamea snag, sheltered by peeling bark.

Specimen examined. - CANADA. QUEBEC. M.R.C. La Côte-de-Gaspé: Forillon National Park, Les Lacs Trail between trailhead off QC-197 and the first lookout, elev. 260 m, 2.ix.2018, lignicolous on Abies balsamea snag under peeling bark within $1 \mathrm{~m}$ of ground, H. Paquette 447 (CANL).

Sclerophora peronella (Ach.) Tibell

FIGURE 3.6 A-D.

NOTE. - This taxon is listed as a species at risk under Schedule 1 of the Canadian Species at Risk Act (Government of Canada 2019). It is characterized by apothecia with reddish-brown, smooth stalks, approximately $1 \mathrm{~mm}$ tall and a pale pink mazaedium, covered in white pruina (Fig. 6A). The excipula do not form collars around the stalks, the photobiont is Trentepohlia, and the ascospores are non-septate, spherical, hyaline and 
approximately $3 \mu \mathrm{m}$ in diameter (Fig. 6B). It was found only once during our study growing on the exposed heartwood inside a large hollow of a mature Acer sp. in a partly shaded forest with a slight southwest aspect, dominated by mature Acer saccharum, Betula papyrifera and $B$. alleghaniensis, with an understory of a few small Abies balsamea and groundcover of ferns, bunch berries, moss, and small saplings. Due to its risk status, exact location data is not provided here.

Specimen examined. - CANADA. QUEBEC. M.R.C. La Côte-de-Gaspé: Forillon National Park, 13.ix.2018, lignicolous on the exposed heartwood inside of a large hollow of a mature Acer sp., H. Paquette 727 (CANL).

†Sphinctrina turbinata (Pers.) De Not.

Specimens examined. - CANADA. QUEBEC. M.R.C. La Côte-de-Gaspé: Forillon National Park, Les Lacs Trail between trailhead off QC-197 and the first lookout, 24.viii.2018, lichenicolous on Pertusaria sp., H. Paquette 260 (CANL); Le Portage Trail midway between south sector trailhead and junction with La Vallee Trail, 28.viii.2018, lichenicolous on Pertusaria sp., H. Paquette 362 (CANL); Les Lacs Trail between trailhead off QC-197 and the first lookout, N side of trail, wet Thuja occidentalis stand with some small Abies balsamea, shaded and humid, 2.ix.2018, H. Paquette 460 (CANL); $\mathrm{N}$ side of road between $\mathrm{Ch}$. du Portage and Forillon National Park Operations Centre, exposed Thuja occidentalis swamp, 3.ix.2018, H. Paquette 477 (CANL).

†Stenocybe flexuosa Selva \& Tibell

Specimen examined. - CANADA. QUEBEC. M.R.C. La Côte-de-Gaspé: Forillon National Park, La Vallee Trail, wet Thuja occidentalis stand near trailhead, 14.ix.2018, corticolous on Picea sp., H. Paquette 741 (CANL).

†Stenocybe major Nyl. ex Körb.

Specimens examined. - CANADA. QUEBEC. M.R.C. La Côte-de-Gaspé: Forillon National Park, Les Lacs Trail between trailhead off QC-197 and the first lookout, 21.viii.2018, corticolous on Abies balsamea, H. Paquette 138 (CANL); Le Portage Trail midway between south sector trailhead and junction with La Vallee Trail, corticolous on Abies balsamea, H. Paquette 199 (CANL); Les Lacs Trail at S end of first lake of the Lacs de Penouille (location of backcountry camping shelter), 27.viii.2018, corticolous on Abies balsamea snag and Abies balsamea, H. Paquette 319 (CANL), H. Paquette 320 (CANL); Les Lacs Trail near the backcountry camping shelter at the Lacs de Penouille, 1.ix.2018, corticolous on Abies balsamea snag, H. Paquette 406 (CANL).

†Stenocybe pullatula (Ach.) Stein

Specimen examined. - CANADA. QUEBEC. M.R.C. La Côte-de-Gaspé: Forillon National Park, Les Lacs Trail where it crosses Beaudry Creek, 23.viii.2018, corticolous on Alnus incana spp. rugosa twigs, H. Paquette 212 (CANL). 


\section{B.3 Key to the calicioids of Forillon National Park}

Characters and measurements in the keys are based on material from Forillon examined by the authors, unless otherwise cited.

1. Apothecia stalked

1. Apothecia sessile Cyphelium tigillare

2. Growing on Pertusaria Sphinctrina turbinata

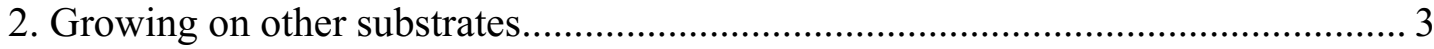

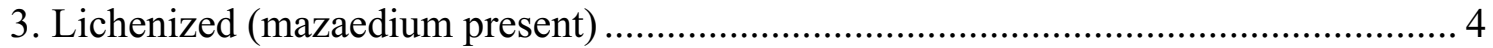

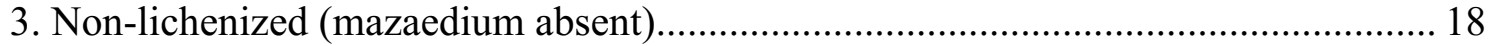

4. Capitula spherical AND thallus greenish and farinose ........................................ 5

4. Not with both spherical capitula and greenish, farinose thallus............................. 6

5. Thallus bright yellow-green; capitula and stalks with yellow pruina....

Chaenotheca furfuracea

5. Thallus greyish-green; capitula and at least the upper stalk with greyish pruina

Chaenotheca gracilenta

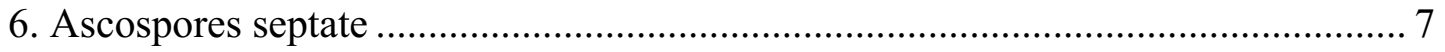

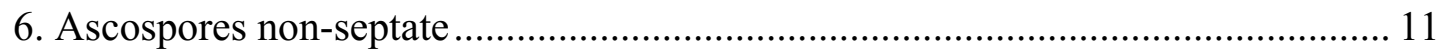

7. Ascospores 1-septate; pruinose or not; thallus endosubstratic ................................. 8

7. Ascospores 1-5-septate, cylindrical or oval (usually both shapes and sizes

represented); excipula with yellow pruina, contrasting with brown mazaedium; thallus endo- or episubstratic

Chaenotheca laevigata

8. Capitula pruinose or pruinose-like

8. Capitula epruinose, bell-shaped; ascospores cracked, without spiral ornamentation Calicium denigratum (Fig. 3.4A-D)

9. Excipula brown, contrasting with black mazaedia; ascospores spirally ornamented ..... Calicium salicinum

9. Excipula with white or yellow pruina; ascospores lacking spiral ornamentation....... 10

10. Excipula with yellow pruina ................................................. Calicium trabinellum

10. Excipula with white pruina ................................................. Calicium glaucellum

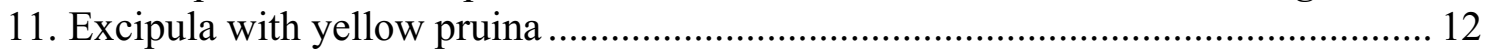

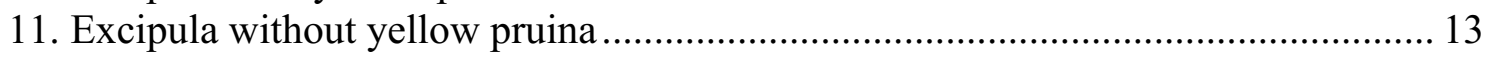

12. Photobiont Trebouxia; thallus episubstratic, bright yellow

Chaenotheca chrysocephala

12. Photobiont Trentepohlia; thallus endosubstratic................ Chaenotheca hispidula

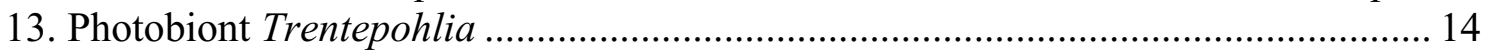

13. Photobiont Stichococcous or Dictyochloropsis ................................................ 15

14. Capitula with white pruina or no pruina; ascospores ca. $3 \mu \mathrm{m}$ in diameter

Sclerophora peronella (Fig. 3.6A-D)

14. Capitula with orange pruina; ascospores ca. $5.5 \mu \mathrm{m}$ in diameter.

Sclerophora coniophaea (Fig. 3.5A-D)

15. Photobiont Dictyochloropsis. Chaenotheca brunneola 
15. Photobiont Stichococcous .

16. Thallus well-developed and verrucose, greenish-grey, PD- Chaenotheca trichialis

16. Thallus farinose, or endosubstratic, greyish-green, PD+ or PD17

17. Thallus farinose, $\mathrm{PD}+$ red; corticolous Chaenotheca stemonea

17. Thallus endosubstratic; ligniciolous Chaenotheca xyloxena

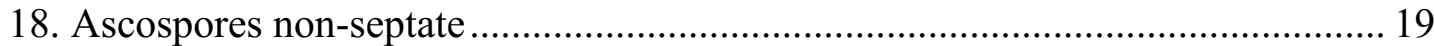

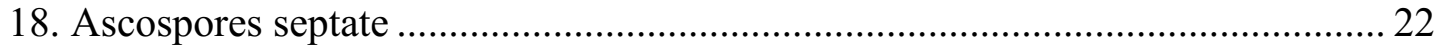

19. Resinicolous; stalks K+ violet .................... Chaenothecopsis oregana (Fig. 3.3A-D)

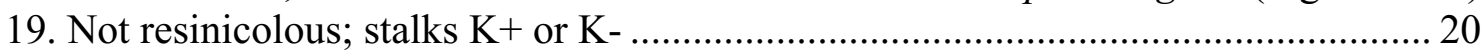

20. Capitula compressed (fan-shaped); ascospores ellipsoidal $>10 \mu \mathrm{m}$ in diameter . 21

20. Capitula not compressed; ascospores football-shaped (pointed ends) $5.5 \mu \mathrm{m}$ in diameter Mycocalicium subtile

21. Corticolous on Betula; excipula with isodiametric hyphae

Phaeocalicium betulinum

21. Corticolous on Alnus viridis ssp. crispa; excipula with periclinally arranged hyphae

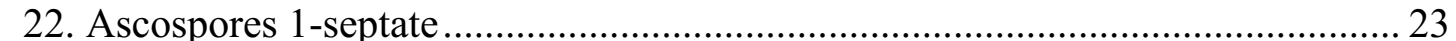

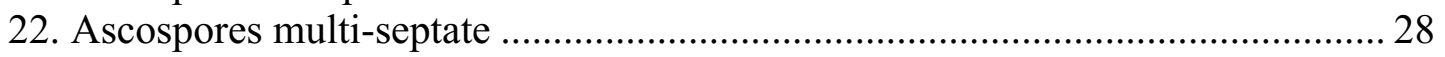

23. Capitula compressed (fan-shaped); corticolous on Betula twigs.

Phaeocalicium flabelliforme

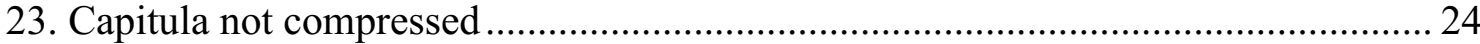

24. Stalks K+ red or red enhanced ................................................................. 25

24. Stalks K-................................................................................................ 26

25. Stalks N+ red/violet; typically forms a white stain on substrate; septa not paler than

ascospore walls

Chaenothecopsis debilis

25. Stalks N-; septa paler than ascospore walls ........................ Chaenothecopsis pusiola

26. Corticolous on Alnus incana ssp. rugosa; ascospores 1-2(3)-septate

Stenocybe pullatula

26. On lignum or Populus; ascospores 1-septate

27

27. Lignicolous; ascospores $<5.5 \mu \mathrm{m}$ long; septa pale ............... Chaenothecopsis pusilla

27. Corticolous on Populus; ascospores 11-16 $\mu \mathrm{m}$ long; septa not paler than walls

Phaeocalicium populneum

28. Capitula compressed (fan-shaped); 3-septate; on Betula

Phaeocalicium matthewsianum

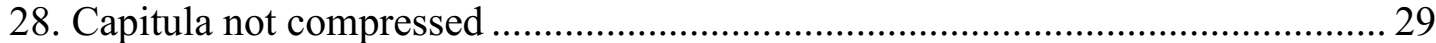

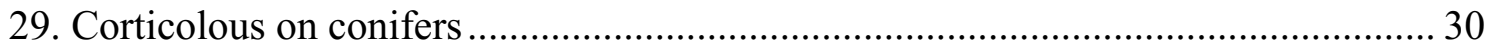

29. Corticolous on Alnus incana ssp. rugosa; ascospores 1-2(3)-septate.

Stenocybe pullatula

30. Corticolous on Abies balsamea; ascospores 3-septate; stalks straight

Stenocybe major

30. Corticolous on Picea; ascospores 3-septate (sometimes with 4- and 5-septate ascospores mixed in according to Selva (2014)); stalks flexuous....Stenocybe flexuosa 


\section{References}

Ahti, T. 1969. Notes on brown species of Parmelia in North America. The Bryologist 72: 233-239.

Ahti, T. and I.M. Brodo. 1981. Cladonia labradorica, sp. nov., and C. kanewskii in Canada. The Bryologist 84: 238-241.

Ahti, T., P.M. Jørgensen, H. Kristinsson, R. Moberg, U. Søchting and G. Thor. Eds. 2007. Nordic Lichen Flora Vol. 3. Nordic Lichen Society, Uppsala. 219 pp.

Allen, J.L. and J.C. Lendemer. 2015a. Japewiella dollypartoniana, a new widespread lichen in the Appalachian Mountains of eastern North America. Castanea 80(1): 59-65.

Allen, J.L. and J.C. Lendemer. 2015b. Fungal conservation in the USA. Endangered Species Research 28: 33-42.

Allen, J.L. and J.C. Lendemer. 2016a. Quantifying the impacts of sea-level rise on coastal biodiversity: a case study on lichens in the mid-Atlantic Coast of eastern North America. Biological Conservation 202: 119-126.

Allen, J.L. and J.C. Lendemer. 2016b. Climate change impacts on endemic, highelevation lichens in a biodiversity hotspot. Biodiversity Conservation 25: 555568.

Allen, J.L. and R.T. McMullin. 2015. Chaenotheca balsamconensis, a new calicioid lichen on Trichaptum abietinum from North America that is benefiting from widespread conifer fatalities. Bryologist 118(1): 54-58.

Allen, J.L., S.K. McKenzie, R.S. Sleith, and S.E. Alter. 2018. First genome-wide analysis of the endangered, endemic lichen Cetradonia linearis reveals isolation by distance and strong population structure. American Journal of Botany 105(9): 1556-1567.

Anderson, F. 2007. An assessment of the status of cyanolichens in Nova Scotia. Evansia 24(2): 23-24.

Anderson Stewart, C.R., J.C. Lendemer, K.G. Keepers, C.S. Pogoda, N.C. Kane, C.M. McCain and E.A. Tripp. 2018. Lecanora markjohnstonii (Lecanoraceae, lichenized Ascomycetes), a new sorediate crustose lichen from the southeastern United States. The Bryologist 121(4): 498-512.

Atwood, Margaret. 1988. Cat's Eye. McClelland-Bantam, Inc., Toronto. 445 pp. 
Balmford, A., P. Crane, A. Dobson, R.E. Green, and G.M. Mace. 2005. The 2010 challenge: data availability, information needs and extraterrestrial insights. Philosophical Transactions of the Royal Society B 360: 221-228.

Brodo I.M. and D.L. Hawksworth. 1977. Alectoria and allied genera. Opera Botanica 42: $1-164$.

Brodo, I.M. and N.A. Sloan. 2005. Lichen zonation on coastal rocks in Gwaii Haanas National Park Reserve, Haida Gwaii (Queen Charlotte Islands), British Columbia. Canadian Field-Naturalist 118: 405-424.

Brodo, I.M., S.D. Sharnoff and S. Sharnoff. 2001. Lichens of North America. Yale University Press, New Haven. 795 pp.

Brodo, I.M., R.C. Harris, W. Buck, J.C. Lendemer and C. Lewis. 2013. Lichens of the Bruce Peninsula, Ontario: Results from the 17th Tuckerman Workshop, 18-22 Sept. 2008. Opuscula Philolichenum 12: 198-232.

Brummitt, R.K., and C.E. Powell. 1996. Authors of Plants Names. Royal Botanical Gardens, Kew. 732 pp.

Büdel B. and O.L. Lange. 1991. Water Status of green and blue-green phycobionts in lichen thalli after hydration by water vapor uptake: do they become turgid? Plant Biology 104(5):361-366.

Cameron, R. P. and D.H.S. Richardson. 2006. Occurrence and abundance of epiphytic cyanolichens in protected areas of Nova Scotia, Canada. Opuscula Philolichenum 3: 5-14

Cleavitt, N.L., A.B. Clyne and T.J. Fahey. 2019. Epiphytic macrolichen patterns along an elevational gradient in the White Mountain National Forest, New Hampshire. Journal of the Torrey Botanical Society 146(1): 8-17.

Committee on the Status of Endangered Wildlife in Canada (COSEWIC). 2014. COSEWIC Status Appraisal Summary on the Frosted Glass-whiskers Sclerophora peronella in Canada. Committee on the Status of Endangered Wildlife in Canada, Ottawa. 20 pp.

Consortium of North American Lichen Herbaria (CNALH). 2019. http//:lichenportal.org/portal/index.php. Accessed 16 January 2019.

Costanza, R., R. d'Arge, R, de Groot, S. Farber, M. Grasso, B. Hannon, K. Limburg, S. Naeem, R.V. O'Neill, J. Paruelo, R.G. Raskin, P. Sutton and M. van den Belt. 1997. The value of the world's ecosystem services and natural capital. Nature 387: 253-260. 
Culberson, C.F. and H. Kristinsson.1970. A standardized method for the identification of lichen products. Journal of Chromatography 46: 85-93.

Degelius, G.N. 1941. Contributions to the Lichen flora of North America II. The lichen flora of the great smoky mountains. Arkiv för Botanik 30(3): 1-80.

Dodge, C.W. 1926. Lichens of the Gaspé Peninsula, Québec. Rhodora 28: 157-161, $205-$ 207, 225-232.

Douglas, G.W. and D.H. Vitt. 1976. Moss-lichen flora of St. Elias-Kluane Ranges, southwestern Yukon. The Bryologist 79: 437-456.

Ecosystem Stratification Working Group. 1995. A national ecological framework for Canada. Agriculture and Agri-Food Canada, Ottawa and Environment Canada, Ottawa. $125 \mathrm{pp}$.

Environment Canada. 1995. Canadian biodiversity strategy: Canada's response to the convention on biological diversity. Minister of Supply and Services Canada, Biodiversity Convention Office, Hull. 86 p.

Environment Canada. 2012. Recovery Strategy for the Woodland Caribou (Rangifer tarandus caribou), Boreal population, in Canada. Species at Risk Act Recovery Strategy Series. Environment Canada, Ottawa. xi $+138 \mathrm{pp}$.

Environment Canada. 2019. Canadian Climate Normals 1981-2010 Station Data - Cap Des Rosiers. http://climate.weather.gc.ca/climate_normals/index_e.html. Accessed January 14, 2019.

Esslinger, T.L. 1973. Chemical and taxonomic studies on some corticolous members of the lichen genus Cetraria in western North America. Mycologia 65: 602-613

Esslinger, T.L. 1977. A chemosystematic revision of the brown Parmeliae. The Journal of the Hattori Botanical Laboratory 42: 1-211.

Esslinger, T.L. 2018. A cumulative checklist for the lichen-forming, lichenicolous and allied fungi of the continental United States and Canada, version 22. Opuscula Philolichenum 17: 6-268.

Freebury, C. E. 2014. Lichens and lichenicolous fungi of Grasslands National Park (Saskatchewan, Canada). Opuscula Philolichenum 13: 102-121.

Giangrande, A. 2003. Biodiversity, conservation, and the 'Taxonomic impediment'. Aquatic Conservation: Marine and Freshwater Ecosystems 13: 451-459.

Global Biodiversity Information Facility (GBIF). 2019. GBIF occurrence download. www.gbif.org. Accessed 14 January 14, 2019. https://doi.org/10.15468/dl.azhbt9 
Government of Canada. 2010. Forillon National Park of Canada: Management plan. Parks Canada, Gaspé. 129 pp.

Government of Canada. 2017. Forillon National Park. https://www.pc.gc.ca/en/pn-np/qc/forillon. Accessed January 14, 2019.

Government of Canada. 2018. Forillon National Park Canada 2017 Year in Review. Parks Canada, Gaspé. 15 pp.

Government of Canada. 2019. Species at Risk Act. https://lawslois.justice.gc.ca/eng/acts/S-15.3/page-1.html. Accessed 14 January 2019.

Gowan, S., and I. M. Brodo. 1988. The lichens of Fundy National Park, New Brunswick, Canada. The Bryologist 91: 255-325.

Goward, T. 1999. The lichens of British Columbia Illustrated keys. Part 2 - Fruticose species. B.C. Ministry of Forests Research Program (Special Report Series no. 9). Crown Publications Queen's Printer for British Columbia, Victoria. 319 pp.

Goward, T. and A. Arsenault. 2000. Cyanolichens and conifers: implications for global conservation. Forest Snow and Landscape Research 75(3): 303-318.

Goward, T. and A. Arsenault. 2018. Calicioid diversity in humid inland British Columbia may increase into the 5th century after stand initiation. The Lichenologist 50: $555-569$.

Goward, T., O. Breuss, B. Ryan, B. McCune, H. Sipman and C. Scheidegger. 1996. Notes on the lichens and allied fungi of British Columbia. III. The Bryologist 99: 439-449.

Hale, M.E., Jr. 1974. The Biology of Lichens. Second Edition. Contemporary Biology, Edward Arnold, London. $181 \mathrm{pp}$.

Hale, M. E., Jr. 1987. A monograph of the lichen genus Parmelia Acharius sensu stricto (Ascomycotina, Parmeliaceae). Smithsonian Contributions to Botany 74: 1-55.

Hardman, A., D. Stone and S.B. Selva. 2017. Calicioid lichens and fungi of the Gifford Pinchot and Okanogan-Wenatchee National Forests in Washington, U.S.A. Opuscula Philolichenum 16: 1-14.

Haughland, D.L. and M. Martel. 2016. Chaenothecopsis oregana new to Canada. Evansia 33: 34-39.

Hawksworth, D.L. and D.J. Hill. 1984. The Lichen-Forming Fungi. Blackie \& Son, Ltd., Glasgow. 158 pp. 
Hawksworth, D. L., P.M. Kirk, B.C. Sutton and D.N. Peglers. 1995. Ainsworth \& Bisby's Dictionary of the Fungi. CAB International, Wallingford. xii +616 pp.

Henderson, A. 2000. Literature on air pollution and lichens XLIX. The Lichenologist 32:89-102.

Hinds, J.W. and P.L. Hinds. 2007. The Macrolichens of New England. The New York Botanical Garden Press, Bronx. 584 pp.

Hinds, J.W., P.L. Hinds, L.G. Biazrov and J.D. Eckhoff. 1998. First United States Record of the Lichen Parmelia fertilis. Northeastern Naturalist 5(1): 21-23.

Hoefs, M and J.W. Thomson. 1972. Lichens from the Kluane Game Sanctuary, S.W. Yukon Territory. Canadian Field-Naturalist 86: 249-252.

Hrapko, J.O. and G.H. La Roi. 1978. The alpine tundra vegetation of Signal Mountain, Jasper National Park. Canadian Journal of Botany 56: 309-332.

John, E.A. 1989. The saxicolous lichen flora of Jonas Rockslide, Jasper National Park, Alberta. The Bryologist 92: 105-111.

Kärnefelt, I. 1979. The brown fruticose species of Cetraria. Opera Botanica 46: 1-150.

Laflamme-Levesque, M., J.M. Perron, and L. Jobin. 1979. Etude des lichens appartenant aux generes Bryoria, Alectoria et Ramalina dans les foyers d'infestation de Lambdina fiscellaria fiscellaria (Guen.) a l'ile d'Anticosti. Naturaliste Canadien 106: 505-510.

Lamb, I.M. 1954. Lichens of Cape Breton Island, Nova Scotia. Annual Report of the National Museum of Canada, Bulletin 132: 239-313.

Lendemer, J.C., R.C. Harris and E.A. Tripp. 2013. The Lichens and Allied Fungi of Great Smoky Mountains National Park: An Annotated Checklist with Comprehensive Keys. Memoirs of The New York Botanical Garden 104: 1-152.

Lendemer, J.C., J.R. Hoffman and J.W. Sheard. 2019. Rinodina brauniana (Physciaceae, Teloschistales), a new species with pseudoisidia from the southern Appalachian Mountains of eastern North America. The Bryologist 122(1): 111-121.

Lumbsch, H.T., T. Ahti, S. Altermann, G. Amo de Paz, A. Aptroot, U. Arup, A. Bárcenas Peña, P.A. Bawingan, M.N. Benatti, L. Betancourt, C.R. Björk, K. Boonpragob, M. Brand, F. Bungartz, M.E.S. Cáceres, M. Candan, J.L. Chaves, P. Clerc and R. Common. 2011. One hundred new species of lichenized fungi: a signature of undiscovered global diversity. Phytotaxa 18: 1-127. 
Malcolm, W.M. and D.J. Galloway. 1997. New Zealand Lichens. Checklist, Key, and Glossary. Museum of New Zealand Te Papa Tongarewa, Wellington. 192 pp.

McCune, B. and L. Geiser. 2009. Macrolichens of the Pacific Northwest. Second Edition. Oregon State University Press, Corvallis. 464 pp.

McMullin, R.T. 2009. Lichens of Kejimkujik National Park and National Historic Site, Nova Scotia, Canada (Provisional List). Opuscula Philolichenum 7: 71-78.

McMullin, R.T. 2012. New and interesting lichens from Kejimkujik National Park and National Historic Site, Nova Scotia, Canada. Opuscula Philolichenum 11: 52-59.

McMullin, R.T. 2015. The lichens of Prince Edward Island, Canada: a second checklist, with species ranked for conservation status. Rhodora 117(972): 454-484.

McMullin, R.T. 2018. New and interesting lichens and allied fungi from British Columbia, Nova Scotia, Nunavut, Ontario, Prince Edward Island, and Quebec, Canada. Opuscula Philolichenum 17: 275-292.

McMullin, R.T. and A. Arsenault. 2016. The calicioids of Newfoundland, Canada. Opuscula Philolichenum 15: 92-104.

McMullin, R.T., and B.C. Dorin. 2016. The Chic-Choc Mountains are the last southern refuge for Arctic lichens in eastern North America. Arctic Science 2:183-193.

McMullin, R.T. and J.C. Lendemer. 2016. Lichens and allied fungi of Awenda Provincial Park, Ontario: diversity and conservation status. American Midland Naturalist 176: 1-19.

McMullin, R.T. and J.C. Lendemer. 2013. Lichen biodiversity and conservation status in the Copeland Forest Resources Management Area: a lichen-rich second growth forest in southern Ontario. Canadian Field Naturalist 127: 240-254.

McMullin, R.T. and Y.F. Wiersma. 2017. Lichens and allied fungi of Salmonier Nature Park, Newfoundland. Journal of the Torrey Botanical Society 144(3): 357-369.

McMullin, R.T. and Y.F. Wiersma. 2019. Out with OLD growth, in with ecological continNEWity: new perspectives on forest conservation. Frontiers in Ecology and the Environment 17(3):176-181.

McMullin, R.T., P.N. Duinker, R.P. Cameron, D.H.S. Richardson and I.M. Brodo. 2008. Lichens of coniferous old-growth forests of southwestern Nova Scotia, Canada. Diversity and present status. The Bryologist 111: 620-637. 
McMullin, R.T., S.B. Selva, J.R. Maloles and S.G. Newmaster. 2012. Calicium denigratum (Vain.) Tibell, a new lichen record for North America. North America Fungi 7: 1-5.

McMullin, R.T., D. Ure, M. Smith, H. Clapp, and Y.F. Wiersma. 2017a. Ten years of monitoring air quality and ecological integrity using field-identifiable lichens at Kejimkujik National Park and National Historic Site in Nova Scotia, Canada. Ecological Indicators 81: 214-221.

McMullin, R.T., J. Gagnon, F. Anderson, W.R. Buck, S.R. Clayden, B.C. Dorin, A. Fryday, J.G. Guccion, R.C. Harris, J. Hinds, C. Isabel, D. Ladd, E. Lay, J.C. Lendemer, J.R. Maloles, C. Roy and D.P. Waters. 2017b. One hundred new provincial, national, and continental lichen and allied fungi records from parc national de la Gaspésie, Québec, Canada. Northeastern Naturalist 24(4): 446-466.

McMullin, R.T., J.R. Maloles, S.B. Selva and S.G. Newmaster. 2018. A synopsis of Chaenotheca in North America, including a new species from southern Ontairo, C. selvae, supported by morphometric analyses. Botany 96: 547-553.

Merinero, S., M. Rubio-Salcedo, G. Aragón and I. Martínez. 2014. Environmental factors that drive the distribution and abundance of a threatened cyanolichen in southern Europe: a multi-scale approach. American Journal of Botany 101(11): 1876-1885.

Monastersky, R. 2014. Life - a status report. Nature 516(7530): 159-161.

National Air Photo Library (NAPL). 1966. A19526 photo 049-051. Ottawa.

Nash III, T.H. Ed. 2008. Lichen Biology (2nd ed.). Cambridge University Press, New York. $486 \mathrm{pp}$.

NatureServe. 2019. NatureServe Explorer ${ }^{\circledR}$ an online encyclopedia of life. NatureServe, Arlington, Virginia. http://www.natureserve.org/conservation-tools/data-mapstools/natureserve-explorer. Accessed June 26, 2019.

Newmaster, S.G., R.J. Belland, A. Arsenault, D.H. Vitt and T.R. Stephens. 2005. The ones we left behind: Comparing plot sampling and floristic habitat sampling for estimating bryophyte diversity. Diversity and Distributions 11: 57-72.

Nieboer, E., D.H.S. Richardson and F.D. Tomassini. 1978. Mineral uptake and release by lichens: an overview. The Bryologist 81(2): 226-246.

Orange, A. 2008. Saxicolous Lichen and Bryophyte Communities in Upland Britain. Joint Nature Conservation Committee (JNCC) Report No. 404, Peterborough. 324 pp.

Orange, A., P.W. James and F.J. White. 2010. Microchemical Methods for the Identification of Lichens (2nd printing). British Lichen Society, London. 101 pp. 
Otálora, M.A., P.M. Jørgensen and M. Wedin. 2014. A revised generic classification of the jelly lichens, Collemataceae. Fungal Diversity 64: 275-293.

Otte, V., T.L. Esslinger and B. Litterski. 2005. Global distribution of the European species of the lichen genus Melanelia Essl. Journal of Biogeography 32: 12211241.

Parks Canada. 1983. The rare plants of Forillon National Park. Canadian Government Publishing Centre, Ottawa. 51 pp.

Petersen, K., L.M. Calabria, J.E.D. Miller, J. Brown-Clay, L. Hynson, T. Steen, K. Johnston, A. Ulbrich, E. Chandler, M. Miller and J. Villella. 2017. Substrate age influences species richness and community composition of calicioid lichens and fungi on wooden buildings. The Bryologist 120: 19-24.

Piercey-Normore, M.D., I.M. Brodo and C. Deduke. 2016. Lichens on the Hudson Bay Lowlands: a long-term survey in Wapusk National Park, Manitoba. The Lichenologist 48(5): 581-592.

Pike, L.H. 1978. The importance of epiphytic lichens in mineral cycling. The Bryologist 81: 247-257.

Pimm, S.L., G.J. Russell, J.L. Gittleman and T.M. Brooks. 1995. The future of biodiversity. Science 269(5222): 347-350.

Powell, G.V.N., J. Barborak, and M.S. Rodriguez. 2000. Assessing representativeness of protected natural areas in Costa Rica for conserving biodiversity: a preliminary gap analysis. Biological Conservation 93: 35-41.

Purvis, O.W., B.J. Coppins, D.L. Hawksworth, P.W. James and D.M. Moore. 1992. The lichen flora of Great Britain and Ireland. Natural History Museum, London. 710 pp.

QGIS Development Team. 2019. QGIS Geographic Information System. Open Source Geospatial Foundation Project. http://qgis.osgeo.org. Accessed 16 January 2019.

Richardson, D.H.S 1992. Pollution monitoring with lichens. Richmond Publishing, Slough. 76 pp.

Rikkinen, J. 2003. New resinicolous ascomycetes from beaver scars in western North America. Annales Botanici Fennici 40: 443-450

Roed, M.A. 1979. Geomorphologic analysis of Forillon National Park, Quebec, Canada. Maritime Sediments 15: 47-54. 
Rose, F. 1974. The epiphytes of oak. In: M.G. Morris and F.H. Pering, (Eds.), The British Oak: Its History and Natural History. Conference Reports 14. Botanical Society of the British Isles, Faringdon. pp. 250-273.

Rose, F. 1976. Lichenological indicators of age and environmental continuity in woodlands. In: D.H. Brown, D.L. Hawkesworth and R.H. Baily (eds.). Systematics Association Special Volume No. 8, "Lichenology: Progress and Problems.” Academic Press, London. pp. 279-307.

Scheidegger, C. and S. Werth. 2009. Conservation strategies for lichens: insights from population biology. Fungal Biology Reviews 23: 55-66.

Schram, L.J., C. Wagner, R.T. McMullin and M. Anand. 2015. Lichen communities along a pollution gradient 40 years after decommissioning of a $\mathrm{Cu}-\mathrm{Ni}$ smelter. Environmental Science and Pollution Research 22(12): 9323-9331.

Schwendener, S. 1867. Über die wahre Nature der Flechtengonidien. Verhandlungen der schweizerischen naturforschenden Gesellschaft, 57: 9-11.

Selva, S.B. 1994. Lichen diversity and stand continuity in the northern hardwoods and spruce-fir forests of northern New England and western New Brunswick. The Bryologist 93: 380-381.

Selva, S.B. 1999. Survey of epiphytic lichens of late successional northern hardwoods forests in northern Cape Breton Island. Cape Breton Highlands National Park and Parks Canada, Ingonish Beach. 53 pp.

Selva, S.B. 2003. Using calicioid lichens and fungi to assess ecological continuity in the Acadian Forest Ecoregion of the Canadian Maritimes. The Forestry Chronicle 79: $550-558$.

Selva, S.B. 2010. New and interesting calicioid lichens and fungi from eastern North America. The Bryologist 113: 272-276.

Selva, S.B. 2013. The calicioid lichens and fungi of the Acadian Forest ecoregion of northeastern North America, I. New species and range extensions. The Bryologist 116: $248-256$.

Selva, S.B. 2014. The calicioid lichens and fungi of the Acadian Forest ecoregion of northeastern North America, II. The rest of the story. The Bryologist 117: 336367.

Selva, S.B. 2016. Calicioid lichens and fungi of Great Smoky Mountains National Park: not a healthy population. Evansia 33(3): 106-122. 
Selva, S.B. and L. Tibell. 1999. Lichenized and non-lichenized calicioid fungi from North America. The Bryologist 102: 377-397.

Shorthouse, D.P. 2010. SimpleMappr, an online tool to produce publication-quality point maps. https://www.simplemappr.net. Accessed 16 January 2019.

Sierk, H.A. 1964. The genus Leptogium in North America north of Mexico. The Bryologist 67(3): 245-317.

Sigouin, D., J.-P. Tremblay, S. Lavoie and M. Côté. 2013. Protocole de suivi de la vegetation en relation avec l'abondance de la population d'orignaux au parc national du Canada Forillon. Agence Parcs Canada, Service de la conservation des écosystèmes, Parc national du Canada Forillon, Gaspé. 25 pp.

Sirois, L., F. Lutzoni, and M.M. Grandtner. 1988. Les lichens sur serpentine et amphibolite du plateau du mont Albert, Gaspésie, Québec. Canadian Journal of Botany 66:851-862.

Smith, A.L. 1921. A Handbook of the British Lichens. British Museum, London. 160 pp.

Smith, D.C. and A.E. Douglas. 1987. The Biology of Symbiosis. Contemporary Biology, Edward Arnold, London. 302 pp.

Spribille, T., S. Pérez-Ortega, T. Tønsberg and D. Schirokauer. 2010. Lichens and lichenicolous fungi of the Klondike Gold Rush National Historic Park, Alaska, in a global biodiversity context. The Bryologist 113(3): 439-515.

St-Amour, M. 1985. Forillon National Park the harmony between man, the land and the sea, a guide. Douglas \& McIntyre Ltd., Vancouver. 123 pp.

Stone, D.F., J.W. Hinds, F.L. Anderson and J.C. Lendemer. 2016. A revision of the Leptogium saturninum group in North America. The Lichenologist 48(5): 387421.

Thomson, J.W. 1984. America Arctic Lichens 1. The Macrolichens. Columbia University Press, New York, 504 pp.

Thomson, J.W. 1997. American Arctic Lichens 2. The Microlichens. The University of Wisconsin Press, Madison. 675 pp.

Thoreau, H.D. 1851. Journal entry of December 31, 1851. In: Damion Searls (Ed.), The Journal 1837-1861 Henry David Thoreau. New York Review Books, New York. pp 103.

Tibell, L. 1992. Crustose lichens as indicators of forest continuity in boreal coniferous forests. Nordic Journal of Botany 12: 427-450. 
Tibell, L. 1996. Caliciales. Flora Neotropica 69: 1-79.

Tibell, L. 1999. Caliciales. Nordic Lichen Flora 1: 20-71.

Timoney, K.P. and A.L. Robinson. 1992. Old-growth white spruce and balsam poplar forests of the Peace River lowlands, Wood Buffalo National Park, Canada: development, structure, and diversity. Forest Ecology and Management 81: 179196.

Tripp, E.A and J.C. Lendemer. 2018. Twenty-seven modes of reproduction in the obligate lichen symbiosis. Brittonia 70: 1-14.

Tripp, E.A., J.C. Lendemer, A. Barberán, R.R. Dunn and N. Fierer. 2016. Biodiversity gradients in obligate symbiotic organisms: exploring the diversity and traits of lichen propagules across the United States. Journal of Biogeography 43: 16671678.

Trombulak, S.C., M.G. Anderson, R.F. Baldwin, K. Beazley, J.C. Ray, C. Reining, G. Woolmer, C. Bettigole, G. Forbes and L. Gratton. 2008. The Northern Appalachian/Acadian Ecoregion: Priority locations for conservation action. Two Countries, One Forest Special Report No. 1: 1-58.

Tuovila, H., P. Larsson and J. Rikkinen. 2011. Three resinicolous North American species of Mycocaliciales in Europe with a re-evaluation of Chaenothecopsis oregana Rikkinen. Karstenia 51: 37-49.

Tuovila, H., J. Rikkinen and H.S. Huhtinen. 2012. Nomenclatural corrections in calicioid fungi. Karstenia 52: 73-74.

Velmala, S., L. Myllys, T. Goward, H. Holien and P. Halonen. 2014. Taxonomy of Bryoria section Implexae (Parmeliaceae, Lecanoromycetes) in North America and Europe, based on chemical, morphological and molecular data. Annales Botanici Fennici 51: 345-371.

Wetmore, C.M. 1960. The lichen genus Nephroma in North and Middle America. Publication of the Museum, Michigan State University, Biology Series 1(11): 369-452.

White, P.B., S.L.van de Gevel and P.T. Soule. 2012. Succession and disturbance in an endangered red spruce-Fraser fir forest in the southern Appalachian Mountains, North Carolina, USA. Endangered Species Research 18: 17-25.

Whittaker, R.H. 1956. Vegetation of the Great Smoky Mountains. Ecological Monographs 26: 1-80. 